TURNING ABOUND THE POWER DISTRIBUTION SECTOR

Learnings and Best Practices from Reforms 


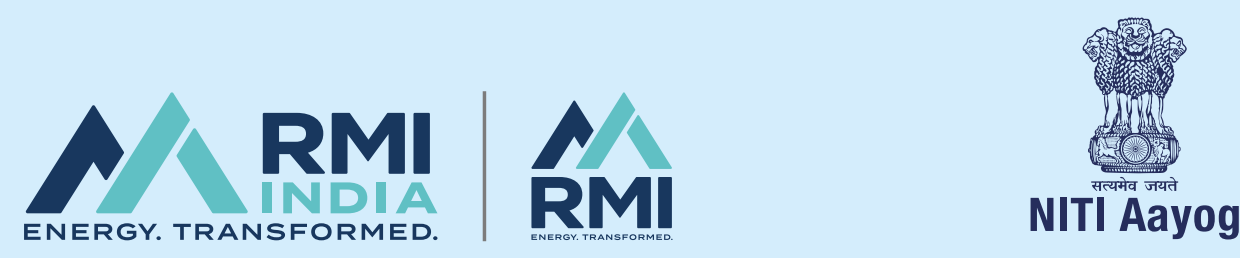

\section{TURNING AROUND}

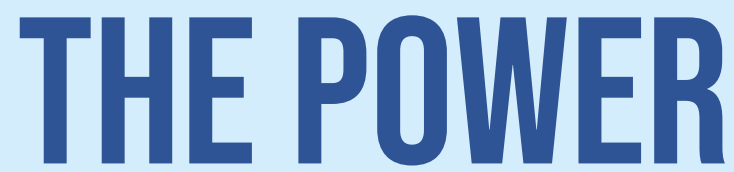

DISTRIBUTION SECTOR

Learnings and Best Practices from Reforms

August 2021 


\section{Suggested Citation}

Prasanth Regy, Rakesh Sarwal, Clay Stranger, Garrett Fitzgerald, Jagabanta Ningthoujam, Arjun Gupta, Nuvodita Singh. 2021. Turning Around the Power Distribution Sector: Learnings and Best Practices from Reforms. NITI Aayog, RMI, and RMI India.

ISBN: 978-81-949510-3-2

DOI: 10.31219/osf.io/xd2he

\section{Available at:}

NITI Aayog: https://www.niti.gov.in/

RMI: https://rmi.org/insight/turning-around-the-power-distribution-sector

RMI India: https://rmi-india.org/insight/turning-around-the-power distribution-sector

\section{Disclaimer}

The views expressed in this document are those of the authors. They do not necessarily reflect the views and policies of NITI Aayog, RMI, RMI India, or of the reviewers. 


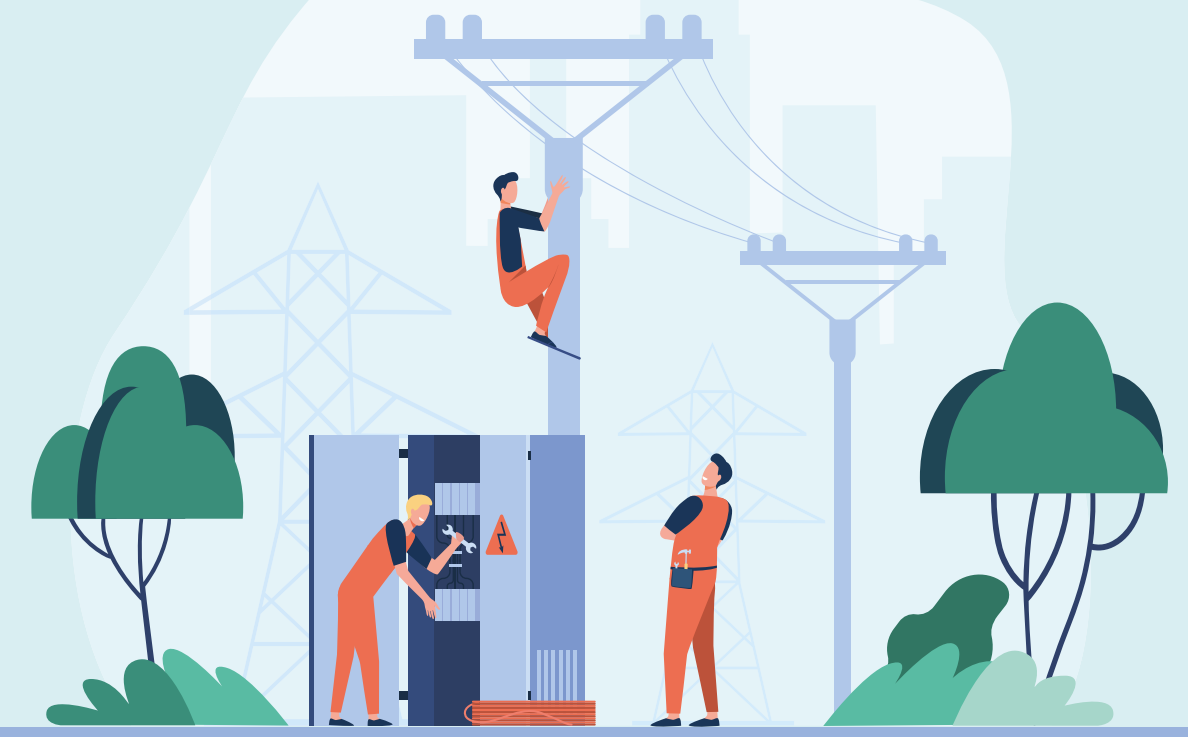

\section{Contents}

About Us

Acknowledgements

Foreword

vii

Preface

List of Abbreviations

Executive Summary

$x v i i$

1. Introduction 6

$\begin{array}{lll}1.1 & \text { Background } & 6\end{array}$

1.2 Status of Discoms 7

1.3 Distribution Sector Reforms 12

2. Structural Reforms 19

2.1 Ownership Models 19

2.2 Vertical Unbundling 24

2.3 Horizontal Unbundling 24

3. Regulatory Reforms $\quad 27$

3.1 Role of State Regulatory Commissions 27

3.2 Direct Benefit Transfer 28

4. Operational Reforms 31

4.1 Power Procurement Cost Optimisation 31 
4.2 Metering and Billing 33

4.3 Improving Collection Efficiency 35

4.4 Demand-side Flexibility and the Role of Dynamic Tariff 36

4.5 Upgrading Distribution Infrastructure 38

4.6 Agricultural Demand Management 39

5. Solutions for RE Integration 40

5.1 Regional Interconnection and Balancing 40

5.2 Renewable Purchase Obligations 42

5.3 Advanced RE Forecasting 42

5.4 Decentralised Renewable Energy 44

6. Managerial Reforms $\quad 48$

6.1 Vision and Leadership 48

6.2 Customer Facilitation 49

6.3 Employee Incentives and Worker Protection 49

7. Best Practices and Recommendations 50

7.1 Review of Best Practices 50

7.2 Recommendations 54

7.3 Conclusion 57

$\begin{array}{ll}\text { 8. Appendix } & 59\end{array}$

Appendix 1: Discom Profitability 2009-10 to 2018-19 (Including Tariff Subsidy Received, in ₹ Crore) 60

Appendix 2: Discom ACS-ARR Gap 2008-09 to 2018-19 61

Appendix 3: Operational and Financial Positions of Discoms in Indian States for 2018-19 62

Appendix 4: Discom Performance Analysis for FY 201963

9. References 65 


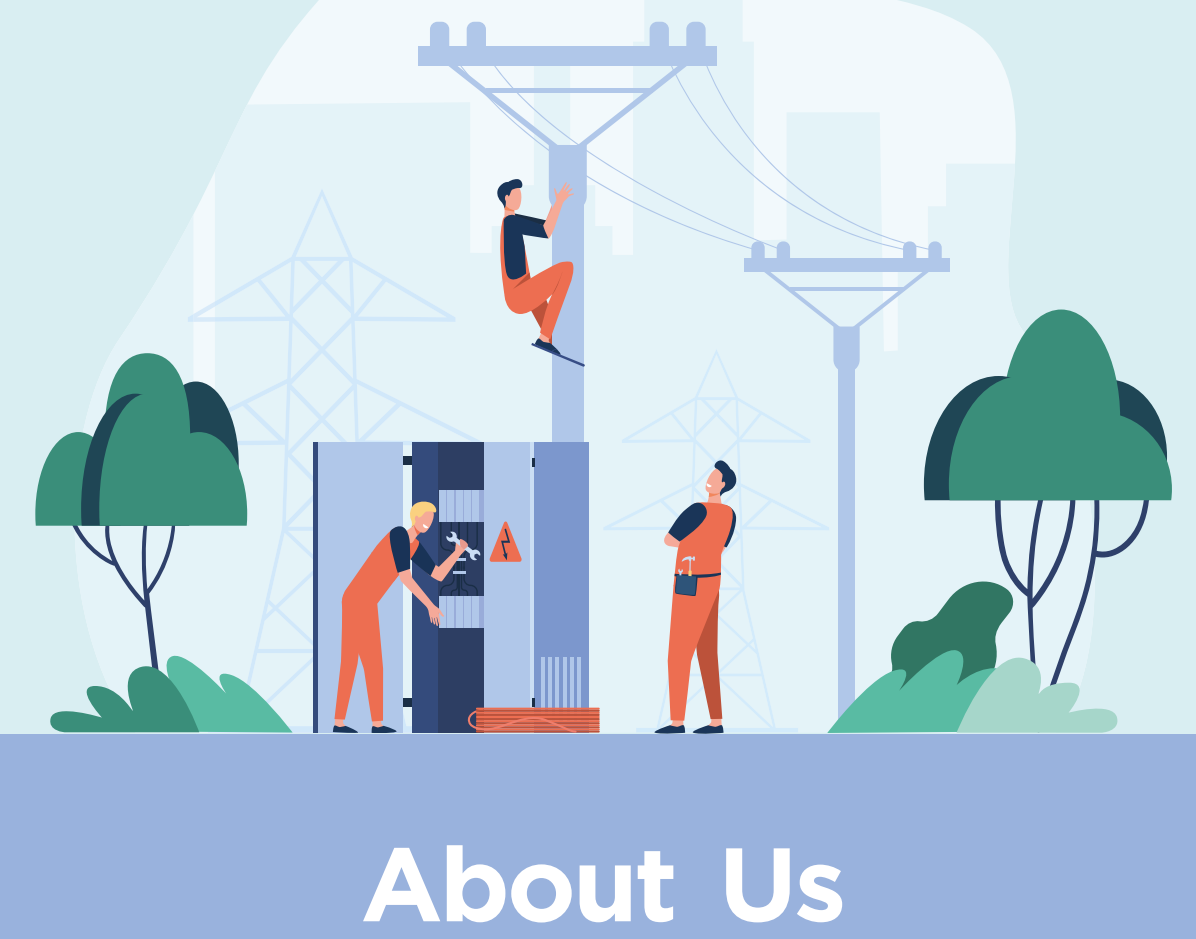

\section{ABOUT NITI AAYOG}

The National Institution for Transforming India (NITI Aayog) was formed via a resolution of the Union Cabinet on January 1, 2015. NITI Aayog is the premier policy 'Think Tank' of the Government of India, providing both directional and policy inputs. While designing strategic and long-term policies and programmes for the Government of India, NITI Aayog also provides relevant technical advice to the Centre and States. The Government of India, in keeping with its reform agenda, constituted the NITI Aayog to replace the Planning Commission instituted in 1950. This was done in order to better serve the needs and aspirations of the people of India. An important evolutionary change from the past, NITI Aayog acts as the quintessential platform of the Government of India to bring States to act together in national interest, and thereby fosters Cooperative Federalism.

\section{ABOUT RMI}

$\mathrm{RMI}$ is an independent nonprofit founded in 1982-transforms global energy use to create a clean, prosperous, and secure low-carbon future. It engages businesses, communities, institutions, and entrepreneurs to accelerate the adoption of market-based solutions that cost-effectively shift from fossil fuels to efficiency and renewables. RMI has been supporting India's mobility and energy transformation since 2016. 


\section{ABOUT RMI INDIA}

RMI India is an independent think tank. RMI India takes inspiration from and collaborates with RMI, a 40-year-old nongovernmental organisation. RMI India's mission is to accelerate India's transition to a clean, prosperous, and inclusive energy future.

\section{AUTHORS}

\section{NITI Aayog}

- Prasanth Regy

- Rakesh Sarwal

RMI

- Clay Stranger

- Garrett Fitzgerald

\section{RMI India}

- Jagabanta Ningthoujam

- $\quad$ Arjun Gupta

- Nuvodita Singh

\section{CONTACTS:}

niti.gov.in/content/contact-us indiainfo@rmi.org 


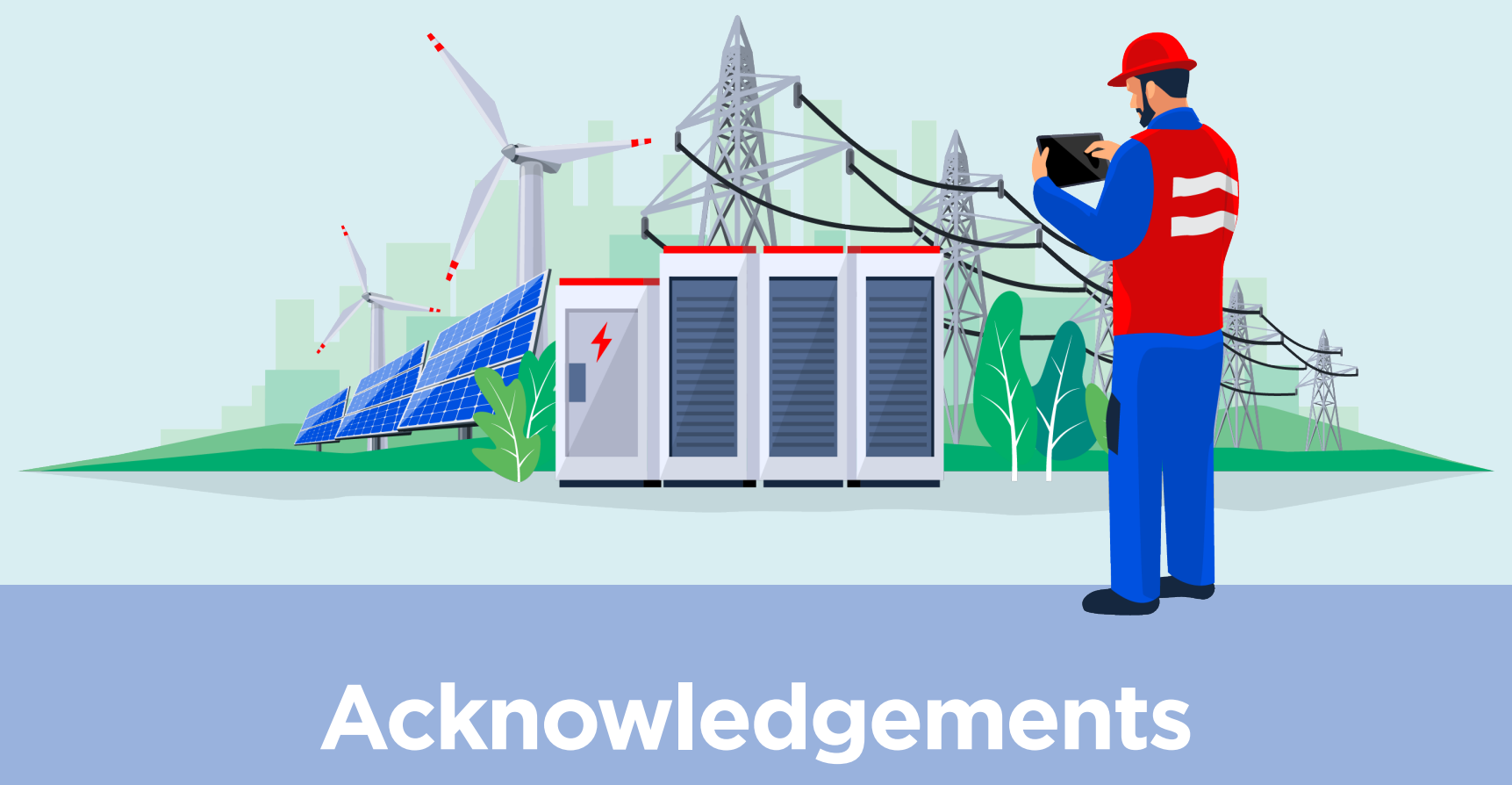

The report benefited greatly from the comments and feedback of Dr Rajiv Kumar, Vice Chairman; Dr V. K. Saraswat, Member; Amitabh Kant, CEO; Rajnath Ram, Advisor; Manoj Upadhyay, Deputy Advisor (all at NITI Aayog); and Akshima Ghate (RMI India).

The authors are grateful to the following organisations and individuals who provided valuable feedback during the review phase: Ministry of Power (MoP), Ministry of New and Renewable Energy (MNRE), Pankaj Batra (SARI/EI, IRADe), AK Saxena (TERI), Ann Josey (Prayas Energy Group), Samanwit Biswal and Vaishali Mishra (Smart Power India), Prof. R Srikanth and Soumya Deep Das (National Institute of Advanced Studies), and Profs. Kaveri K Iychettira and Abhishek Malhotra (School of Public Policy, Indian Institute of Technology Delhi).

The authors are also thankful to Indrani Dasgupta (NITI Aayog) for her detailed editing and revision of the manuscript. 


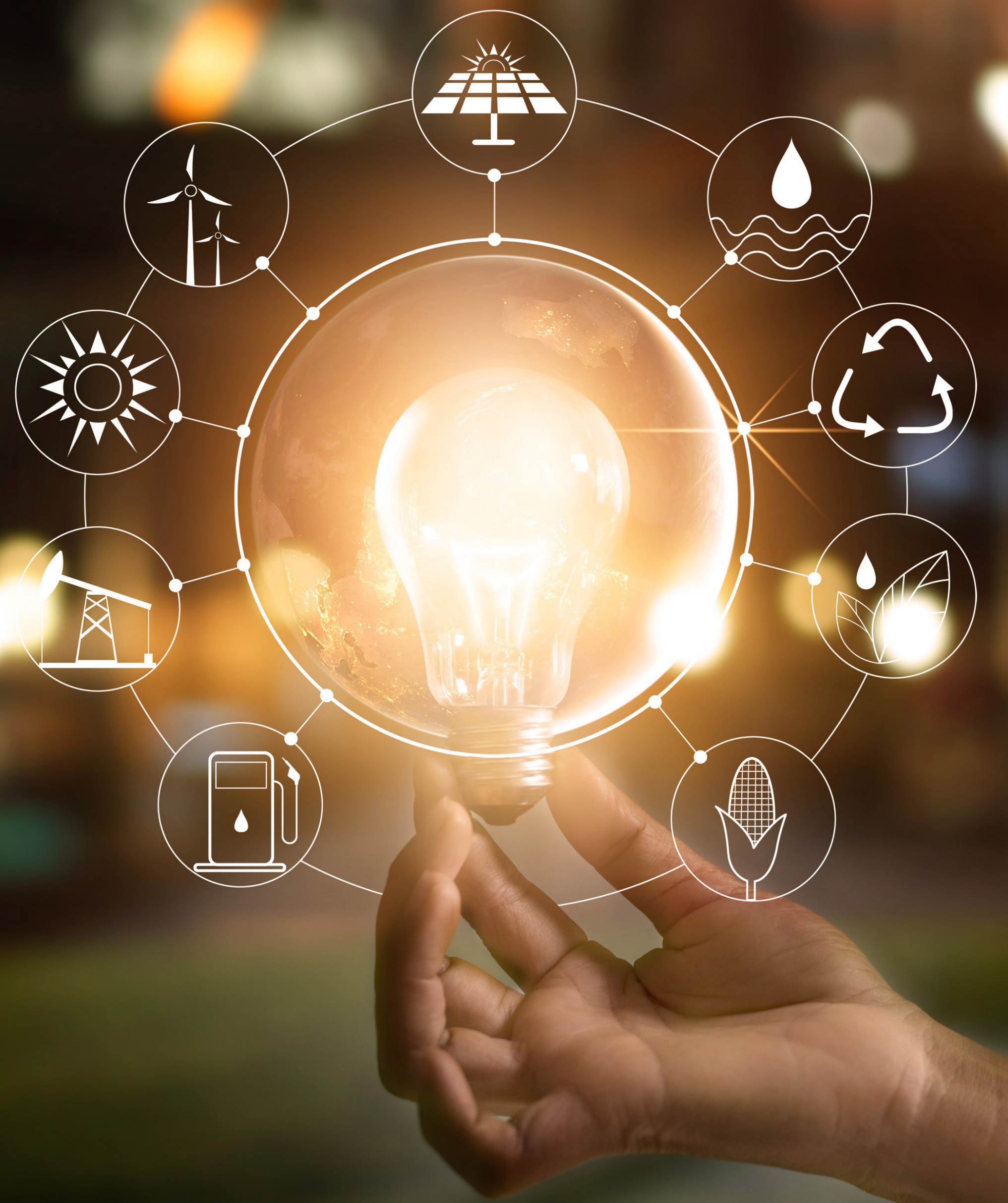




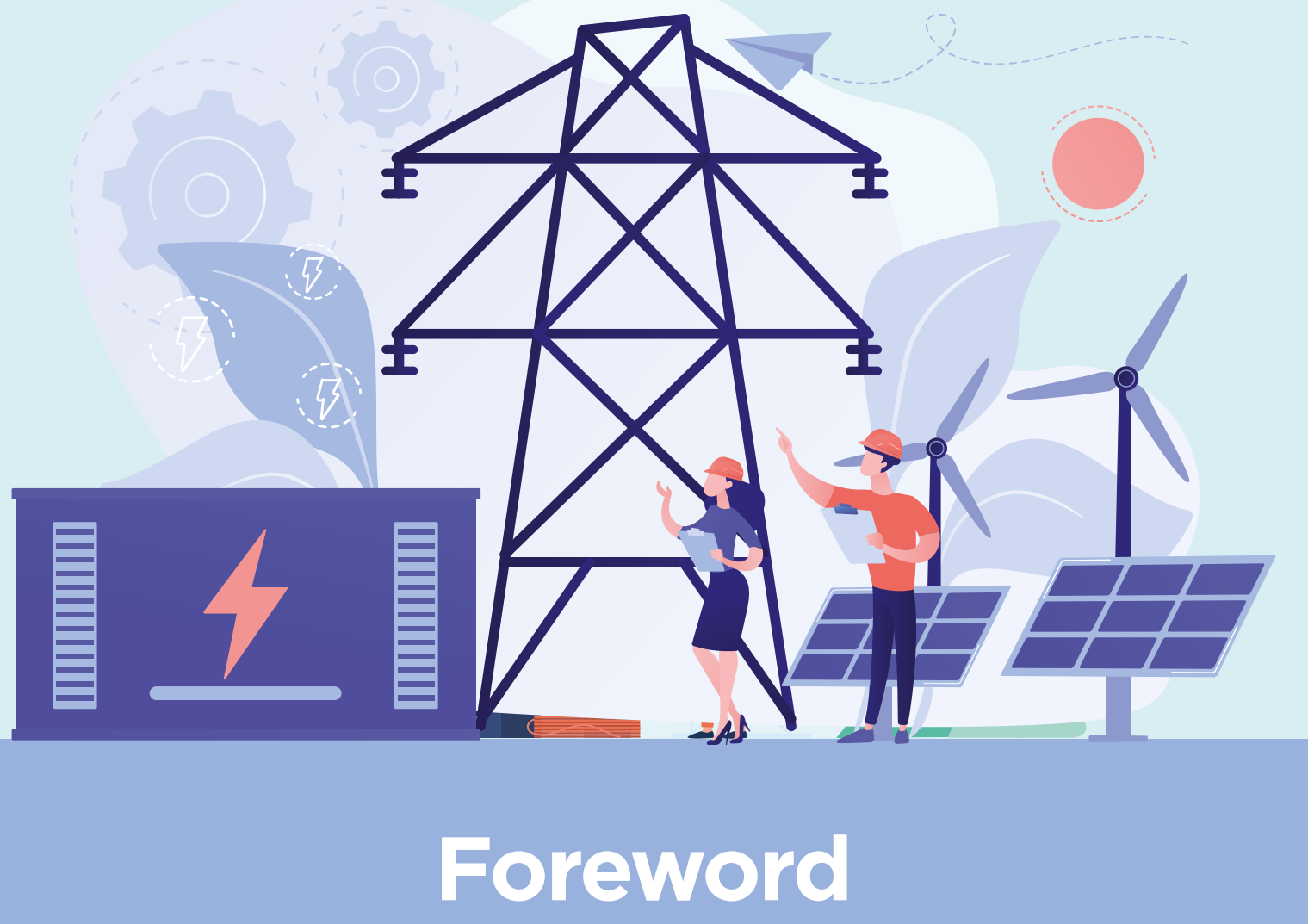

The past few years have seen major developments in the power distribution sector in India. We have now achieved universal access to electricity.

However, power distribution continues to be the weakest link in the supply chain of the power sector. Most distribution utilities are making major losses as a consequence of expensive long-term power purchase agreements, poor infrastructure, and inefficient operations, among others. These losses, in turn, prevent them from making the investments required to improve the quality of the power supply and to prepare for the wider penetration of renewable energy. The distribution utilities' inability to pay power generators endangers the financial health of the generators and their lenders, causing a negative domino effect on the economy.

The Electricity Act, 2003, was a milestone in the reform journey. Since then, several states have reformed their distribution sectors along different paths. This Report, prepared as a collaboration between NITI Aayog and Rocky Mountain Institute (RMI), USA, presents a review of the reform efforts in the Indian distribution sector. The Report aims to contextualize learnings and best practices from domestic as well as global experience, to provide a set of options for state governments that are considering further reforms to put their distribution sector on the track to efficiency and profitability.

It is hoped that the Report will be useful to researchers and practitioners in the distribution sector, and particularly to policy makers. I congratulate the Energy Vertical Team of NITI Aayog, and the team at RMI, for bringing out this Report, and I hope it becomes a valuable reference document in the debate on this very important topic.

Dr Rajiv Kumar

Vice Chairman, NITI Aayog 


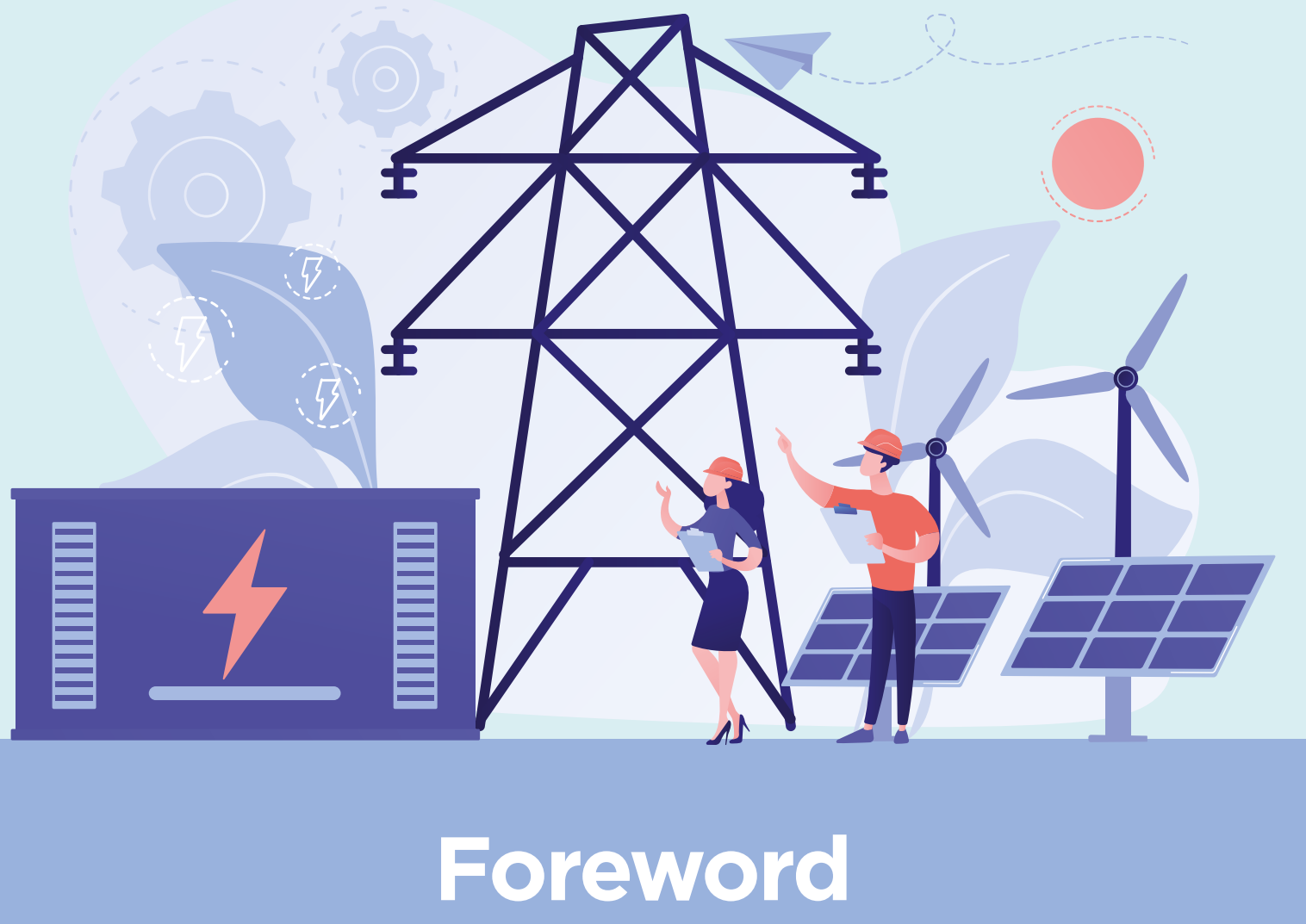

The power sector, globally as well as in India, is undergoing a sea change. This is visible in the increasing deployment of clean renewables and the rising prevalence of gridconnected distributed generation. While these trends create churn and disruption in the power sector, they also create opportunities for new and innovative business models.

These changes will require flexibility throughout the power sector. Most new generation capacity is likely to be renewable. Increased flexibility in generation will be required - both physical (flexible generation, and demand response) and institutional (such as access to markets). The transmission sector will require greater capacity to evacuate power from renewable-rich regions to the rest of the nation. Digitalisation of the grid will enable bidirectional flow of information and power. Utility-scale energy storage, being able to act as load or as supply, will play an important role in enhancing the flexibility of the system.

In India, this transition is all the more challenging because of the poor operational and financial condition of the distribution sector. The distribution companies, as a whole, are loss-making and debt-ridden; consequently, they are not able to invest in better infrastructure, to provide better services to their customers, or to pay generators on time. Distribution sector reform is of utmost importance.

Fortunately, within the country, we have a large reservoir of useful policy experience. This report, which extracts lessons from these experiences, is extremely timely, and I am certain it will be useful to all policy makers engaged in the essential task of reforming the distribution sector.

Dr V K Saraswat

Member, NITI Aayog 

Iहा?

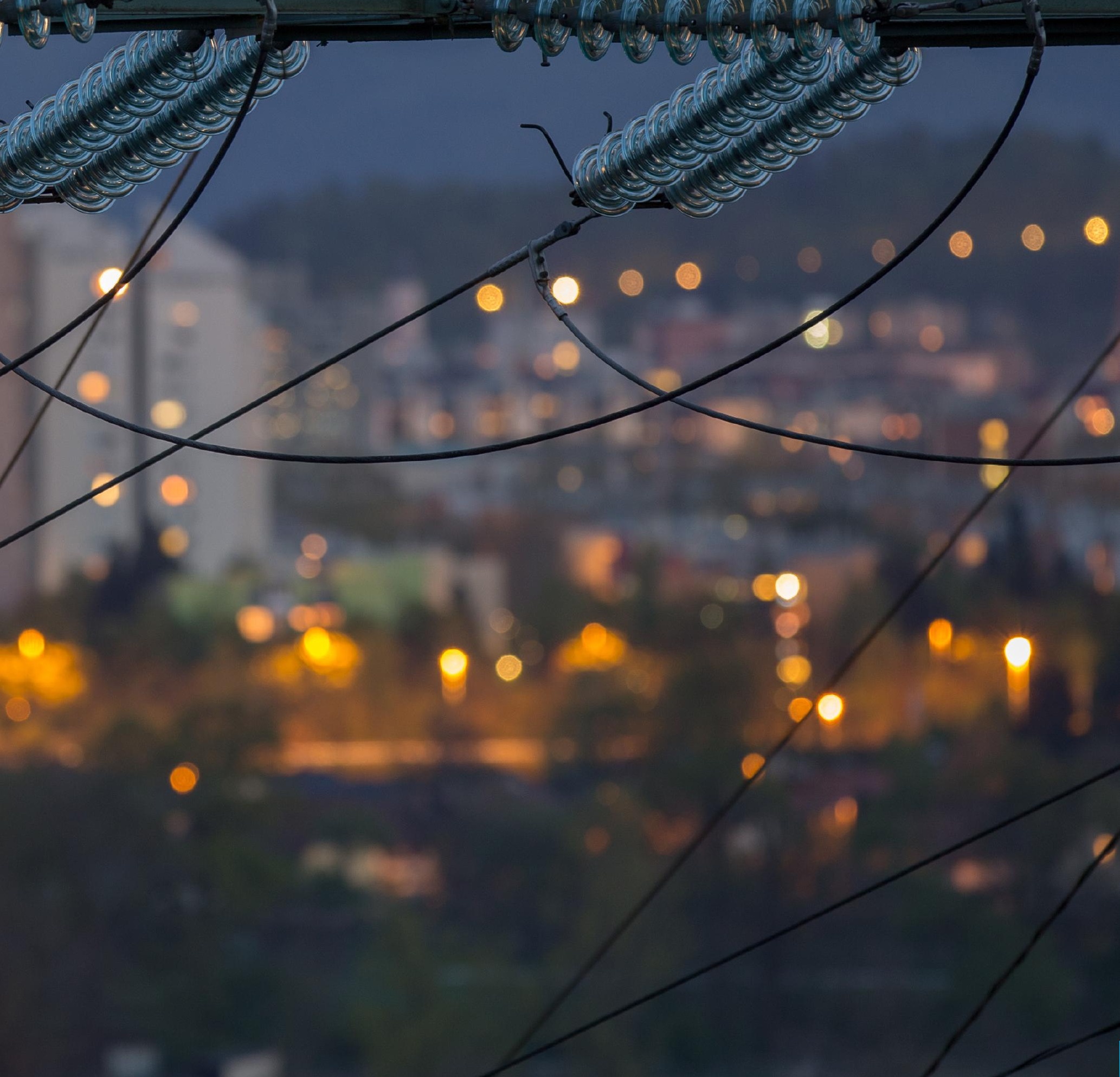




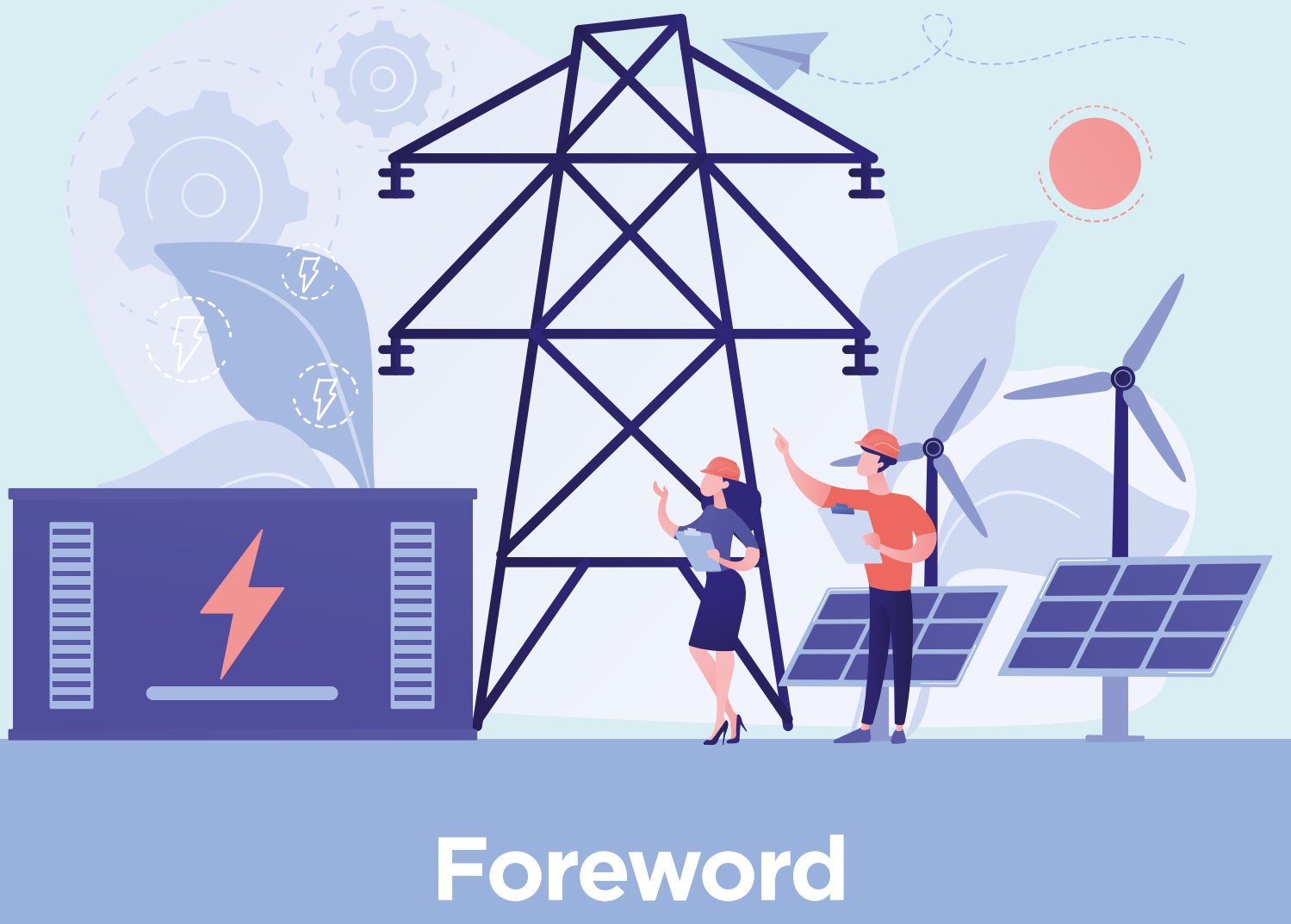

The Indian power sector is on course for a decade of transition and transformation. India's progress on renewable energy generation over the past decade has been inspiring and Hon'ble Prime Minister Narendra Modi's continued commitment to achieve 450GW has underpinned this momentum. Recent efforts, including the draft National Electricity Policy 2021, the announcement of the Ancillary Services Market regulation and the Market-Based Economic Dispatch (MBED), signal promising progress. Once implemented, these developments will allow new assets such as batteries and demand response to participate in providing grid services and will transition power procurement to a marketbased mechanism that enables least-cost, clean generation.

These developments signal the resolve of the Government of India to transform the power sector by incorporating new business models and clean energy portfolios that can modernise the grid and improve the sector's financial and operational performance.

India's distribution companies (discoms) are a vital stakeholder group in this transition that may hold the key to the future of the sector. The $₹ 3,00,000$ crore power discom reform scheme that the Indian cabinet has recently approved attests to the importance of discom transformation efforts. India has an opportunity to seize the moment and leverage the cost savings, system efficiency, and environmental benefits that clean energy portfolios bring to bear. The benefits of discom turnaround driven by clean energy portfolios will stand to pay long-term dividend in the sector's march towards a clean energy transition.

Jules Kortenhorst CEO, RMI 



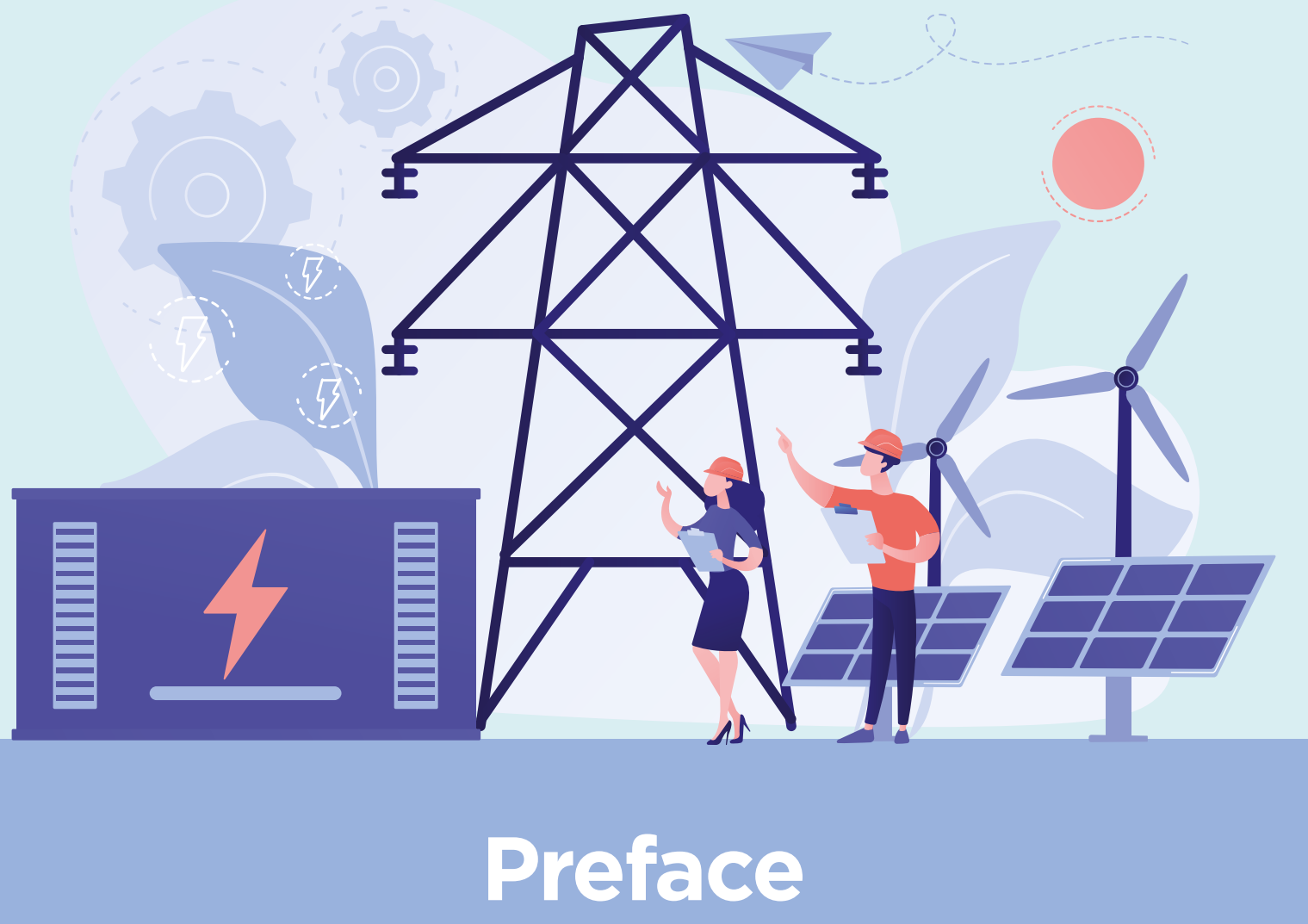

India has set ambitious targets for the power sector. We are aiming for $24 \mathrm{X} 7$ power for all, with $450 \mathrm{GW}$ of renewable capacity by 2030. Many of the government's major initiatives, such as Make In India or Aatmanirbhar Bharat, require access to reasonably priced, high quality power to take off.

However, the distribution sector has been the Achilles' heel of the power sector, consistently making large losses (estimated at Rs $90,000 \mathrm{cr}$ for FY 21), reflecting weaknesses in operations, infrastructure, and regulation. We will not be able to achieve a high-growth, low-carbon economy unless the distribution sector achieves profitability. The solution to this problem will include smart meters and smart grids, but the most important solutions might lie in institutional smartness - whether in power procurement, in ensuring highquality regulation, or in encouraging private participation in distribution.

Different states in India have followed different reform trajectories, and today, policymakers can draw upon a wealth of accumulated experience. This report aims to document the best practices and lessons from across India, and where required, across the world. I congratulate the authors at the Energy Vertical of the NITI Aayog, and at Rocky Mountain Institute. I am certain the report will be an extremely useful resource for policy-makers.

Amitabh Kant CEO, NITI Aayog 


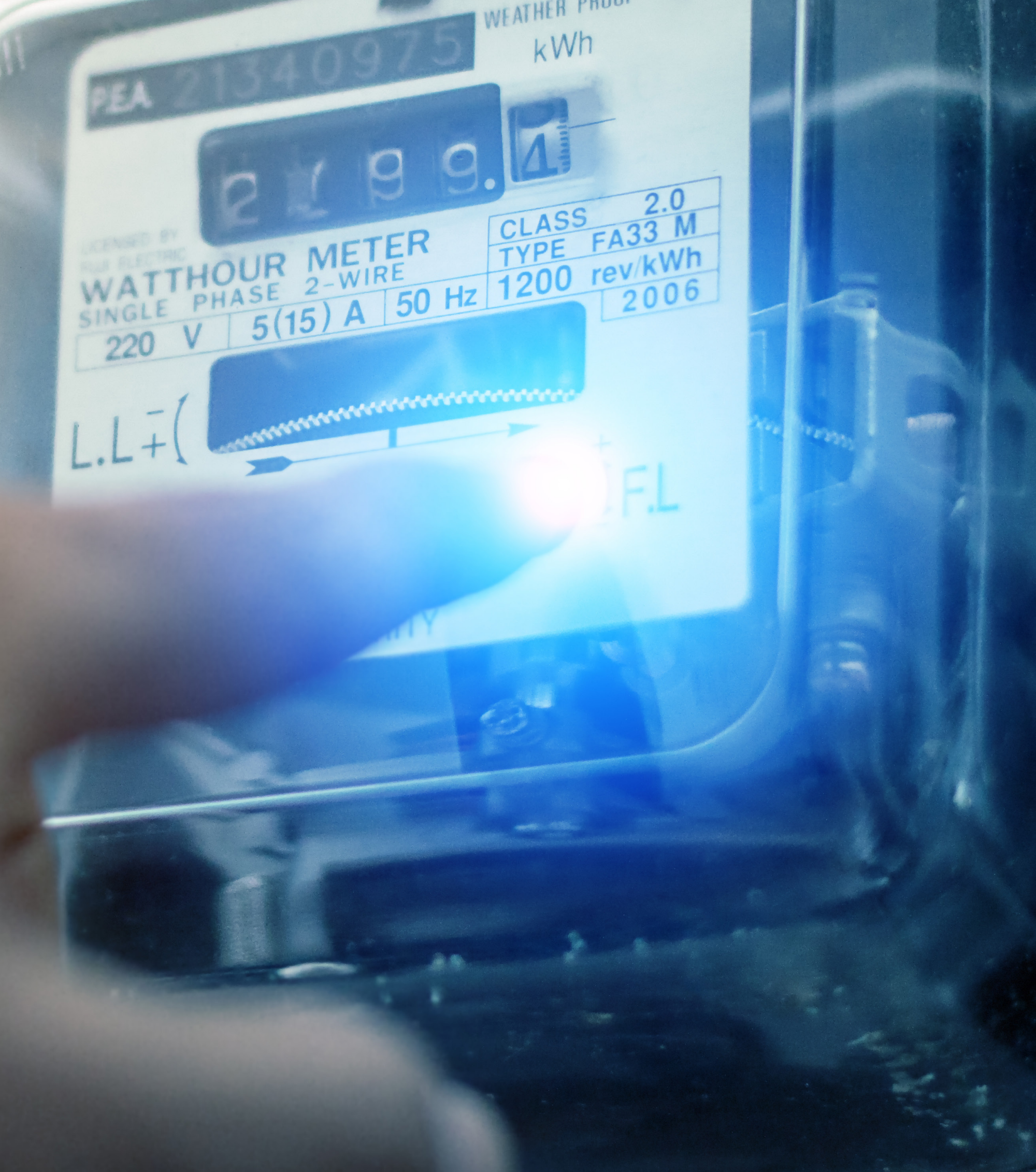




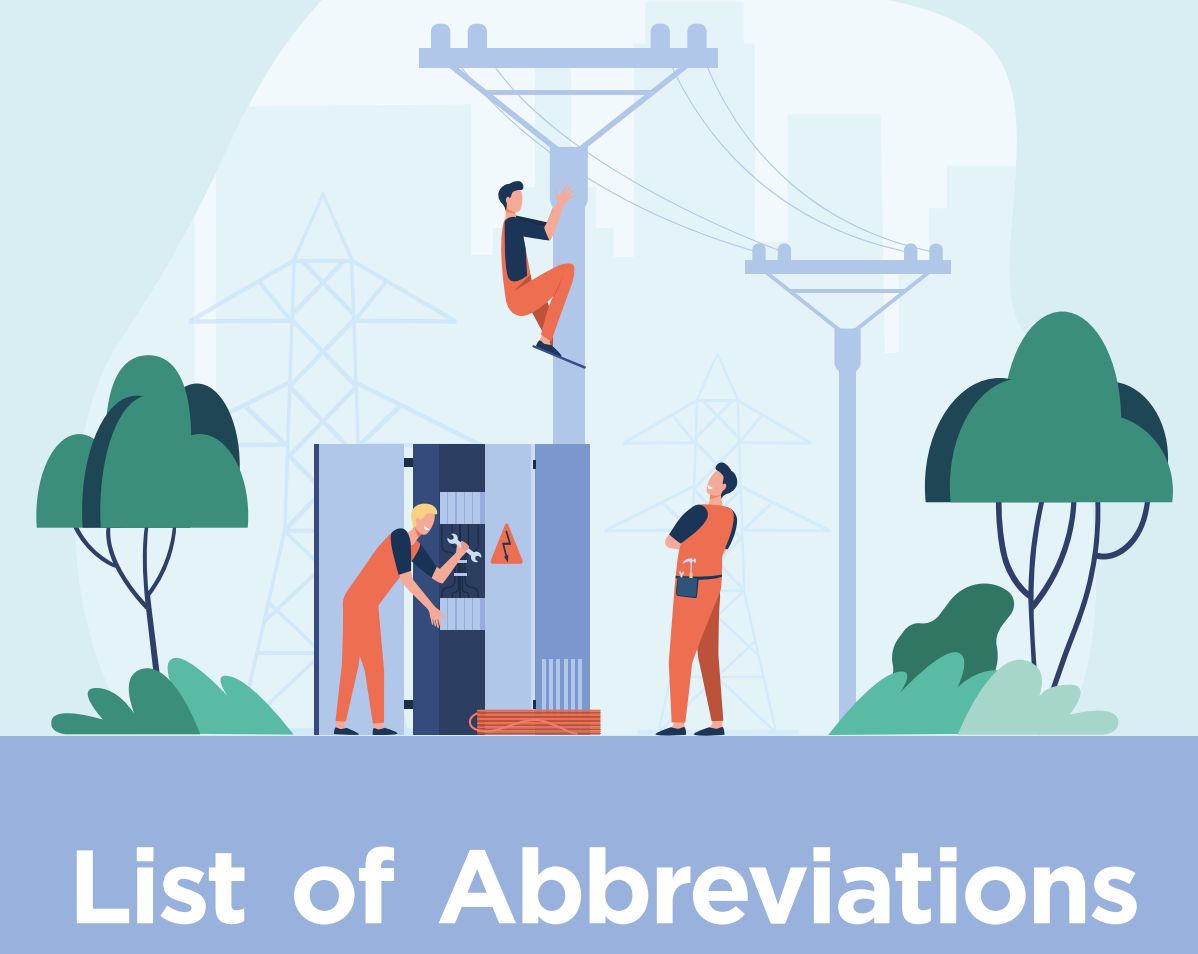

Abbreviation

Definition

\begin{tabular}{cl} 
ACS & Average Cost of Service \\
\hline AMS & Advanced Metering System \\
\hline APPC & Average Power Purchase Cost \\
\hline ARR & Average Revenue Realisation \\
\hline AT\&C & Aggregate Technical and Commercial \\
\hline BTM & Behind-the-Meter \\
\hline C\&I & Commercial and Industrial \\
\hline CAGR & Compound Annual Growth Rate \\
\hline CEA & Central Electricity Authority \\
\hline CERC & Central Electricity Regulatory Commission \\
\hline CRM & Customer Relationship Management \\
\hline DBT & Direct Benefit Transfer \\
\hline DDUGY & Deen Dayal Upadhyaya Gram Jyoti Yojana \\
\hline DF & Distribution Franchisee \\
\hline DL & Distribution License \\
\hline DRE & Distributed Renewable Energy \\
\hline
\end{tabular}




\begin{tabular}{|c|c|}
\hline DSM & Demand-side Management \\
\hline DT & Distribution Transformer \\
\hline DVB & Delhi Vidyut Board \\
\hline EA & Electricity Act \\
\hline ERC & Energy Regulatory Commission \\
\hline FOR & Forum of Regulators \\
\hline GTAM & Green Term Ahead Market \\
\hline IEX & India Energy Exchange \\
\hline IPDS & Integrated Power Development Scheme \\
\hline IPP & Independent Power Producer \\
\hline MBED & Market-based Economic Dispatch \\
\hline NTP & National Tariff Policy \\
\hline OA & Open Access \\
\hline PPA & Power Purchase Agreement \\
\hline PXIL & Power Exchange India Limited \\
\hline RE & Renewable Energy \\
\hline REC & Renewable Energy Credit \\
\hline REMC & Renewable Energy Management Centre \\
\hline RLDC & Regional Load Despatch Centres \\
\hline RTM & Real-time Market \\
\hline RTS & Rooftop Solar \\
\hline SARAL & State Rooftop Attractiveness Index \\
\hline SERCS & State Electricity Regulatory Commissions \\
\hline SLDC & State Load Despatch Centre \\
\hline SLT & Strategic Leadership Team \\
\hline ToD & Time of Day \\
\hline TPDDL & Tata Power Delhi Distribution Limited \\
\hline UDAY & Ujwal DISCOM Assurance Yojana \\
\hline UT & Union Territories \\
\hline
\end{tabular}




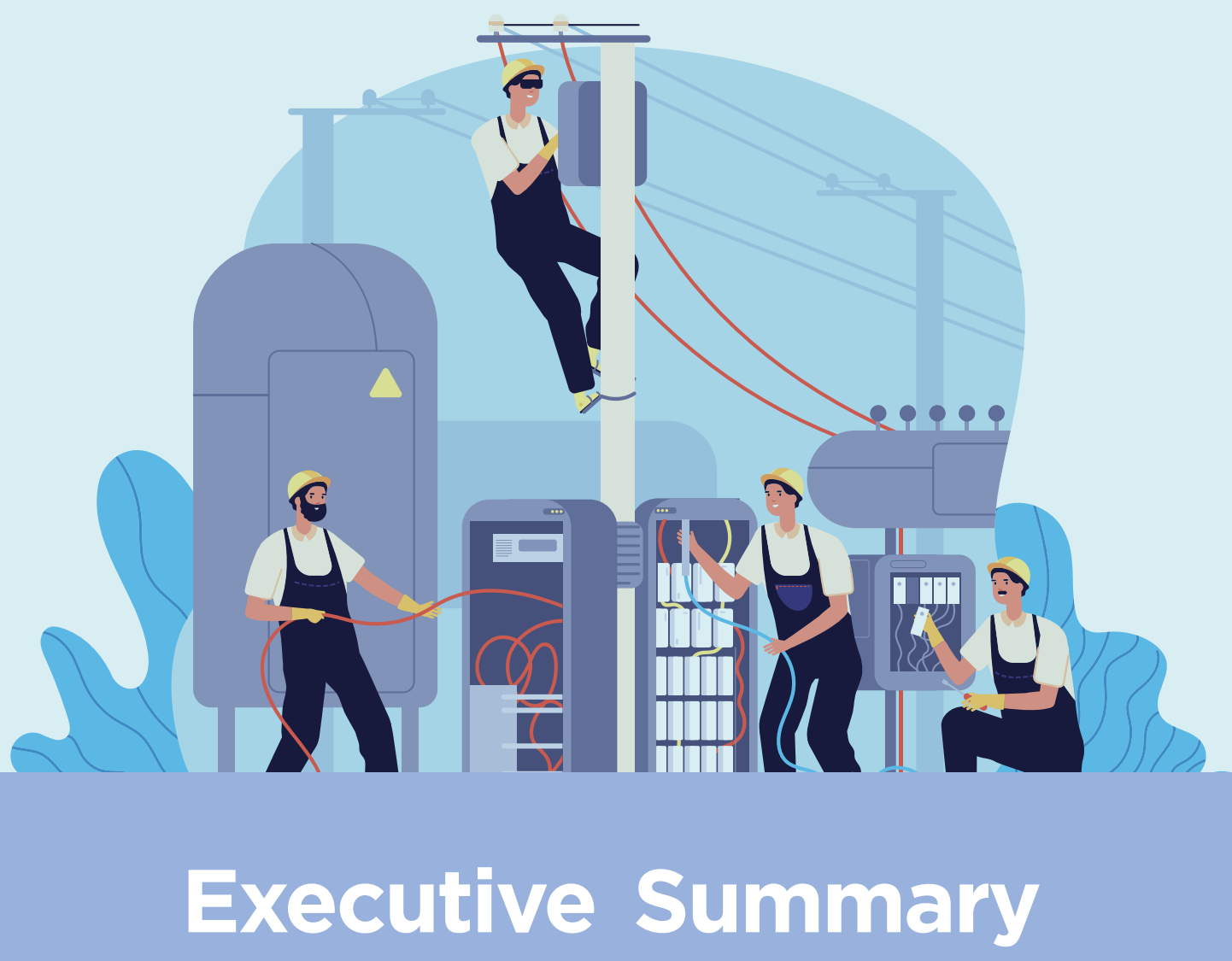

\section{The Challenge}

India has one of the largest and most complex power sectors in the world. Over the past few decades, the country has witnessed a remarkable evolution. Today, almost every citizen has access to grid electricity, power deficiency has decreased sharply, and the installed renewable energy capacity has reached a fourth of the total capacity.

However, the sector still faces significant challenges. Most power distribution companies (or discoms) incur losses every year-the total loss is estimated to be ₹ 90,000 crore in FY 2021.

Due to these accumulated losses, discoms are unable to pay for generators on timeas of March 2021 an amount of ₹ 67,917 crore was overdue. ${ }^{2}$ They are also unable to make the investments necessary for ensuring continuous high quality power, or build the infrastructure required to facilitate the transition from fossil fuel to renewable (but intermittent) energy sources, such as solar or wind.

Part of the reason for these losses is the tension between two different outlooks: (a) is electricity an essential public service whose provision at low rates is necessary for citizen welfare, or (b) is it a commodity to be bought and sold on the market like any other?

Many efforts have been made to turn around the distribution sector. Since the ' $90 \mathrm{~s}$, most state electricity boards have been unbundled into separate entities for generation, transmission, and distribution. The Electricity Act (EA), 2003, brought about major changes in the power sector, including delicensing of generation, open access in distribution, and 
independent regulators at the state and central levels. A series of schemes was launched, by central and state governments, to upgrade the distribution infrastructure and help the discoms improve their finances. Some of these initiatives include Ujjwal DISCOM Assurance Yojana (UDAY), Deen Dayal Upadhyaya Gram Jyoti Yojana (DDUGJY), and Integrated Power Development Scheme (IPDS). A revamped reform scheme, with an allocation of ₹ 3.05 lakh crore, was also announced in this year's Budget. However, the schemes implemented so far have not been able to ensure a sustainable turnaround of the discoms. A turnaround, in terms of both finances and operations, remains urgent.

The answer lies in significant policy, organisational, managerial, and technological changes. Different states have travelled along different pathways of reforms, giving us a rich set of policy experiments to learn from. Some of these learnings have been described below.

\section{Discom Restructuring}

The distribution sector has been largely vertically unbundled-the three different functions of generation, transmission, and distribution have now been separated. While there might be de jure unbundling, the degree of de facto unbundling might vary. In states such as Gujarat, the unbundling was an important step towards improving the performance of discoms.

Most discoms are state-owned, and only about 10 percent of India's population is served by private distribution licensees. For a state-owned utility to succeed, there should be a clear separation between utility and state. Good corporate governance practices, including the use of independent directors, can help ensure such separation.

Higher private participation in distribution holds out the possibility of greater efficiency. Franchisee models have been successfully implemented in Odisha and Bhiwandi in Maharashtra, where there have been rapid improvements in metering, billing, and collection.

In Delhi, after power distribution was taken over by three private licensees, the Aggregate Technical and Commercial (AT\&C) losses have come down from about 55 percent in 2002 to about 9 percent in 2019.

The recent Budget announcement delicenses distribution and proposes to allow distribution companies non-discriminatory access to the distribution system. Discoms have a monopoly in their area of functioning. Delicensing distribution can introduce competition and enable retail choice for customers. This reform can be challenging to achieve and should be accompanied with careful market design.

A public-private partnership (PPP) model can be especially useful in loss-making areas, where commercial operation might not be feasible without support in the form of viability gap funding (VGF) by the government.

\section{Regulatory Reforms}

The state governments should promote autonomy, competence, and transparency of the State Electricity Regulatory Commission (SERC). Tariffs should be regularly revised 
to ensure that they fairly reflect the actual fixed and variable costs. No new regulatory assets should be created. The existing regulatory assets should be cleared according to a defined schedule over the next three-to-five years through appropriate tariff changes.

One way to insulate regulatory functions from political pressures is to create regional electricity regulatory commissions with the participation of the central government.

For consumers, who receive subsidised electricity, direct benefit transfer (DBT) can help improve efficiency and reduce leakages. It has recently been implemented in parts of Madhya Pradesh. ${ }^{3}$ The respective state government should prescribe the details of the DBT scheme. It could be structured such that consumers do not stand to lose their current benefits, but are paid more for efficient use of electricity, similar to the 'Paani Bachao Paise Kamao' scheme in Punjab.

\section{Operational Reforms}

The overall AT\&C loss figure in India is as high as 24.54 percent.i Many discoms need to improve their billing efficiency through better metering. They should fully utilise the revamped central government reform scheme to achieve 100 percent metering using prepaid or smart meters while being cognisant of cybersecurity threats. Thefts can be reduced through concerted action by the discoms and states. Prepaid metering can help reduce thefts and increase collection, as in the case of Manipur. Another frequent reason for low collection is default in payment by state government departments and municipal bodies.

In Gujarat, discoms were able to significantly reduce their technical losses through investment in improving their grid. Investment in distribution infrastructure is a major component of the revamped central government reform scheme announced in Budget '21, and state discoms should aggressively use this support to upgrade their distribution infrastructure.

Many states provide subsidised and sometimes free electricity for agriculture. This can lead to leakages and high losses for discoms. Some states, with large agricultural consumer bases such as Rajasthan, Andhra Pradesh, Gujarat, Karnataka, and Maharashtra, have reduced leakages by separating feeders for agricultural use from non-agricultural use. Discoms can significantly decrease their power procurement costs by encouraging the use of solar pumps for agriculture.

Discoms have locked themselves into long-term, expensive power purchase agreements (PPAs). As long as the markets continue to provide low-cost power, discoms should not sign new expensive long-term thermal PPAs. States such as Chhattisgarh, Gujarat, Maharashtra, and Uttar Pradesh have banned new thermal PPAs till 2022. Where feasible, discoms can exit such expensive and long-term PPAs. Discoms can also reduce the cost

Often, state electricity regulators may recognise certain costs incurred by discoms, but they may not increase tariffs to match these costs to shield consumers from tariff shocks. Regulatory assets are the costs that are deferred for recovery through future tariff changes.

ii From Uday Portal (uday.gov.in/atc_india.php) as on April 28, 2021. 
of power by procuring cheaper power from the exchanges whenever the price on the exchange is lower than the variable cost of the PPA.

Discoms should use time of day (TOD) tariffs to incentivise changes in demand patterns. Dynamic tariffs, enabled by advanced metering and a smart grid, can reduce the discoms' power purchase costs and help manage peak loads.

\section{Renewable Energy Integration Reforms}

Discoms need to prepare to accommodate an increasing amount of renewable energy (RE), from generators as well as prosumers.iii In order to increase the firmness ${ }^{i v}$ of RE power, reduce power procurement costs, and handle a variety of power sources, discoms may need to deploy large-scale energy storage. Storage can be provided by battery systems or pumped hydro-storage systems. Discoms need to develop better RE forecasting capabilities in order to reduce their deviation costs and reduce the need for real-time balancing.

States and discoms are mandated to meet the targets of renewable purchase obligations (RPOs) every year. However, the must-run status of RE means that some states end up purchasing more than what they need while falling short of their obligations. A stringent implementation of the RPO mandate would ensure a fairer distribution of the excess cost of absorbing RE.

Rooftop solar plants are attractive in many ways. They let consumers meet part of their load from renewable solar energy. Consumers can monetise their rooftops and sell the excess to discoms. However, it does pose some challenges to discoms. They may lose a high-paying consumer; it may not be economical for the discom to purchase power from the prosumer at the prescribed rate; ${ }^{v}$ and they may need to incur additional expenditure on infrastructure to accommodate the RE sold to them by the prosumer. Discoms should be fairly compensated for the additional expenses they may incur to integrate rooftop solar power generation. Further, tariffs for rooftop solar should be set so that all consumers and producers face fair price signals as relevant to their state. Off-grid solar plants should receive greater policy encouragement, as they can be cheaper and simpler than gridconnected solar plants.

Mini-grids (an electricity distribution network involving decentralised small-scale generation from locally available renewable energy sources) can provide more predictable power in remote and sparsely populated areas. They can also be used to provide greater resilience to critical infrastructure such as hospitals. A PPP model can be explored in such remote areas, with the government providing VGF in return for the concessionaire supplying power at a specified rate while meeting specified service quality targets. The

iii A consumer who also generates power, for instance, through a rooftop solar plant.

iv Firm power is power which is assured to be available.

$\checkmark$ In net metering, the consumer's electricity exports are adjusted against his imports and the consumer has to pay for the balance at the applicable retail tariff. In gross metering, the consumer pays the retail tariff for all the electricity he consumes, and he/she is paid at a specified rate (the feed-in tariff, which is generally lower than the retail tariff) for the energy he/she exports to the grid. 
mini-grid could also act as a distribution franchisee. The mini-grid could also be run by a panchayat, if the latter has developed sufficient capacity.

\section{Managerial Reforms}

Effective reforms are typically a result of stable leadership and vision sustained over time. Reform journeys in Andhra Pradesh, Gujarat, and New Delhi, were led by elected officials who retained their position in power for at least a decade.

Easily accessible call centres, convenient bill payment facilities, and accurate billing can help reduce customer dissatisfaction and increase revenue.

Performance incentives can help align discom employees to the interests of the organisation. Zones or circles in discoms could be treated as profit centres, with employees being given commensurate autonomy as well as responsibilities.

The operation and management of the power distribution business are complex activities. They require expertise in a variety of fields: engineering, finance, billing and collection, $\mathrm{HR}$, administration, etc. There is a need to augment training and capacity building in these fields.

\section{Way Forward}

The history of power sector reforms tells us that India is too large and diverse for a one-size-fits-all approach. Importing external expertise, structural frameworks, and new technology will be required, but these steps will not be sufficient to drive India's power sector transition. Similarly, implementing retail choice through separation of content and carriage may not necessarily result in the full set of theoretical benefits touted. A flexible and home-grown approach to reform, which is supported by states and the Centre, and allows for 'learning by doing', will be instrumental in determining the success of reforms. 


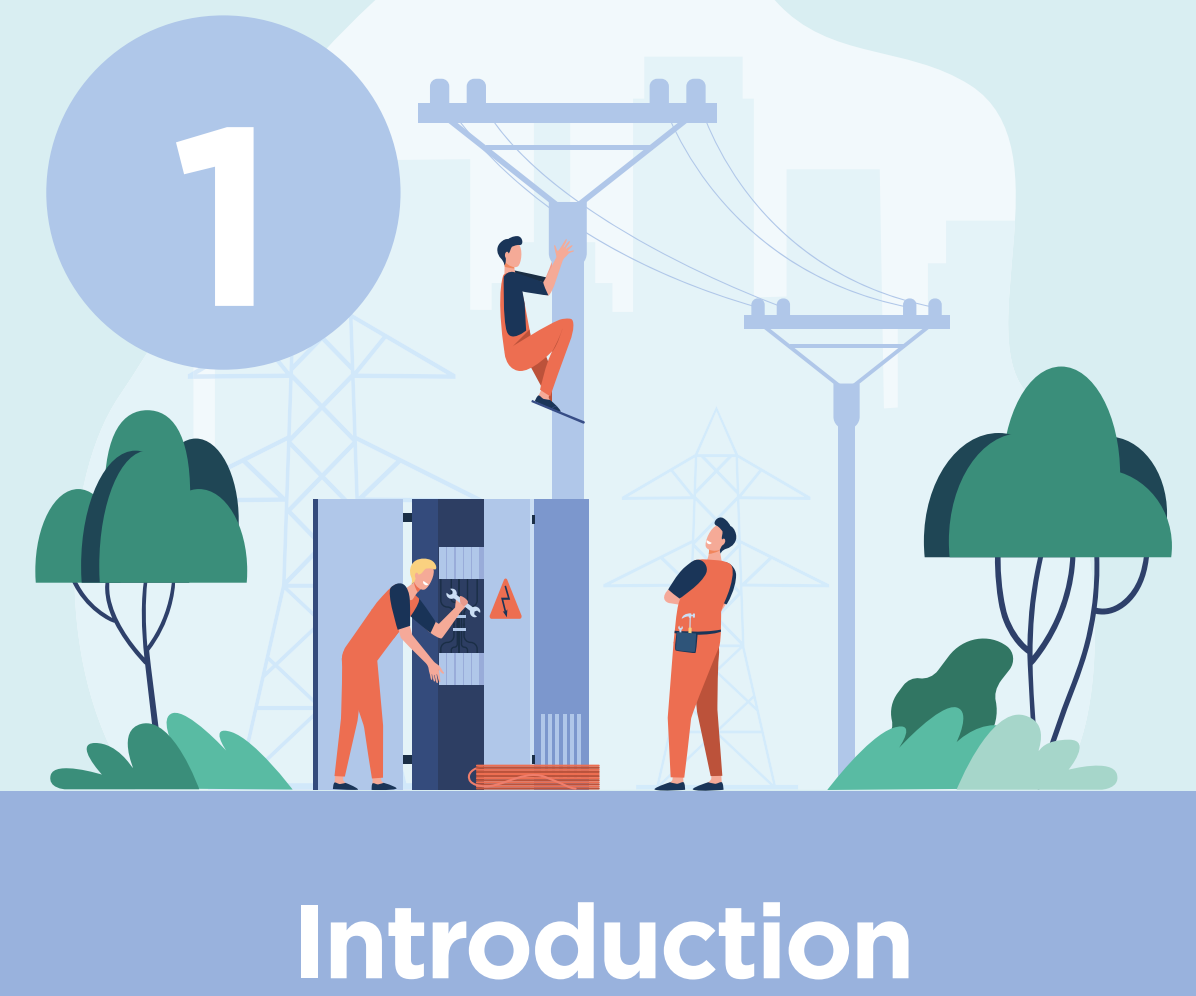

\subsection{BACKGROUND}

India has one of the largest and most complex power sectors in the world. Over the past few decades, the country has witnessed a remarkable evolution. Today, almost every citizen has access to grid electricity, power deficiency has decreased sharply, and the installed renewable energy capacity has reached a fourth of the total capacity.

Crucial to this evolution has been the EA 2003 that enabled a primarily state-owned sector riddled with mounting losses and debt to move towards a more open and competitive system. EA introduced many new policy features such as the introduction of competition through open access, multi-year tariff frameworks, distribution franchisees, de-licensing generation, establishment of renewable purchase obligations, and the creation of independent regulatory bodies.

However, the distribution sector is still mired in difficulties. Most discoms incur vast losses every year, and the situation is only getting worse with every passing day. Unable to pay generators on time, they have accumulated huge debts, and are not able to supply reliable and high-quality power to their customers. ${ }^{4} \mathrm{~A}$ financial and operational turnaround of the discoms is urgent.

Although discoms as a group are faring poorly, some individual ones are performing better than the others. Over the past few decades, different states and discoms have chosen different reform paths which have resulted in these varied outcomes. This report presents these learnings and best practices to help policymakers and practitioners bring about a financial and operational turnaround in the discoms' performance. 


\subsection{STATUS OF DISCOMS}

The challenges clouding the sector are manifold and involve the whole value chain. Exhibit 2 maps them out into three categories, operational and managerial, regulatory and political, and technological.

Cost optimisation continues to be difficult to achieve due to factors such as legacy PPAs and poor investment in distribution infrastructure.

At the revenue realisation end, underinvestment and line losses, as well as challenges related to billing, metering, and collection, stand out. These elements are aggregated under the larger structural challenges including governance and regulation. They emphasise the need to revamp the underlying sectoral and organisational functioning. The key challenges faced by discoms across the country are highlighted in the sections below.

\subsubsection{Operational Performance}

Fundamental to discoms' profitability are the activities of metering, billing, and collection. On the whole, continuous improvement in billing and collection efficiency (Exhibit 1) has gradually helped in reducing AT\&C losses across the country. The overall AT\&C loss has come down to 22 percent. However, when compared at the global level, losses are still high, and much is to be done. Even within the country, there is a sharp difference in performance between states.

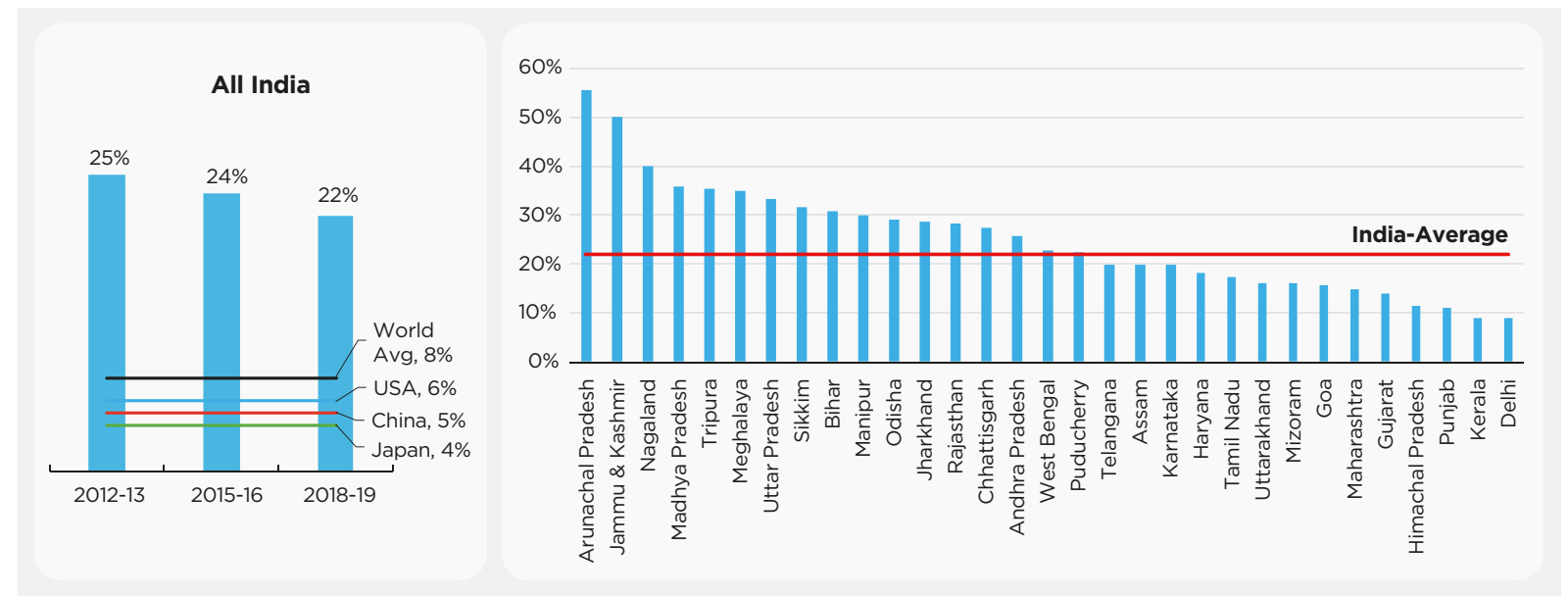

Exhibit 1: National and state-wise AT\&C losses for 2018-19

(Source: PFC. See Appendix 3 for details) 

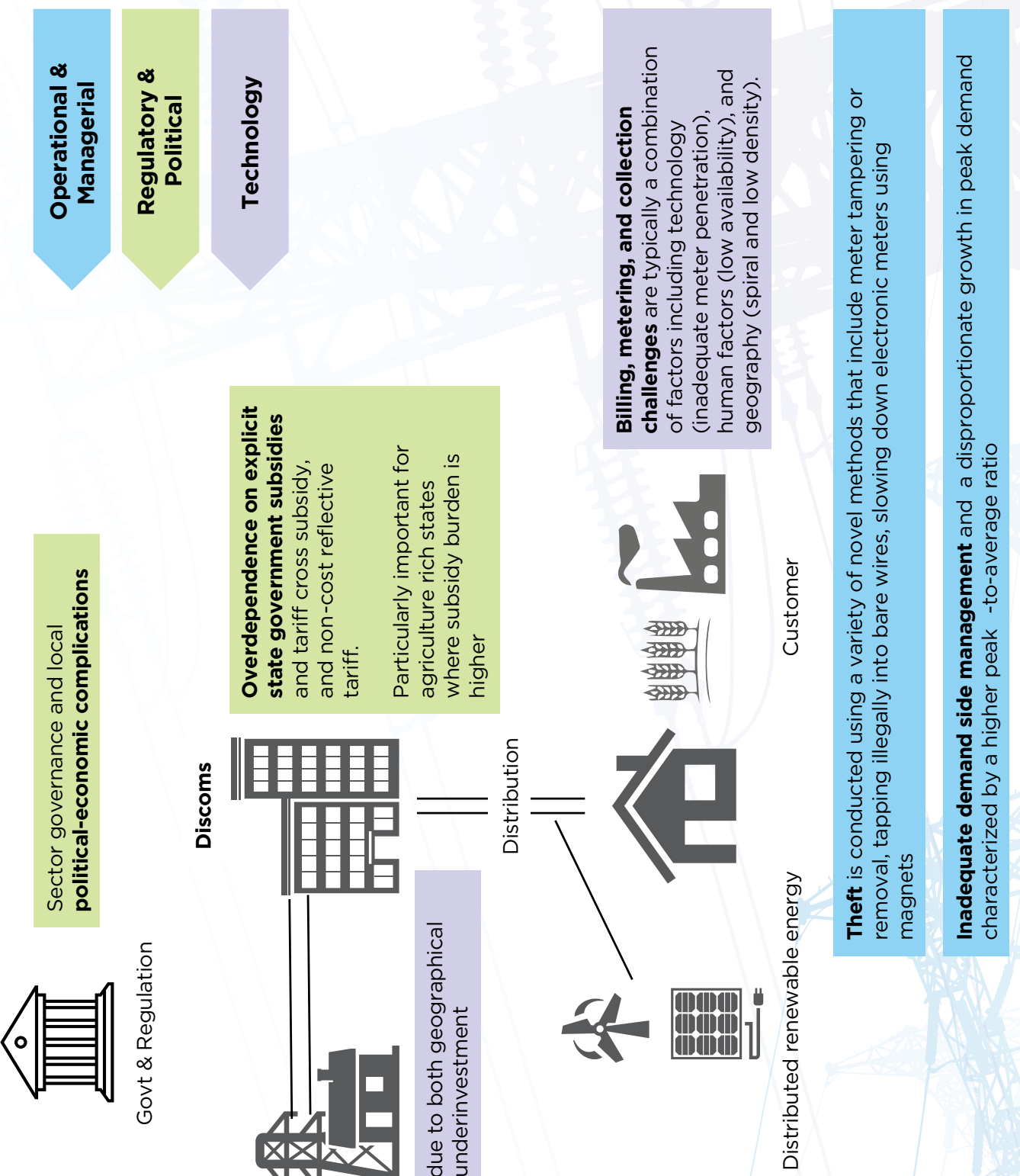

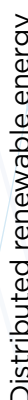
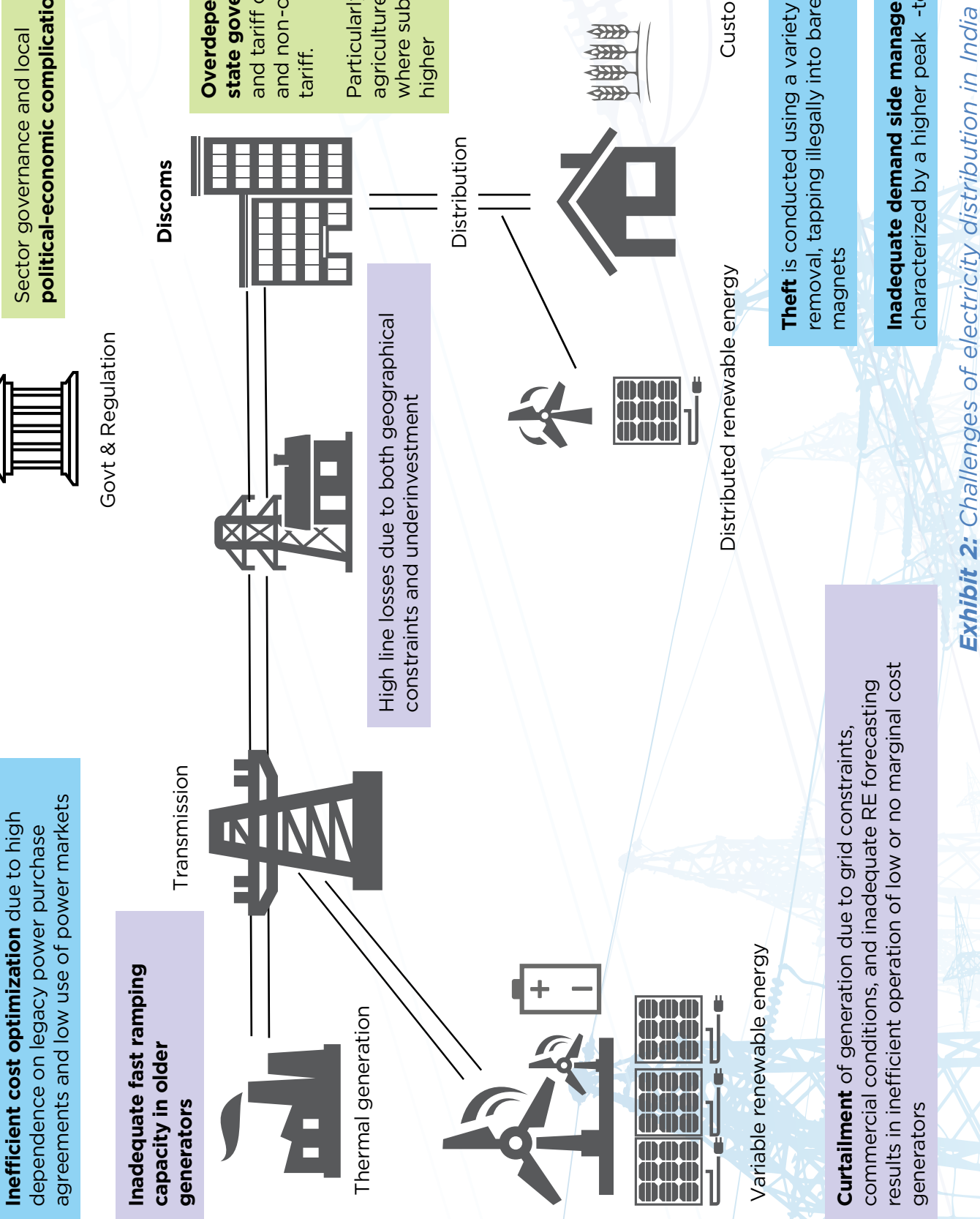
Table 1: Costs and revenue of distribution utilities, in ₹ crore (2018-19, source: PFC)

\begin{tabular}{|l|r|r|}
\hline \multicolumn{3}{|c|}{ Cost Structure } \\
\hline \multicolumn{1}{|c|}{ Head } & Rs Crore & \multicolumn{1}{c|}{$\%$} \\
\hline Cost of Power & 551535 & $77 \%$ \\
\hline Employee Cost & 56804 & $8 \%$ \\
\hline Interest Cost & 47632 & $7 \%$ \\
\hline Depreciation & 21887 & $3 \%$ \\
\hline Other Costs & 34752 & $5 \%$ \\
\hline Total & 712610 & $100 \%$ \\
\hline
\end{tabular}

\begin{tabular}{|l|r|r|}
\hline \multicolumn{3}{|c|}{ Revenue Structure } \\
\hline \multicolumn{1}{|c|}{ Head } & Rs Crore & \multicolumn{1}{c|}{$\%$} \\
\hline Revenue from Operations & 491985 & $74 \%$ \\
\hline Tariff subsidy Booked & 110391 & $17 \%$ \\
\hline Regulatory Income & 3872 & $1 \%$ \\
\hline Revenue Grant UDAY & 20570 & $3 \%$ \\
\hline Others & 36275 & $5 \%$ \\
\hline Total & 663093 & $100 \%$ \\
\hline
\end{tabular}

In 2018-19, distribution utilities incurred a total expenditure of $₹ 7,12,610$ crore against a total revenue of ₹ $6,63,093$ crore (this is on a subsidy-booked basis with UDAY grants included, see Table 1). About 77 percent of the cost was the cost of power alone. The other major heads of costs included employee costs ( 8 percent) and interest costs ( 7 percent). Of the revenue, about 74 percent was from the sale of electricity, and 17 percent from the booked tariff subsidy. ${ }^{5}$

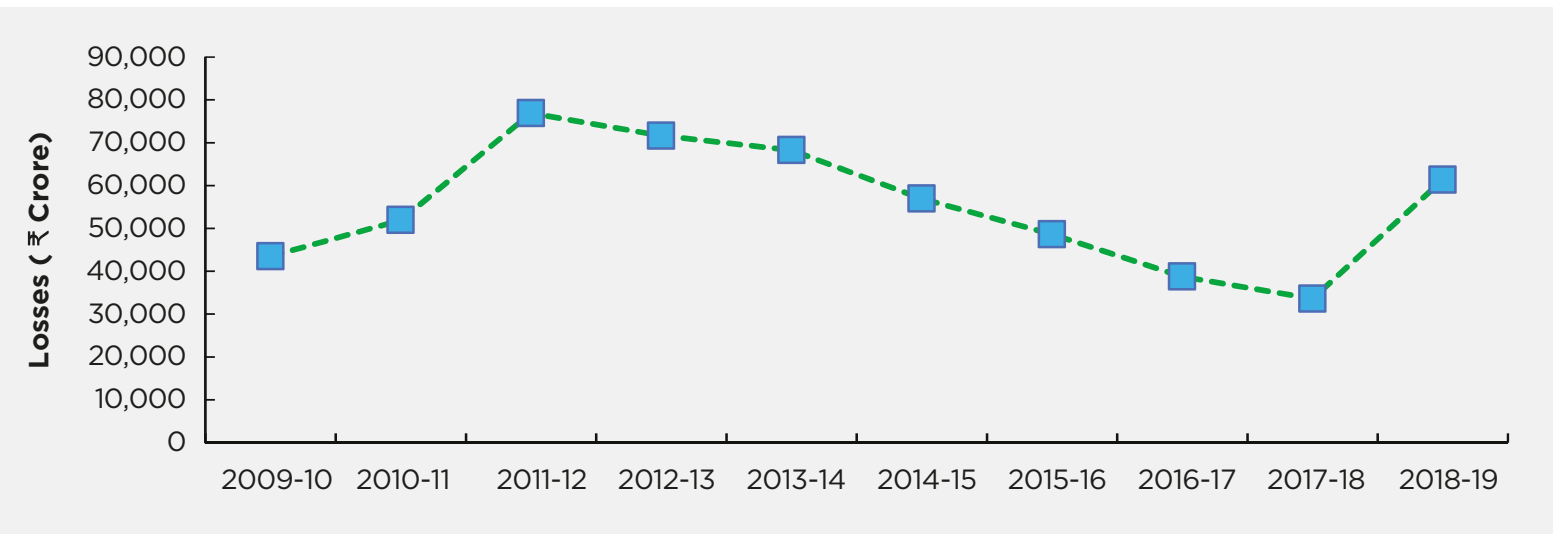

Exhibit 3: Total discom losses (after tax, with tariff subsidy received) over time

(Source: PFC, see Appendix 1 for details)

In Exhibit 3, it is observed that the losses of the discoms declined from a peak of ₹ 76,878 crore in 2011-12 to ₹ 33,596 crore in 2017-18. However, losses increased sharply in 2018-19. The Covid-19 pandemic and the subsequent lockdown further damaged the discoms' finances. Due to its adverse impact, the electricity demand of commercial and industrial (C\&I) customers also suffered. It is projected that the total loss could rise to $₹ 75,000$ crore in FY $2022 .{ }^{6}$

The gap between the average cost of supply (ACS) and the average revenue realised (ARR) increased from ₹ 0.54 / kWh in 2012-13 to almost ₹0.72 / kWh in 2018-19 (see Exhibit 4). Different states performed differently - for example, those with private discoms such as Delhi and those with large hydro resources, with comparative cost advantage, such as Himachal Pradesh and Kerala, fared comparatively better. 


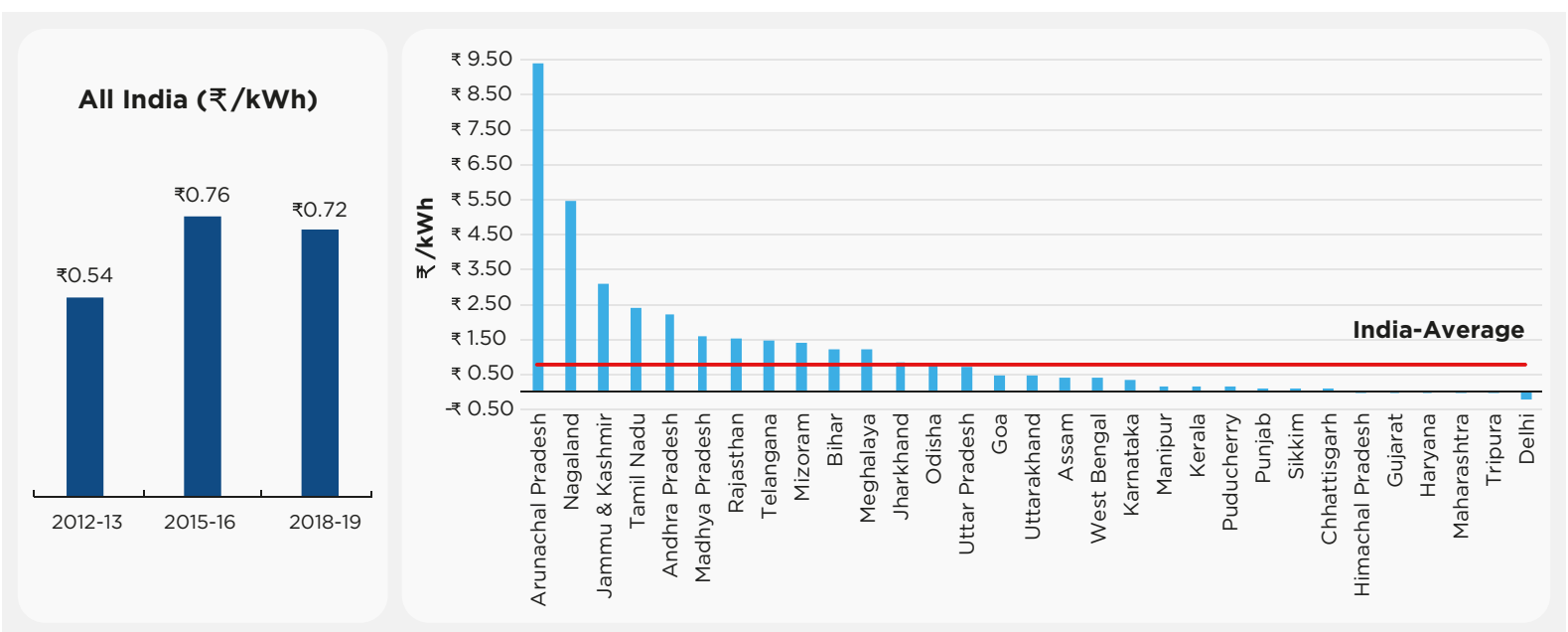

Exhibit 4: Discom profitability normalised as the ACS-ARR gap for 2018-19

(Source: PFC)

\subsubsection{Subsidy Dependence}

Even while analysing the sector's subsidy dependence, regional variability emerges clearly. For example, discoms in the north-eastern states and agrarian states are especially dependent on government subsidies (see Exhibit 5).

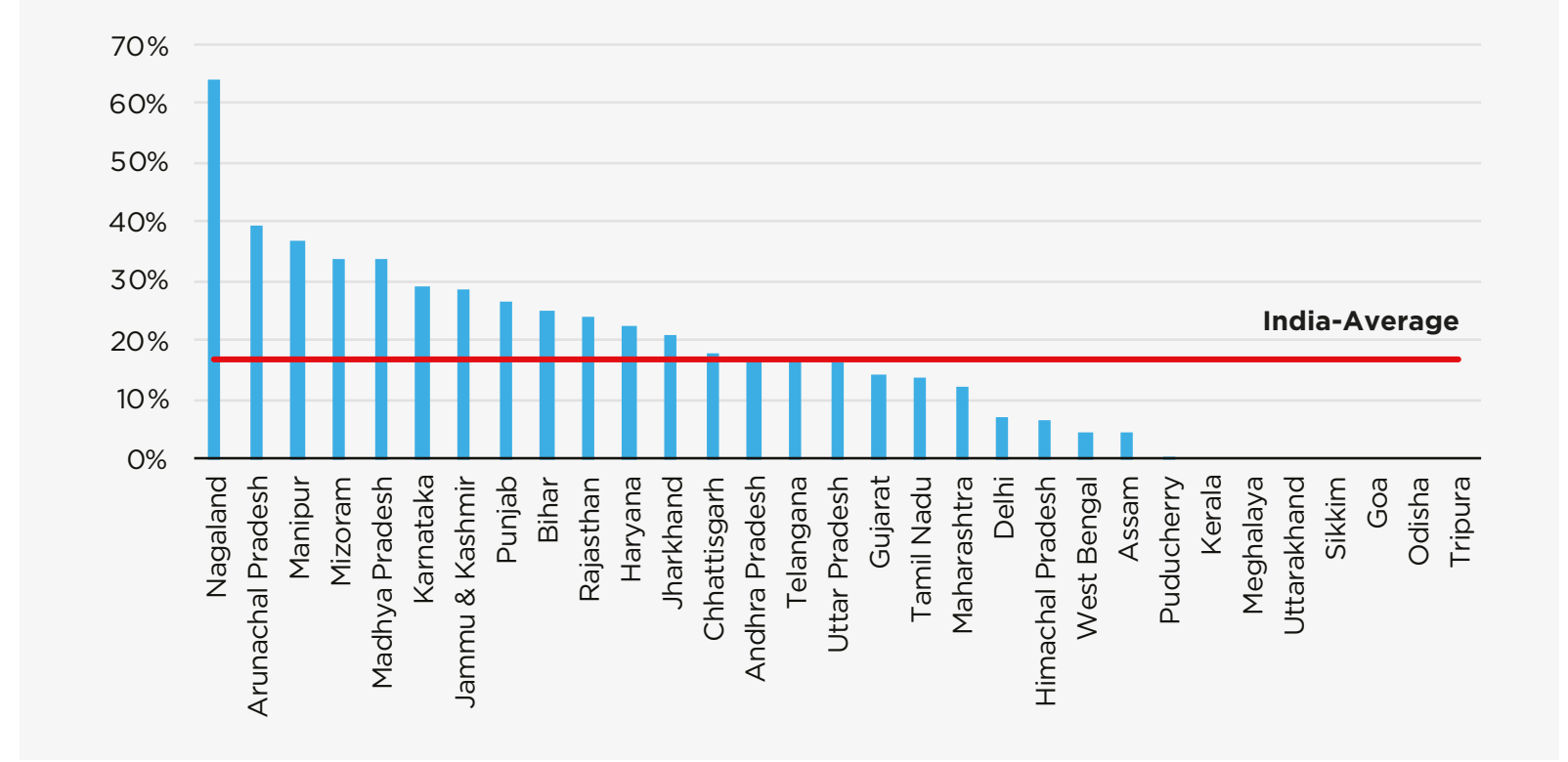

Exhibit 5: Tariff subsidy as a share of discom total revenue for 2018-19 (Source: PFC)

Apart from straining a state's finances, continued reliance on subsidies disincentivises discoms from making serious structural improvements. Delays in receiving subsidy reimbursements from the government add to the liquidity stresses of discoms. 


\subsubsection{Outstanding Dues}

These systemic shortcomings ultimately result in a high level of debt and payments owed to generation companies (gencos). The overdue amount to gencos stood at ₹ 67,917 crore in March 2021.7 See exhibit 6 for a state-wise breakup.

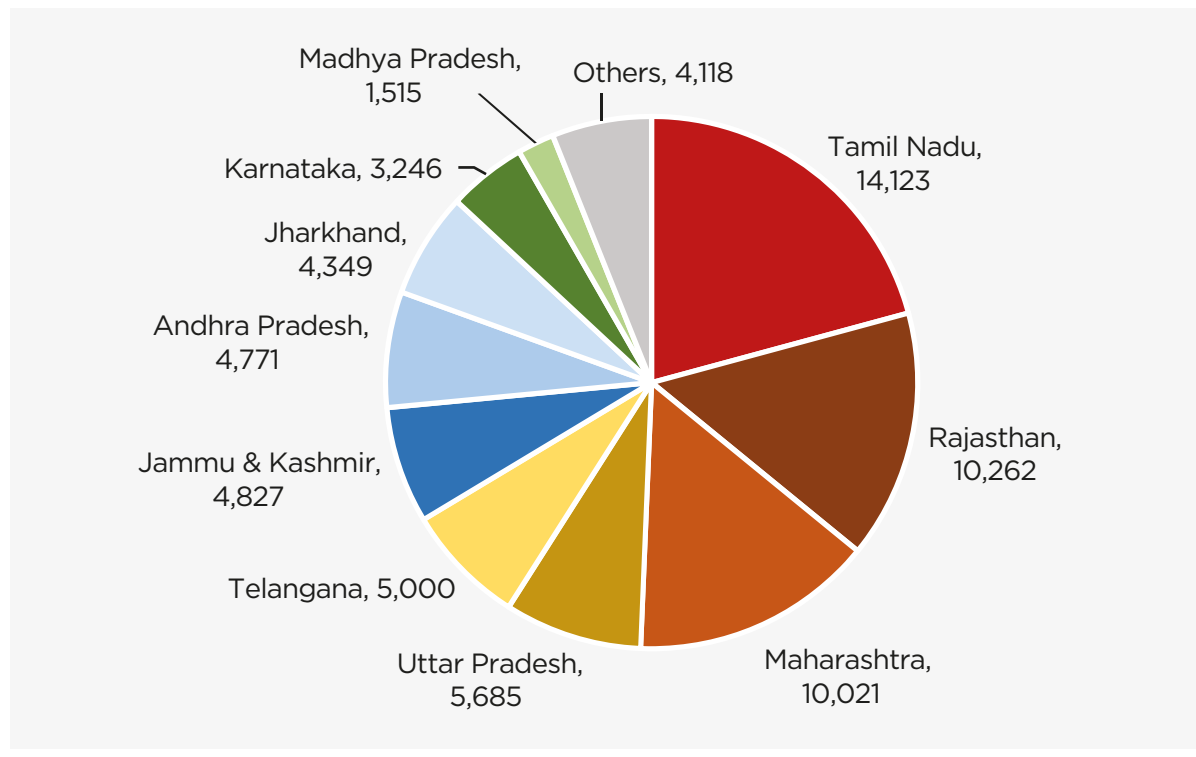

Exhibit 6: State-wise Overdue to Gencos (In ₹ cr)

(Source: PRAAPTI)

\subsubsection{Role of Taxes}

Multiple taxes and duties are levied on coal which is responsible for more than half of the electricity generated in the country. The taxes include royalty on basic price (14 percent), Goods and Services Tax (GST 5 percent) and GST Compensation cess (₹400 per tonne), among others. The transportation of coal is also expensive as railway freight charges are used to cross-subsidise passenger transport. Given that discoms have little control over bulk supply tariff and are engaged in long-term PPAs with generating companies, these taxes get transferred via tariffs to end consumers. ${ }^{8}$

The states charge electricity duty based on consumption. This may differ from state to state and can go up to 20 percent in some cases. It may be noted that while coal is under GST, the end product, electricity, is not. This prevents utilities from accessing the input tax credit mechanism, leading to a cascading effect where the taxes that are levied on utilities are added to the cost of power. This results in higher tariffs for end users. Currently, consumers in the states of Maharashtra, West Bengal, and Madhya Pradesh pay the highest electricity tariffs in the country. ${ }^{9}$ It is estimated that under GST, per unit cost of power can reduce by 17 paisa across the power value chain on account of availability of input tax credit. ${ }^{10}$

The utilities, including discoms, are also required to pay corporate tax, which has a direct implication on power tariffs for consumers. Last year, the corporate tax rate was lowered to 15 percent. New companies that will begin generating electricity from March 2023 onwards can benefit from this lower tax rate." 


\subsubsection{Impact of Covid-19}

The ongoing Covid-19 pandemic has further distressed discoms. The sharp downturn in demand from high-paying C\&I customers during the lockdown negatively impacted the discoms' finances. The decline in sales to C\&I consumers is likely to increase the subsidy dependence of discoms to one trillion rupees in 2020-21 due to the rising revenue gap. ${ }^{12}$ The pandemic accelerated the discoms' outstanding dues to ₹ 1.39 lakh crore as of October 2020, breaching the pre-UDAY peak of ₹ 1.3 lakh crore in 2015. Dues to generators increased 34.4 percent year-on-year to more than one trillion rupees as of October $2020 .^{13}$

A discom sector liquidity infusion scheme of ₹90,000 crore was announced in May 2020 by the central government. Later, the limit was enhanced further. This liquidity infusion has helped the discoms with immediate debt repayments and with payments to generation companies. ${ }^{14}$

With these loans, the gross debt level for state-owned discoms may reach as high as ₹6 lakh crore in FY 2022. Such high levels of debt may not be sustainable and a significant improvement in operational efficiencies as well as a reduction in the gap between the tariff and cost of supply are imperative to improve the discoms' financial situation. ${ }^{15}$

\subsection{DISTRIBUTION SECTOR REFORMS}

\subsubsection{The Journey So Far}

During the '90s, many developing countries across the world started reforming their power sectors. In India, states such as Odisha, Andhra Pradesh, and Rajasthan took the lead in passing legislation to reform the power sector. This comprised a set of four structural reforms: the creation of an independent regulator; unbundling of vertically integrated utilities; increasing private sector participation; and encouraging competition. ${ }^{16}$

Under the Indian Constitution, electricity is mentioned in the Concurrent List. Both Parliament and state legislatures can frame laws on electricity. In case of a conflict between the two, the law promulgated by the state legislature will be void to the extent it contravenes Parliamentary legislation. The responsibility for the distribution of power to rural and urban consumers rests with states. ${ }^{17}$

At the national level, EA 2003,18 was instrumental in India's power sector turning the corner. It enabled the sector to be more open and competitive through: the unbundling of the SEBs; introduction of competition through open access; multi-year tariff frameworks; distribution franchisees; delicensing thermal generation while establishing RPOs; setting up regulatory bodies, CERCs and SERCs, and an appellate tribunal for dispute resolution; and calling for universal electricity access.

India's power sector has been slowly marching towards competition and liberalisation over the past two decades. The journey of the electricity sector has seen a series of attempts to introduce competition through market reform and periodic support through major schemes and infrastructure improvement (Exhibit 7). At the macro level, the Centre's role has been crucial in providing policy direction, front-loaded infrastructure investments, and financial support. 


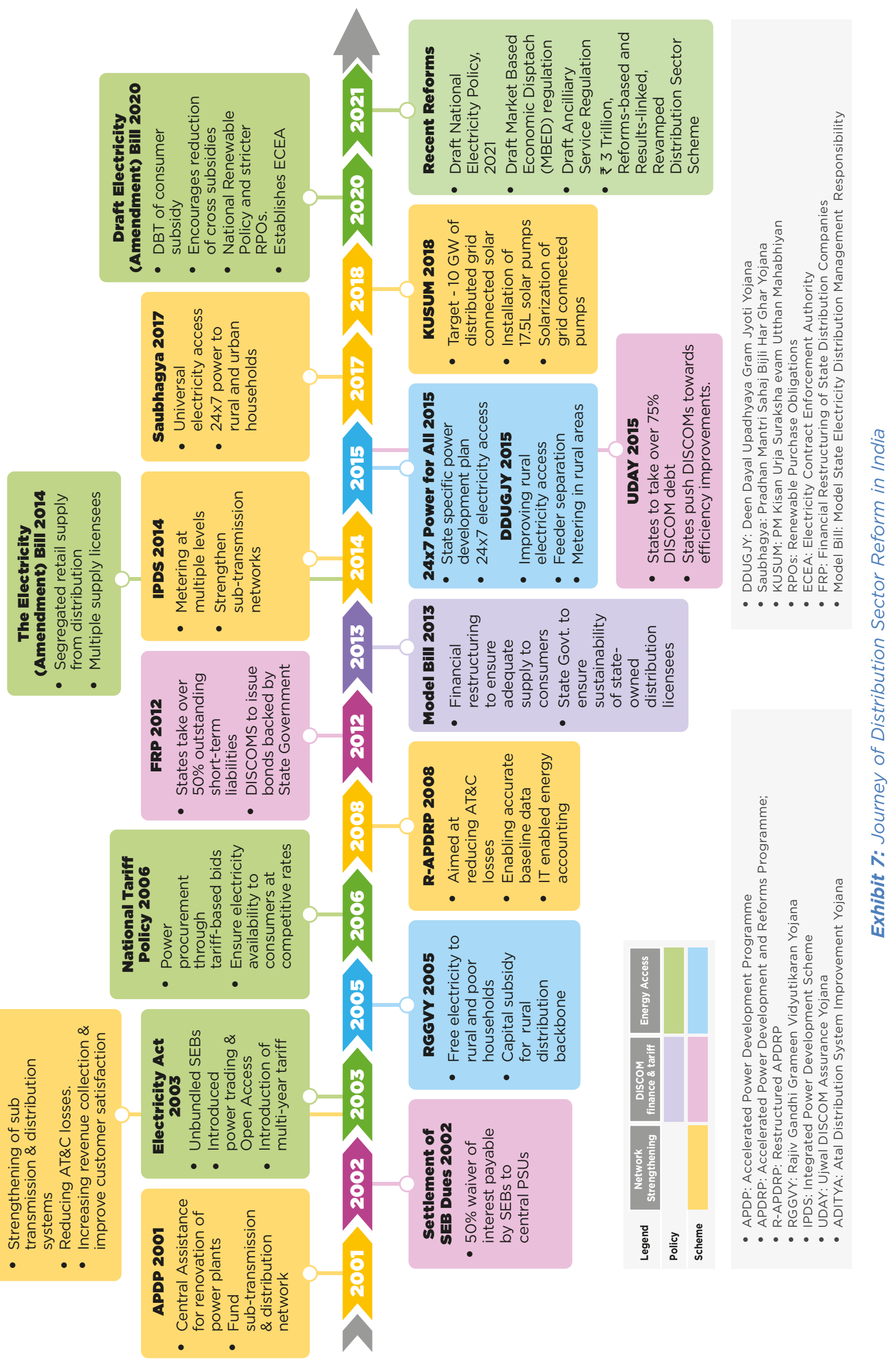


The Electricity Act also mandated the central government to formulate and review the National Electricity Policy and Tariff Policy in consultation with the state governments and the Central Electricity Authority (CEA). The National Electricity Policy, 2005, laid out, among others, the goal of universal electricity access in the following five years and planned to pursue rural electrification aggressively. ${ }^{19}$ This momentum was carried forward by the launch of the Rajiv Gandhi Grameen Vidyutikaran Yojana (RGGVY) in 2005 (more recently the Deen Dayal Upadhyaya Gram Jyoti Yojana-DDUGJY). The following year, the National Tariff Policy (NTP), 2006, set out its objective to make reliable electricity available to consumers at a competitive tariff to drive down capital costs, improve operational efficiency, and enhance the quality of service. It sought to improve transparency and reduce the perception of regulatory risks. ${ }^{20}$

\subsubsection{Central Government Schemes}

The central government has come out with several schemes that have focused on improving the transmission and distribution infrastructure, as well as enhancing operational efficiency.

DDUGJY focuses on feeder separation (rural households and agricultural) and strengthening of sub-transmission and distribution infrastructure in rural areas. It is meant to provide round-the-clock power to rural households and adequate power to agricultural consumers. The grant under this scheme could be as high as 90 percent of the project cost for 'Special Category' states and 75 percent for others. The discoms can also get an additional grant if they are able to meet certain conditions, including the timely completion of the scheme, reduction in AT\&C losses as per a specified trajectory, and upfront release of revenue subsidy by the state governments based on metered consumption. ${ }^{21}$

While DDUGJY focuses on rural areas, IPDS has an urban orientation. The scheme seeks to strengthen the sub-transmission and distribution network in the urban areas; metering of distribution transformers, feeders, and consumers; and IT enablement of the distribution sector. Discoms can get an additional grant under IPDS too, based on similar conditions as in DDUGJY.22

Launched in 2015, UDAY aims at providing a permanent resolution of the discoms' issues by bringing about an operational and financial turnaround. Under the scheme, states are supposed to take over 75 percent of the discoms' debt, thereby reducing their interest cost, and partly future losses as well. ${ }^{23}$

So far, the scheme has helped the cash-strapped discoms in reducing their debts and the total AT\&C loss. However, it has not been able to address challenges around crosssubsidy and power-procurement costs.

As per the conditions of UDAY, by 2018-19, state governments were supposed to reduce the AT\&C loss to 15 percent and the ACS-ARR gap to zero, ${ }^{24}$ through operational improvements such as compulsory smart metering of large customers, upgradation of distribution infrastructure, and implementing energy-efficiency measures. Unfortunately, notwithstanding a slight dip from 23.96 percent in 2015-16 to 22.03 percent in 2018-19, 
the AT\&C loss figure now stands at 24.54 percent. kWh in 2015-16, rose to ₹ $0.72 /$ kWh in 2018-19vii

The massive Saubhagya scheme mostly succeeded in expediting electricity access across off-grid pockets. However, it could not address challenges around tariff realisation with these new groups of consumers which ultimately impacted the discoms' finances in some states.

In the 2021-22 Budget, the Centre has announced another new scheme to promote the viability of discoms. 'A revamped, reforms-based result-linked power distribution sector scheme will be launched with an outlay of ₹ 3,05,984 crore over five years. The scheme will provide assistance to discoms for infrastructure creation, including pre-paid smart metering and feeder separation, upgradation of systems, etc., tied to financial improvements. ${ }^{25}$

One of the reasons for the schemes' poor performance is the joint funding by the Centre and state governments and/or discoms, where a delay in disbursement by either of the two could put the project on hold. Yet some states (such as Haryana, Maharashtra and Kerala) have managed to leverage these schemes and achieve a degree of sustained turnaround (Exhibit 8).

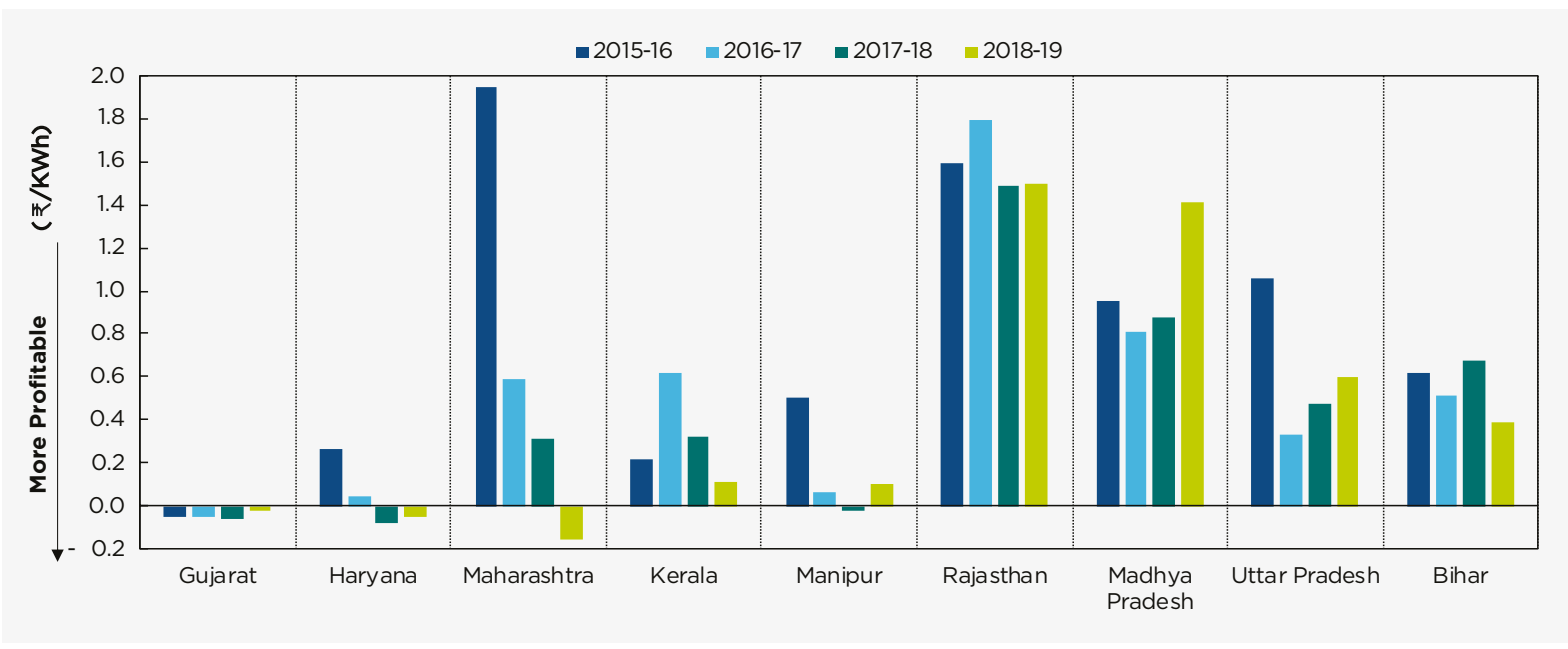

Exhibit 8: ACS-ARR Gap performance of selected states during UDAY period (Source: PFC. See Appendix 2 for details)

The relatively successful states have also coupled these schemes with state-level technology, business models and administrative initiatives tailored to meet their specific needs. Many have initiated state-level schemes, especially with specific capex grants for grid strengthening, connections, solarisation of agricultural feeders, feeder separation, etc.

Geography and consumer mix also affect the success of discom reforms. A geographically big state such as Rajasthan, with a highly rural population, struggles with ensuring better

vi Data for 2015-16 and 2018-19 from PFC. Current data from UDAY portal.

vii This is the ACS-ARR gap calculated on a tariff subsidy received basis, adjusted for regulatory income and UDAY grant, and calculated on Gross Input Energy Basis. Source: PFC reports. 
performance by its discoms. Hilly states, particularly in the north-east, have also had a challenging journey with respect to the reform of their discoms. Limited state and discom capacities, including budget and poor macro-economic conditions, also act as major barriers. With respect to transmission and distribution (T\&D) infrastructure deployment, the central schemes have only been marginally successful in reducing transmission losses. But the loss level has remained considerably high, especially due to poor billing. Arunachal Pradesh, for example, struggles with an AT\&C loss of 56 percent and a billing efficiency of 45 percent. $^{26}$

While schemes can provide some financial respite or enhance the infrastructure, sustained improvement of discoms' profitability continues to be elusive for the country as a whole, as illustrated in Exhibit 9. Any scheme attempting to resolve challenges across all the states must be respectful of the multiplicity of these difficulties.

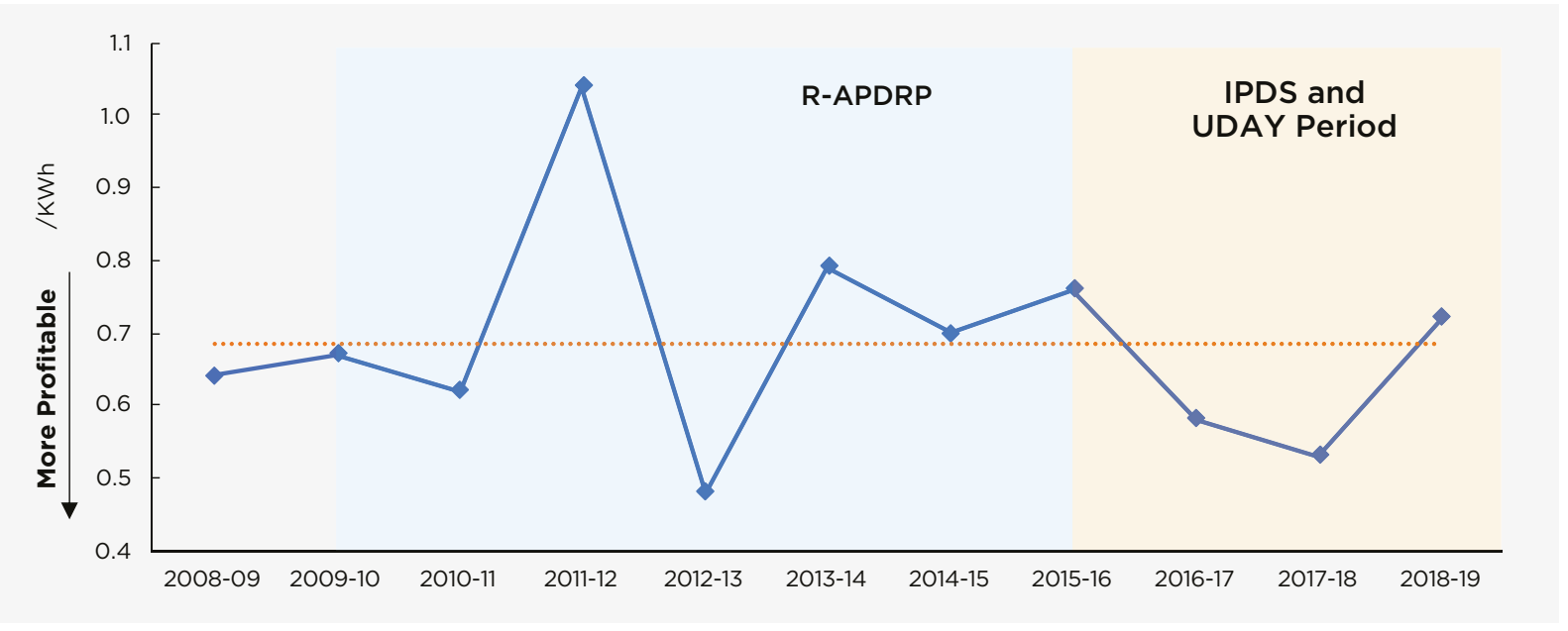

Exhibit 9: India's ACS-ARR Gap journey

(Source: PFC. See Appendix 2 for details)

Apart from these schemes, the Central Government has also sought to promote discom reform through efforts such as the Annual Integrated Ratings of State Power Distribution Utilities. The recently released ninth annual rating assesses discoms on the criteria of operational and reform parameters, external (regulatory and government support) parameters and financial parameters. In this rating, the discoms of Gujarat, Haryana, Punjab and Maharashtra have achieved the highest grades. ${ }^{27}$

\subsubsection{Private Participation and Competition in Distribution}

The partial success of the Electricity Act is that overall the sector has largely been vertically unbundled, with a high degree of competition and private participation achieved in generation. Forty-seven percent of the generation is being privately done as of March 2021.28

Privatisation of discoms has often been seen as a way to improve overall sector efficiency. International experience suggests that privatisation alone is not a panacea for improving discom performance. ${ }^{29}$ In India, too, experience with privatisation has been variable. In areas such as Delhi, Surat, Ahmedabad, Kolkata and Mumbai, private licensees are running 
discoms relatively efficiently. In many areas, distribution franchisees have helped bring down distribution losses significantly. But there have been challenges as well. In Odisha, four discoms were first privatised in 1999. However, the private companies were not able to improve the distribution system or reduce the losses of the sector as per expectations. Ultimately, one of the private companies abandoned the attempt, and the state regulator revoked the licences of the other three. ${ }^{30}$ India has also seen multiple cancellations of franchisee contracts in states such as Maharashtra, Madhya Pradesh, Uttar Pradesh, Rajasthan and Jharkhand ${ }^{31}$ (see sections 2.1.2 and 2.1.3).

Channelling private investment in distribution remains a challenge. There is a perception of loss-loss of jobs of discom employees, loss of the welfarist nature of state-owned discoms that sustain the residential and agriculture sectors on subsidised tariff, loss of the ability to serve the poor and the vulnerable, and loss of jurisdictional authority for states where the Centre proceeds with this decision without adequate state buy-in. These have come to light most recently in the wake of the announcement of privatisation of all Union Territories' discoms as well as that of some states including Uttar Pradesh. In the case of the latter, protests by employees of Purvanchal Vidyut Vitran Nigam Ltd (PVVNL) against its privatisation were fuelled primarily by the fear of potential job losses. ${ }^{32}$

At the core of the challenge to privatisation is the question of its promise of success. The transformation of Delhi Vidyut Board (DVB), for example, by unbundling and sale of majority stakes to Tata Power and BSES, is often cited as a model of successful privatisation. Importantly though, consumer mix in Delhi is relatively homogenous-with a marginal agricultural sector and a largely middle-class residential sector with a high demand for efficiency. ${ }^{33}$ The transition of Delhi's discoms was supported by government subsidy, and all DVB employees were transferred to the new companies with benefits, thereby offering job security. However, this landscape is not representative of the rest of the country. The Union Territories might be exceptions, given their small, concentrated geographies and direct jurisdiction by the Centre.

Furthermore, privatisation becomes more difficult when the discom's service area is more rural. Given the tariff differential and difficulty of billing, collection, and, in some cases, metering, the cost of servicing rural and agricultural consumers becomes commercially challenging. When the business of wires and supply can be segregated in some form from the business of billing and collection, some degree of private capital can be attracted through models such as the franchisees. But for full-scale privatisation, the consumer mix and geography will ultimately be factors in achieving commercial viability.

Thus, the political economy of electricity with its multiplicity of stakeholders and interests, the drastic difference in demand, needs, and ability to pay off rural and urban consumers, as well as the imperative of state welfare are what make distribution privatisation so challenging.

The central government has recently declared its intent to delicense power distribution and promote competition among discoms. ${ }^{34}$ Multiple firms can compete to supply power through the same grid infrastructure, and consumers can choose the supplier who provides them the best quality-cost combination. This reform can be challenging to get right and should be accompanied by careful market design. 
The need for a low-carbon and climate-resilient future, makes it crucial for the Indian electricity distribution sector to achieve operational efficiency, profitability, and a readiness for emerging and future demand as well as technological changes. With lessons from the past two decades of reforms, insights from international best practices, combined with continued government commitment to transform the power sector, discoms can embark on their path to profitability. 


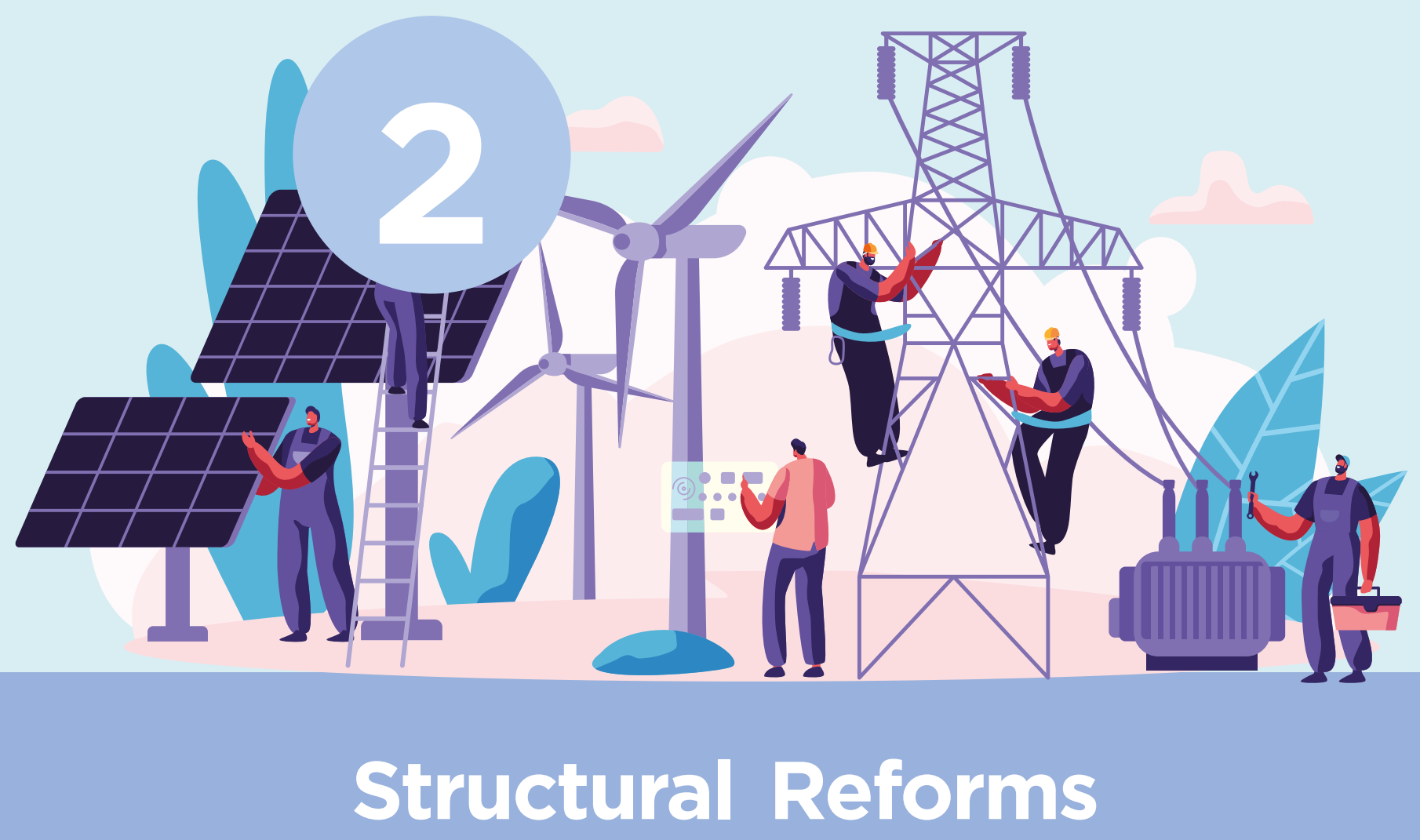

The institutional architecture of the distribution sector is critical for the viability of electricity market. Structural reforms in this sector include the vertical unbundling of the power sector actors, introducing privatisation models for discoms, and promoting horizontal unbundling of the power market.

\subsection{OWNERSHIP MODELS}

Globally, 70 percent of distribution utilities are publicly owned. The remaining 30 percent of the privately owned companies are located primarily in middle and high-income countries. ${ }^{35}$ The vast majority of consumers in India continues to be served by stateowned utilities.

Private participation in distribution has been limited to few urban centres and townships across the country. Private participation in the distribution sector has been dominated by two models-licensee model and franchisee model-as summarised in Table 2.

Table 2: Two prominent models of private participation in electricity distribution in India

\section{Distribution Franchisee Model}

Private party has no ownership over the distribution grid assets.

Private party manages billing and revenue collection mainly.

Example - Torrent Power, Bhiwandi, $\mathrm{MH}$

\section{Distribution Licensee Model}

Private party holds equity and is part or complete owner of the distribution grid assets.

Private party manages the distribution of power along with billing and revenue collection services.

Example - TATA Power, New Delhi 


\subsubsection{State Ownership}

Most discoms in India are state-owned, with private utilities serving only 10 percent of the consumers in the country. ${ }^{36}$

A World Bank study found that most utility boards remain state-dominated and lack sufficient decision-making authority. ${ }^{37}$ However, some state-owned discoms have witnessed a successful turnaround due to purposeful restructuring and empowered governance that have improved long-term decision-making. A key attribute of these discoms is improved public administration, with strong leadership and steady tenures. The World Bank study found that discoms with greater autonomy and higher quality corporate governance are more profitable. ${ }^{38}$ The performance of discoms is also determined by the proactive role of regulators in providing timely tariff updates for maintaining the financial sustainability of the sector.

\section{Box 1: Where have public discoms worked in the world?39, 40}

A review of global cases of successful public ownership of electricity distribution shows that public discoms rooted in community participation/ownership and financial and regulatory independence have shown some success.

The independence of regulatory bodies is crucial to the financial health of utilities since they have the power to set (cost-reflective) tariffs. Independence and certainty in regulation also help allay any concerns that potential investors may have. This has been seen in the success experienced by the power sectors of Latin American countries such as Costa Rica and Uruguay, whose sectors are primarily state-owned but they foster private sector participation successfully as well.

Interestingly, a trend towards municipalisation or remunicipalisation is being seen in some countries such as the USA and Germany. In Germany, for example, after a spate of privatisation of municipal utilities in the 1990s, communities chose not to renew their contracts with private utilities. They instead chose to renationalise municipal utilities (Stadtwerke), showcasing faith in the public sector to address market deficiencies.

\subsubsection{Distribution Franchisee Model}

The distribution franchisee (DF) model allows state-owned discoms to use private parties to perform specific functions, without the transfer of ownership. The attractiveness of this model lies in the potential for a rapid reduction in technical and commercial losses and adoption of better operational and management practices. Additionally, given the absence of obligation for direct asset ownership, it also becomes easier to attract private investment, compared to the licensee model.

Bhiwandi in Maharashtra is a shining example of the success of this model, given the sustained improvement in performance on all fronts over its baseline. The fact that Bhiwandi is an urban setting attracted bids from multiple private parties. Torrent Power eventually won the bid. The success of this franchisee further encouraged the Maharashtra State Electricity Distribution Company Limited (MSEDCL) to replicate this model in 
other areas. ${ }^{41,42}$ Feedback Energy Distribution Company (FEDCO) has had success with this model in Odisha. It has been replicated in other states such as Meghalaya, Tripura, Rajasthan and Madhya Pradesh. ${ }^{43}$

\section{Box 2: A Distribution Franchisee Model in Odisha ${ }^{44}$}

Odisha was the first state in India to privatise its discoms in 1999. The first attempt at privatisation failed when the distribution licensees operating with CESU-AES Corporation and BSES-couldn't pay their power dues a few years post operation. The overall AT\&C losses remained above 38\%, resulting in cumulative losses of over $\$ 250$ million in 2012-13.

With no financial institution willing to lend money to CESU in 2012 and insufficient revenues, CESU decided to implement the input-based franchisee with incremental revenue sharing (IBF-IRS) model, where the franchisee would infuse the capital required for system upgrades and the incremental revenue generated would be shared between CESU and franchisees in a mutually agreed ratio.

CESU engaged FEDCO as a franchisee in four divisions in 2013. FEDCO achieved an average 23\% reduction in AT\&C losses between 2013 and 2017. The overall collection doubled in the same period as well. They also managed to bring down the power purchase cost below the revenue collection. FEDCO claims this to be the steepest reduction in AT\&C losses achieved in a predominantly rural area.

\section{AT\&C Loss Reduction by FEDCO in Odisha}

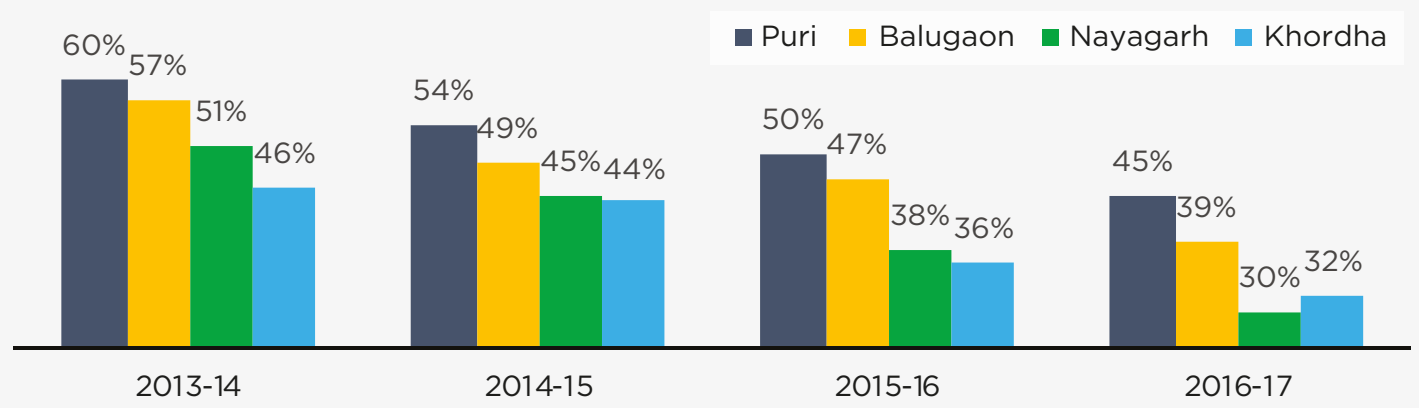

Recently, Tata Power has taken over the management and operations of five discoms in Odisha, having won the bids for the licenses.

However, India has also seen multiple cancellations of DF contracts, including in Aurangabad, Nagpur and Jalgaon, ${ }^{45}$ due to non-payment of dues, and in states such as Madhya Pradesh, Uttar Pradesh, Rajasthan and Jharkhand. These cancellations have brought to light the need for provision of transitional support, and a favourable policy environment in ensuring success of this model. ${ }^{46}$ Clear legal and policy frameworks are needed to avoid issues such as delays in takeover of franchisee areas as well as postbidding dilution of contracts as in the cases of Bhiwandi, Kanpur and Agra, observed between 2007 and $2012 .{ }^{47}$ DF is also not immune to the larger political issues surrounding 
the sector. For example, enforcing cost-reflective tariffs and streamlining billing and collection processes can see resistance from some consumer quarters, as was the case with Essel Utilities in Madhya Pradesh. ${ }^{48}$ However, discoms have been able to mitigate some of these risks as a result of experiential learning; this model has been mostly successful since 2015.

Depending on the level of functions, the DF model can be classified into three groups: (i) input-based distribution franchisee (IBDF), (ii) revenue franchisee/collection-based distribution franchisee (CBDF); and (iii) outsourcing.

IBDF involves the DF procuring electricity from the licensee (usually state-owned discoms) at a predetermined input rate. The DF's role is to bill and collect effectively, such that any surplus generated beyond the payment for the electricity purchased becomes the commercial profit for the DF. They also undertake some capex commitment, at times with contribution from the state government-this can enable efficiency and reduce losses. In some models, some form of asset management roles are also performed by the DF, which provides room for technical loss reduction beyond billing and collection. ${ }^{49}$

In CBDF, the role of the DF is limited to billing and improving collection. Success in this group is linked to monthly revenue generation and improving billing, collection, complaint redressal mechanisms, etc.; it is not tied to the reduction of loss in input energy. Power procurement, which makes up 75-80 percent of the total distribution cost, remains the responsibility of the distribution licensee. The CBDF model is currently running in Assam.

The outsourcing model involves direct outsourcing of discom functions-mainly billing and collection-at a flat margin, without performance-based incentives. Such contracts come in the form of management operator and service operator models, such as those in West Bengal, Bihar, Uttar Pradesh and Maharashtra.

States such as Andhra Pradesh ${ }^{50}$ have experimented with the concept of rural electric cooperative societies (RESCOS), where the ownership and maintenance of assets and provision of services are the responsibilities of the members of the cooperative. RESCOs as a model need to be assessed further, given the success they enjoyed in countries such as the USA where a total of 930 rural cooperatives (864 distribution ones) are currently serving 42 million people in 47 states. $^{51}$ Similar models, such as Smart Power India (SPI)'s model distribution zone (MDZ) programme in Odisha, have also emerged where a network of women self-help groups has helped improve billing, collection, and customer care for grid-tied households. MDZ was able to reduce losses and increase incremental revenue for CESU, the utility. ${ }^{52,53}$

Although DF models show promise, their impact on strengthening overall systems and in reducing losses is limited, depending on the specific DF model, the relationship with the state machinery, and the rural/urban nature of the landscape. Given the limited control that DFs have on distribution system operations, tariffs, and cost of supply, their ultimate impact on transforming the sector is limited. DFs have minimal incentive or ability in the form of capital investments to enable innovation. Lastly, the model also faces a degree of long-term risk from grid-modernisation efforts, especially from smart grids, if its performance incentives remain tied to billing and collection only. 


\subsubsection{Distribution Licensee Model}

In this model, the private party owns the distribution assets and performs all distributionrelated functions-from the purchase of power from suppliers of its own choice and supply to end users, to billing and collection. In urban areas, where there is a high density of population and a reasonably homogenous consumer mix, private parties might be more enthusiastic about acquiring an existing state-owned utility. Industrial areas are also suitable candidates for privatisation.

Depending on the financial viability, privatisation could be complete (100 percent ownership by the private party) or partial, with the government retaining a minority stake in the utility. In either case, the management control resides with the private owner. This model was successfully implemented in places such as Delhi, Ahmedabad, and Surat. The Power Ministry has recently issued draft bidding documents for this model of private participation. ${ }^{54}$

The transformation of DVB, by unbundling and sale of majority stakes to Tata Power and BSES, is often cited as a model of successful privatisation. The billing and collection efficiencies of TPDDL in Delhi are 92 percent and 100 percent, respectively, leading to an aggregate AT\&C loss of just 8 percent, far lower than the 22 percent AT\&C loss of all public utilities (see Appendix 4 for the details). The transition of the Delhi discoms was supported by government subsidy, and also the transfer of all DVB employees to the new discoms with benefits, thereby ensuring job security. Importantly though, the consumer mix in Delhi is relatively homogenous, with a marginal agricultural sector and a largely middle-class residential sector, with a high demand for efficiency. It must be kept in mind that this landscape is not entirely representative of the rest of the country.

While the private distribution licensee model provides greater ownership and control over improving the system, it is relatively more financially demanding for the private sector. The model has been successful in major cities such as Delhi and Surat where government support, consumer mix and geography helped it succeed. Furthermore, privatisation becomes difficult to achieve when the discom service area is more rural. Given the tariff differential and difficulty of billing, collection, and, in some cases, metering, the cost of servicing rural and agricultural consumers is commercially challenging. For fullscale privatisation, the consumer mix and geography are ultimately factors in achieving commercial viability.

The case in point was the attempt made at privatisation in Odisha (Box 2), where the contracted licensee, CESU - AES Corp, eventually had to give way to a franchisee model led by FEDCO. FEDCO's performance on loss reduction, on the other hand, has been reasonably impressive, even in rural areas, making the case for the franchisee model even in less urban geographies. Tata Power has recently taken over as the distribution licensee for Odisha. ${ }^{55}$

Recently, the government has declared its intent to delicense the distribution sector. ${ }^{56}$ This is meant to promote competition in the industry (see Section 2.3.3). 


\subsection{VERTICAL UNBUNDLING}

Table 3: Discom structure in states

\begin{tabular}{|c|c|c|c|c|}
\hline $\begin{array}{c}\text { Vertically } \\
\text { Integrated-Power } \\
\text { Department }\end{array}$ & $\begin{array}{l}\text { Transmission } \\
\text { separation-GEDCO } \\
\text { (Generation \& } \\
\text { Distribution Co) }\end{array}$ & $\begin{array}{l}\text { Unbundled } \\
\text { with Single } \\
\text { Public } \\
\text { Discoms }\end{array}$ & \multicolumn{2}{|c|}{$\begin{array}{c}\text { Unbundled with Multiple Public } \\
\text { Discoms and/or Private Licensee } \\
\text { / Franchisee }\end{array}$} \\
\hline Arunachal Pradesh & Himachal Pradesh & Assam & Andhra Pradesh & Maharashtra*\# \\
\hline Goa & Kerala & Chhattisgarh & Bihar & Odisha*\# \\
\hline Jammu \& Kashmir! & Manipur & Jharkhand & Delhi\# & Rajasthan* \\
\hline Mizoram & Punjab & Meghalaya* & Gujarat*\# & Uttar Pradesh"\# \\
\hline Nagaland & Tamil Nadu & Uttarakhand & Haryana & West Bengal ${ }^{*} \#$ \\
\hline Puducherry & Tripura" & & Karnataka & \\
\hline Sikkim & & & Madhya Pradesh & \\
\hline $\begin{array}{l}\text { Note: } \\
\begin{array}{ll}* & \text { indicates presen } \\
\# & \text { J\&K'S GENCO wo }\end{array}\end{array}$ & $\begin{array}{l}\text { of private franchisee } n \\
\text { set up as a private lim }\end{array}$ & $\begin{array}{l}\text { del; \# indicates } \\
\text { d company. }\end{array}$ & resence of private lic & nsee model, \\
\hline
\end{tabular}

Vertical unbundling has progressed quite well on paper-most states have unbundled their power utilities (Table 3). However, actual separation and functional independence of generation, transmission, and distribution may be less than they appear. For instance, state-owned discoms may prefer to purchase power from state-owned generators, even if they can purchase cheaper power from elsewhere. ${ }^{57,58}$

\subsection{HORIZONTAL UNBUNDLING}

Horizontal unbundling-related reforms can produce significant operational and financial efficiencies for discoms by enabling flexibility in short-term power procurement through power markets. Horizontal unbundling can also empower consumers by offering them a choice of more than one supplier of electricity. These reforms have already started to take shape but face roadblocks that can prevent their complete realisation.

\subsubsection{Unlocking Short-Term Power Markets}

Horizontal unbundling has generated cautious optimism in the area of power procurement, given the success of privatisation of the function of generation, introduction of short-term markets through the Discovery of Efficient Electricity Price (DEEP) viii mechanism, and the advent of the wholesale power market (see Box 5). Yet, the current state of power procurement remains enmeshed in the many long-term PPAs, limiting

viii DEEP is an e-Bidding and e-Reverse auction portal for procurement of short-term power by Discoms. Shortterm procurement could be from a period of more than one day up to one year. Power plants that do not have PPAs today are now allowed coal linkages between three months and one year, if they sell in the DAM or DEEP. 
the utility of market reforms. This restricts discoms' ability to procure low-cost power available at the power exchange or sign up for low-cost RE power.

Based on over-optimistic projections of power demand, discoms committed themselves to expensive and long-term thermal PPAs ${ }^{59}$ which consist of two parts (fixed and variable). Discoms incur fixed costs regardless of the power consumed by their end customers. For a few states, such as Maharashtra, Rajasthan and Madhya Pradesh, these costs make up more than 30 percent of the total contracted power purchase cost. ${ }^{60}$ States such as Chhattisgarh, Gujarat, Maharashtra and Uttar Pradesh have banned new thermal PPAs till $2022^{61}$ and discoms have been given the liberty to procure electricity from the exchange during seasonal peak loads.

\subsubsection{Open Access}

The concept of open access (OA) was introduced in the EA 2003. OA promotes competition by allowing large consumers (> 1MW) non-discriminatory access to suppliers of power other than the discoms.

After EA 2003 was passed, the CERC and the SERCs notified regulations allowing procurement of power through OA. However, varying state policies, high OA charges, and procedural hurdles imposed by discoms have led to the slow progress of OA. Even so, OA and captive sales have increased rapidly.

Given the cross-subsidy regime in the country, discoms stand to lose out on higher paying customers if the OA regime is widely utilised. While the Act requires that cross-subsidies and surcharges be progressively reduced and eliminated, they have been increasing over the last few years. ${ }^{62}$ In this light, reforms such as tariff rationalisation become even more important (see section 3.1.1), as OA becomes more widespread.

\subsubsection{Consumer Retail Choice}

While vertical unbundling has had some degree of success, when it comes to horizontal unbundling and providing choice to the consumer, the sector has been struggling. Even where discoms are privatised, each one (licensee or franchisee) still has a monopoly over its service area, thus limiting any real retail competition. 


\section{Box 3: Expanding consumer retail choice via rooftop solar}

Related to OA and indirect consumer choice is the rooftop solar (RTS) programme. As a DER, RTS helps reduce transmission and distribution losses, as generation and distribution are co-located. It offers large consumers such as the commercial and industrial (C\&I) ones options to optimise costs and releases them from the burden of high tariffs for cross-subsidisation. They can also source solar electricity from the OA route or third-party developers who supply power to the market. Smaller consumers ( $<1 \mathrm{MW}$ ) such as those in the residential sector also stand to benefit from RTS by being able to access reliable electricity and get compensated for the sale of surplus electricity back to the discoms under net or gross metering arrangements. Additional benefits to the discoms include availability of more RE to fulfil their renewable purchase obligations (RPOs).

The central government's recent Budget announcement on promoting consumer choice and avoiding discom monopoly has the potential to overhaul the power distribution sector. $^{63}$ The separation of content (retail electricity) and carriage (wires) is the proposed means of creating retail customer choice in India. In global markets, this is typically referred to as retail choice. Once this separation is achieved, there could be multiple firms (called distribution companies) supplying power through the same grid infrastructure. Consumers can choose the supplier who provides them the best quality-cost combination. However, this reform can be challenging to achieve, and should be accompanied by careful market design.

In India, such a system already exists in Mumbai which has had a long tradition of electricity supply by private companies. Most of the cables are underground and losses are low. ${ }^{64}$ Even so, competition in distribution is not very successful. Consumers who want to change suppliers face heavy regulatory charges and surcharges, making it unviable for them to migrate. Also, the high level of cross-subsidies shouldered by C\&I consumers entices suppliers to cherry-pick high-paying consumers. ${ }^{65}$

Mumbai offers us several insights into the complex problem of operationalising retail choice. There needs to be clear criteria governing entry and exit of players. There should be regulatory clarity on the many complex questions that are important for implementing retail choice. Regulations will need to underpin a fair and non-discriminatory access regime to the distribution grid. Competition in distribution will also require greater clarity on aspects such as the duty to provide supply and cost-plus tariff regulation. ${ }^{66}$ 


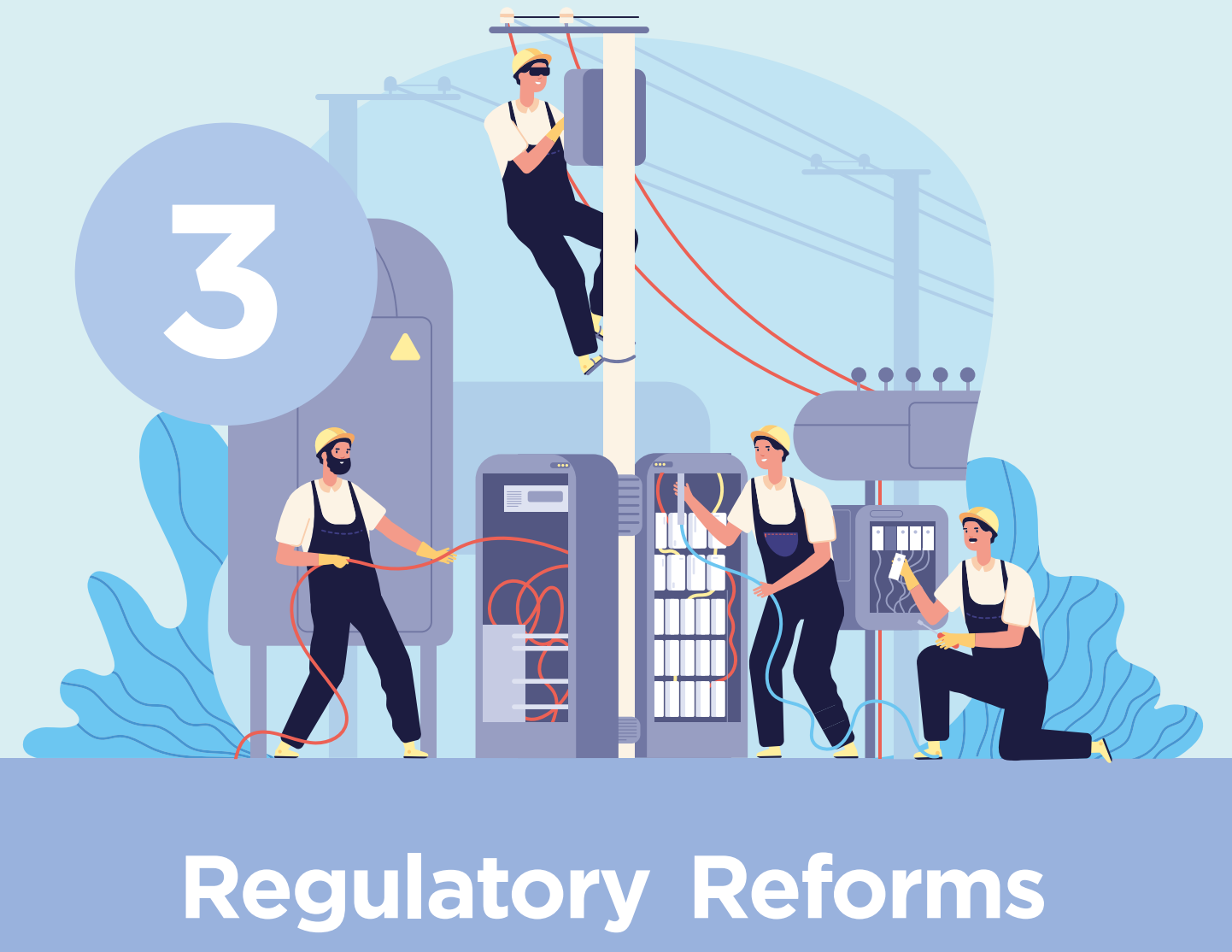

\subsection{ROLE OF STATE REGULATORY COMMISSIONS}

The establishment of CERC and SERCs was an important step in reforming the governance of the power sector. It signalled the move towards regulatory independence. But true autonomy remains elusive. A study done by the World Bank found that SERCs' ability to carry out their mandate under EA 2003, with limited political interference, has a significant positive association with profit per unit of electricity. This underlines the importance of a robust regulatory framework for utility operations. ${ }^{67}$

The study found that many SERCS are yet to implement adequate transparency measures or create frameworks for meaningful public input to the regulatory process. Beyond these deficiencies, there are also no clear accountability mechanisms to govern the SERCs. Unless these gaps are addressed, the SERCs' ability to create an independent, transparent, and unbiased governance framework to balance the interests of consumers and discoms will remain muted. ${ }^{68}$

\subsubsection{Tariff Setting}

Low electricity tariffs are not just an Indian problem. It is commonly observed in developing countries that electricity tariffs are rarely high enough to cover the full costs of service delivery. ${ }^{69}$ At the heart of the tariff rationalisation debate is the tension between two different outlooks: is electricity an essential public service whose provision at low rates is essential for public welfare, or is it a commodity to be bought and sold in the market like any other? States have chosen to locate themselves at different points on the policy 
spectrum between these two extreme stances. While the right of the states to choose their policy stance is sacrosanct, the problem arises when discoms are unable to fulfil their obligations to their consumers and suppliers.

An aspect related to welfare is the growth in energy access. Although the Saubhagya scheme was successful in achieving 100 percent electrification by 2019, it expanded the base of low-paying customers on the grid which contributed to the rapid rise of the state-subsidy burden.

States such as Delhi and Gujarat ${ }^{70}$ are good examples where tariff rationalisation has been carried out using the following principles:

" Adjusting the two-part tariff to accurately reflect the actual fixed and variable costs to prevent underrecovery of fixed costs.

" Quarterly tariff adjustments to ensure timely recovery of variable costs.

" Simplifying the tariff structure by minimising customer categories and tariff slabs.

Similarly, the rise in electricity volumes being generated through captive power and being traded on OA platforms, poses revenue realisation challenges for discoms still functioning in the context of cross-subsidisation.

\subsubsection{Regulatory Assets}

Often SERCs do not increase tariffs to match the increasing costs of discoms, in order to shield consumers from tariff shocks. The higher costs have to be absorbed by discoms. However, they are recognised by the regulator as regulatory assets, to be recovered through future tariff hikes. The appellate tribunal had earlier ruled that regulatory assets must be recovered over three years. However, the magnitude of the assets could cause a major tariff shock..$^{71}$ Therefore, the recovery was spread over a longer period, with no relief to discom finances.

Mounting regulatory assets create cash-flow problems for discoms, forcing them to borrow funds to cover the revenue deficit. The additional borrowing, coupled with the interest, adds to the burden of discoms. Post the Covid-19 lockdown, it is feared that the regulatory assets will increase to as much as $₹ 90,000$ crore. $^{72}$

Several states have dealt effectively with regulatory assets overhang. For instance, regulatory assets in Delhi have reduced by over $₹ 3,000$ crore in a span of five years due to reduced AT\&C losses via upgradation of transmission and distribution infrastructure and purchase of low-cost RE power. ${ }^{73}$

\subsection{DIRECT BENEFIT TRANSFER}

DBT is part of the Government of India's initiative to reform subsidy provision and dissemination to improve transparency and reduce leakages. Subsidies are transferred directly to a citizen's account instead of distorting the market prices for commodities or services. Redesigning power subsidy using DBT is a pilotable approach that can achieve welfare goals while being less distortionary (see Box 4). 


\section{Box 4: Paani Bachao Paise Kamao - Direct Benefit Transfer meets Behavioural Energy Efficiency and Smart Water Pump ${ }^{74}$}

The Paani Bachao Paise Kamao scheme has been conceived by MIT's Abdul Latif Jameel Poverty Action Lab (J-PAL) in collaboration with the World Bank. It is being piloted in Punjab with the discom Punjab State Power Corporation Limited (PSPCL) as the implementation agency and The Energy and Resources Institute (TERI) as the nodal body. It is supported by Punjab Agricultural University (PAU) and IT Power India (ITPI).

The pilot scheme aims to address the issue of agricultural groundwater overconsumption by incentivising farmers to reduce their electricity and water use without disturbing their free electricity provision. Farmers are positively reinforced to consume less than their free allocation by giving them rebates against their bill for lower consumption. Overconsumption is not charged. Electricity is supplied only during daytime, which allows farmers to monitor their water consumption.

Enrollment is voluntary but once enrolled, an automated meter reading (AMR) system is installed at their agricultural pump connection. AMR enables the discom to monitor energy consumptions and calculate savings and incentives. Consumptions and saving data are conveyed to farmers through SMS on a bimonthly basis. Any incentive amount is credited to farmers through a DBT mechanism.

Success on the first six feeders has prompted the state to extend the pilot to 250 additional feeders.

Under DBT, subsidies are transferred directly to a citizen's bank account or discommaintained consumer bank accounts. The electricity bill is assessed on the basis of true cost rationalised tariff or within the stated maximum of 15 percent cross-subsidy. Transitioning to DBT will improve revenue realisation and enable discoms to implement ToD and other best practices in consumer engagement. The DBT scheme holds significant benefits for discoms but requires closer coordination among the state government, the SERCs, and the discoms, for its successful deployment (see Table 4). 
Table 4: Summary of DBT Scheme

\begin{tabular}{|l|l|l|l|}
\hline \multicolumn{1}{|c|}{ Solution Option } & $\begin{array}{l}\text { Technical Issues } \\
\text { Addressed }\end{array}$ & \multicolumn{1}{|c|}{$\begin{array}{c}\text { Business Issues } \\
\text { Addressed }\end{array}$} & $\begin{array}{c}\text { Managerial Issues } \\
\text { Addressed }\end{array}$ \\
\hline $\begin{array}{l}\text { DBT \& cost } \\
\text { rationalisation of } \\
\text { tariff }\end{array}$ & - Cost-reflective tariffs & \\
\hline & - Revenue realisation \\
& - High-cross subsidy & \\
\hline
\end{tabular}

- DBT increases discom revenues realised through cost-reflective tariffs and bills that are paid on time. Further, DBT can decrease the cost of service by enabling discoms and customers to optimise demand to match lower cost supply through ToD rates and more advanced tariff programmes.

- Efficiency: DBT allows discoms to send proper price signals to large numbers of customers that can result in more efficient use of resources and create opportunity to use time and location-based price signals to optimise operations and increase efficiency.

- Discom Finance: DBT will eliminate large delays in discom revenue if state governments are able to deposit subsidy into accounts on a timely manner.

\section{How to make it work}

- Discoms: Installing meters and implementing billing programmes are required to capture the full set of benefits that DBT provides for discoms.

- Discoms and SERCs: To capture the major benefits of DBT, the transition of subsidy must be implemented in a parallel manner with revised tariffs and a new paradigm of annual tariff revision to match cost and inflation. This could also include a reassessment of customer's willingness to pay.

- State Government: The livelihood of the end customer receiving DBT will be dependent on the timeliness of the DBT being funded. If funds are deposited directly to the customer's account managed by the discom, it is necessary that considerations be made on if and when to disconnect power to the customer if the state delays DBT payment. If delays in DBT funding happen, the financial stress is moved from the discom to the customer which is not the intended outcome. 


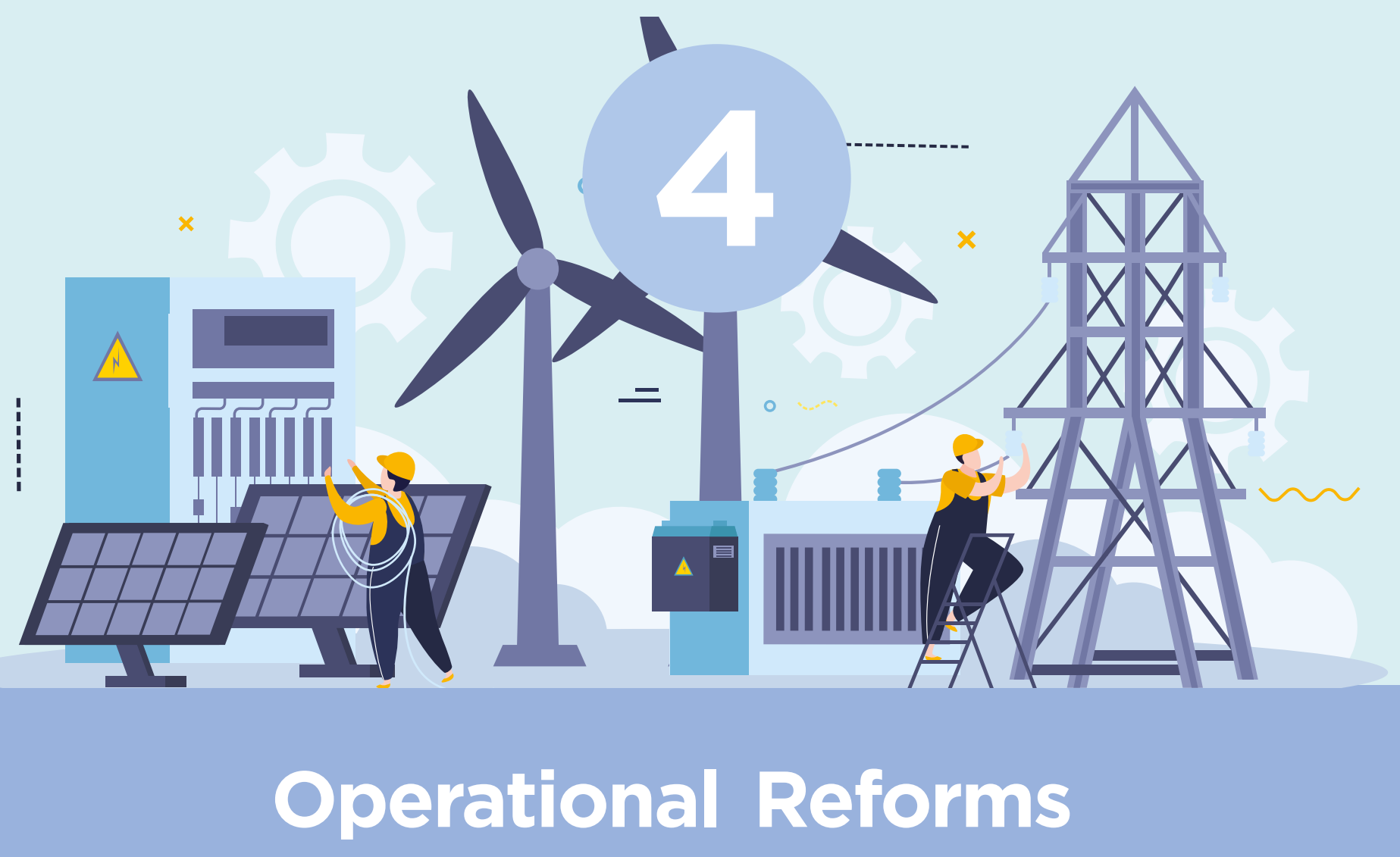

This section provides a review of different techno-policy solutions that can address a suite of different technological, business, and managerial challenges that discoms face today and will continue to face in the future. Experimentations, piloting, and policy derisking through financial and non-financial means are crucial to enabling these solutions.

\subsection{POWER PROCUREMENT COST OPTIMISATION}

Power procurement accounts for almost 80 percent of the expense of the discoms. Discoms have oversubscribed to expensive and long-term thermal PPAs based on incorrect estimates of power demand. The fixed costs of the excess capacity must be paid, even when no power is generated. This has led to a high cost of power, insufficient investment in infrastructure, and payment delays to generators. ${ }^{75}$ The Forum of Regulators has calculated in a study of 12 states that they are paying $₹ 17,442$ crore annually as the fixed cost for surplus energy. ${ }^{76}$

One way to reduce the cost of power is to use power markets. Over the last decade, transactions in the short-term power market have witnessed an annual growth rate (CAGR) of 8 percent, even though the power generation growth rate reduced to 6 percent during the same period. Electricity traded through power exchange has witnessed a rapid growth of 23 percent annually and is primarily responsible for the growth of the shortterm power market. The robust growth of DAM and RTM indicates discoms' preference to move towards short-term power procurement contracts instead of the traditional long-term PPAs. ${ }^{77}$ 


\section{Box 5: The evolution of the wholesale power market ${ }^{78,79}$}

While power procurement is still largely tied to long-term bilateral PPAs (88\%), there has been a slow but healthy growth in the wholesale markets. Short-term power purchase through power exchanges increased from $0.4 \%$ in 2009 to $4 \%$ in 2019. To strengthen the wholesale market, India recently launched the real-time electricity market (RTM) on June 1, 2020 at the India Energy Exchange Limited (IEX) and the Power Exchange India Limited (PXIL) wholesale market platforms. This is in addition to the existing products: Day-Ahead Market (DAM), Term-Ahead Market (TAM) and Renewable Energy Certificates (REC).

The RTM is designed as a half-hourly market with 48 auction sessions of 15-minute duration. By narrowing the trading window, RTM promised to provide buyers and sellers an opportunity to correct any mismatch of demand and supply closer to delivery, thereby enabling discoms to manage demand variation more efficiently. For generation companies, RTM provides the ability to optimise and sell power surplus better while improving the ability to manage renewable intermittency. RTM even permits generators with long-term PPAs to participate allowing them to sell any unanticipated surplus generation. RE generators can also obtain RECs from any unanticipated surplus generations.

The introduction of Green Term Ahead Market (GTAM) on September 1, 2020, which allows RE developers to sell green power in the open market without the need for long-term PPAs, has already seen a significant uptake by discoms. Electricity scheduled through the GTAM also contributes to the RPO compliance of the buyer.

An important intervention by the Centre around power procurement for states is taking shape in the form of market-based economic dispatch of electricity (MBED), ${ }^{80}$ where all power transactions, including the purchase and sale of power through fixed long-term PPAs, would be routed through the power exchange. This can reduce the variable cost of power (though the fixed costs would continue to be payable) and reduce the requirement of PPAs in the future (see Table 5). Andhra Pradesh saved ₹2342 crore by optimising the procurement of power (including purchasing power from the open market) in the two years $2019-21 .{ }^{81}$ 
Table 5: Summary of Short-term Power Markets

\begin{tabular}{|l|l|l|l|}
\hline \multicolumn{1}{|c|}{ Solution Option } & $\begin{array}{c}\text { Technical Issues } \\
\text { Addressed }\end{array}$ & $\begin{array}{c}\text { Business Issues } \\
\text { Addressed }\end{array}$ & $\begin{array}{c}\text { Managerial } \\
\text { Issues } \\
\text { Addressed }\end{array}$ \\
\hline $\begin{array}{l}\text { Real-time market, } \\
\text { ancillary markets, DER } \\
\text { participation }\end{array}$ & $\begin{array}{l}\text { - Grid stability } \\
\text { - RE integration }\end{array}$ & High APPC & $\begin{array}{l}\text { RE purchase } \\
\text { obligation }\end{array}$ \\
\hline
\end{tabular}

\section{Benefits to Discoms}

- Increase in low-cost flexible supply and demand management through fast responding distributed energy resource management.

- Opportunity and incentive to optimise generation and supply-side dispatch of a wide range of available resources that are currently underutilised (e.g., BTM solar, storage, EVs, etc.)

- Customer participation.

\section{How to make it work?}

- CERC: Develop and implement wholesale products for ancillary services that are inclusive of DERs and aggregated resources.

- Discoms, Gol, Generators: Implement a plan to fairly and effectively transition from longterm bilateral PPAs to increased use of power markets and creation of a liquid market.

- Build consensus across the Centre and states to create common roadmap among Centre, state, and system operators.

Even with the growth of renewable energy, thermal power plants will continue to supply base load, and ways to reduce the cost of thermal power need to be considered. The National Institute for Advanced Studies (NIAS) has suggested a transition plan under which older and inefficient thermal plants can be progressively retired. Their output can be replaced with newer high-efficiency low-emissions (HELE) thermal plants and nuclear plants that are in an advanced stage of construction. This will reduce the idling charges that discoms pay for these underutilised new power plants while reducing energy charges as well. ${ }^{82}$

In a report by Daljit Singh and Ashwini Swain, it was suggested that the discourse needs to move from just power procurement to resource planning. It is a broader process that can be used by discoms to meet the forecasted peak demand and total energy requirements of all their customers over a long-term horizon, typically 10-20 years.

The output of a resource planning exercise is an Action Plan that lists all the actions that need to be taken over the plan period such as capacity additions that need to be made; power purchases that need to be made; and other actions such as programmes to be initiated to improve energy efficiency of consumers. ${ }^{83}$

\subsection{METERING AND BILLING}

Currently, the billing efficiency at the national level is 83 percent. Smart and prepaid meters can be an important component of the solution to billing and collection challenges. Smart meters increase the efficiency of the billing and collection process by reducing human intervention and consequently empowering both consumers and discoms. 
The National Smart Grid Mission (NSGM) has helped build confidence in the technology through pilots on: the impact of smart metering on AT\&C losses; communication standards; consumer acceptance and regulatory hurdles. Services such as billing using Advanced Metering Infrastructure (AMI), ix peak load management, power quality management and outage management were also piloted. AT\&C loss reduction met targets and went as high as 17 percent. $^{84}$

MoP's Smart Meter National Programme (SMNP) aims to replace the country's 25 crore conventional meters with AMIs. SMNP has been conceived as a build-own-operate-transfer (BOOT) model, with Energy Efficiency Services Limited (EESL) as the implementing organisation. By November 2020, EESL had already installed 14.5 lakh smart meters. ${ }^{85}$ So far, most smart meters have been installed in the states of UP, Madhya Pradesh, and Manipur. Manipur has effectively used prepaid meters to curb the usage of electricity illegally. ${ }^{86}$ The prepaid smart meter is a major component of the revamped discom reform scheme proposed in the 2021-22 Budget. $^{87}$

Smart meters also hold other benefits for the system. They are the first step to implement a smart grid-an electrical grid with automation, communication, and IT systems that can monitor and control power flows in real time. ${ }^{88}$ Such a revamped distribution systemwith smart meters, DMS, and other IT/OT components, including SCADA-creates data transparency, improved analytics, better and more granular tariff design, and more control of demand management. These benefits can substantiate the higher expenditure of the new metering infrastructure. But to extract these benefits, discoms also need a new operational and regulatory environment as well as human resources training and capacity building (see Table 6).

It should be noted that smart meters and smart grids cannot be a panacea for the problems of discoms. Deeper structural and managerial issues cannot be solved solely through technological solutions. Also, smart meters may not be suitable for all environmentsit may be difficult to justify smart meters for few consumers or in areas where billing efficiencies are already high. The case for smart meters is easier to make in areas where the billing efficiency is low, or in the case of high-tension consumers (where time-of-day (ToD) tariff can make a significant difference).

Table 6: Summary of AMI

\begin{tabular}{|c|c|c|c|}
\hline Solution Option & $\begin{array}{c}\text { Technical Issues } \\
\text { Addressed }\end{array}$ & $\begin{array}{c}\text { Business Issues } \\
\text { Addressed }\end{array}$ & $\begin{array}{l}\text { Managerial } \\
\text { Issues } \\
\text { Addressed }\end{array}$ \\
\hline $\begin{array}{l}\text { Advanced } \\
\text { metering } \\
\text { infrastructure and } \\
\text { billing }\end{array}$ & $\begin{array}{l}\text { Peak demand } \\
\text { management } \\
\text { - Load forecasting } \\
\text { Network management } \\
\text { and data transparency }\end{array}$ & $\begin{array}{l}\text { Provisional billing } \\
\text { - Inefficient billing } \\
\text { and collection }\end{array}$ & $\begin{array}{l}\text { - Anti-theft } \\
\text { enforcement } \\
\text { - Performance } \\
\text {-linked } \\
\text { incentives }\end{array}$ \\
\hline
\end{tabular}

ix $\mathrm{AMI}$ is an integrated system of smart meters, communications networks, and data management systems that enables two-way communication between utilities and customers (Source: US Department of Energy, https://www.energy.gov/sites/prod/files/2019/02/f59/Smart\%20Grid\%20System\%20Report\%20 November\%202018_1.pdf). 


\section{Benefit to Discoms}

- Increased temporal and special granularity of electricity consumption allows discoms to pinpoint areas of inefficient system operation and predict future system upgrade requirement better.

- States with smart meters have demonstrated an increase in billing efficiency of 25 percent.

- With energy consumption data being collected at a 15-minute interval-compared to a month or two with manual meters-the discom can make use of ToD electricity tariffs that send price signals to the customer to shift their consumption to periods of lower cost.

- Having real-time information of energy consumption and flow across the network gives discoms very valuable information to aid in system planning for load growth.

\section{How to make it work?}

- Discoms: Develop a clear understanding and articulation of smart grid technology applicability considering geography, consumer mix and net value to the discom concerned.

- National Smart Grid Mission: Develop a common and scalable architecture for discoms to deploy smart meters, collect and use data, and optimise operations around improved data transparency.

- Gol: Support discoms in availing funding support for smart meter rollout, provide capacity building, create customer awareness around the benefits of smart meters and AMR meters.

\subsection{IMPROVING COLLECTION EFFICIENCY}

Even though the unauthorised use of electricity is a cognisable offence under EA2003, the theft of electricity continues to be rampant in many parts of the country. ${ }^{89}$ Discoms require the support of government machinery, in the form of police and courts, to settle legal and administrative disputes. In states such as Maharashtra, Odisha, and Manipur, such support from the government resulted in a drastic decrease in loss due to pilferage.

In Haryana, the officers of Dakshin Haryana Bijli Vitran Nigam sanctioned cash rewards to people providing information on electricity theft, pilferage of material, and corruption. ${ }^{90}$ In Gujarat, thefts have been reduced by conducting frequent crackdowns, and by setting up special police stations and courts to deal exclusively with power theft. ${ }^{91}$

Some states have also implemented prepaid metering coupled with tamper-proof techniques to tackle illegal connections. The basic premise of prepaid metering is to eliminate issues around theft, non-payment, billing, collection, and discrepancies in meter reading while at the same time improving access to customers. It also reduces the working capital requirements of discoms.

A good example of this is Manipur. The government first tested prepaid metering in parts of the capital city, Imphal, in 2011. As installation, replacement, and customer service can be done more easily in urban areas than in rural or challenging terrains, post-paid and single-point metering were continued in the hilly and rural parts of the state. Prepaid metering was supplemented with the use of tamper-proof techniques such as aerial bunched cables and sealed meters to curb illegal tapping of wires and improve the power supply (from 6-8 hours to 16-20 hours). Improved supply also encouraged consumers to pay. Monthly revenues from electricity sales increased from ₹ 5.5 crore to ₹ 10.5 crore. 
This also resulted in an overall fall in AT\&C losses by over 50 percent (see exhibit 10). ${ }^{92}$ Exhibit 10:AT\&C losses in Manipur and impact of prepaid meters (Source, PFC)

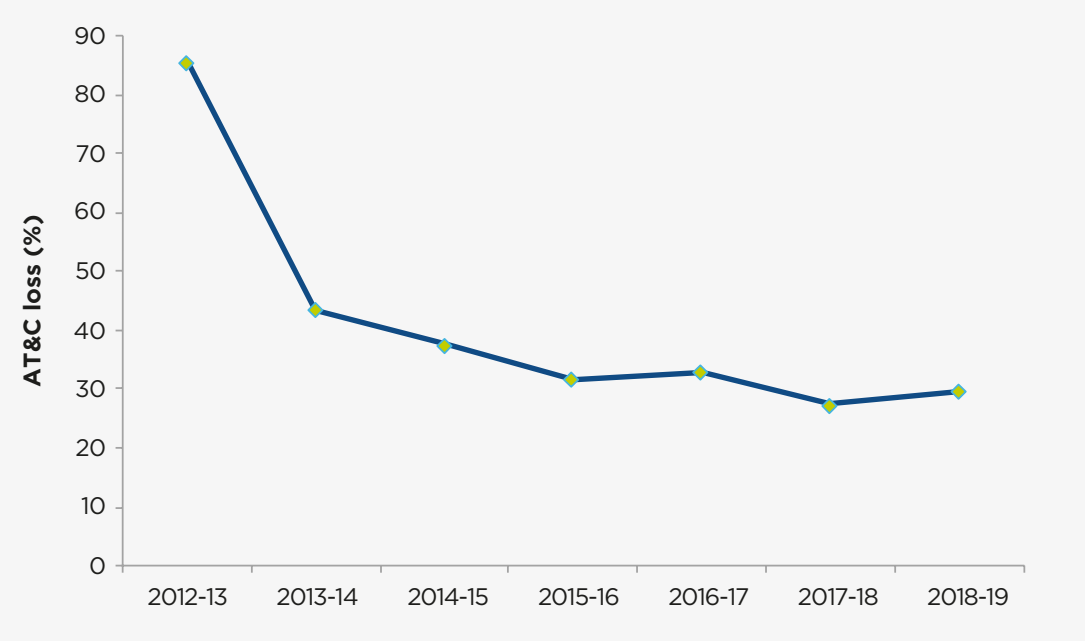

Improving collection efficiency also requires many state government departments to clear their past dues to discoms. ${ }^{93}$

\subsection{DEMAND-SIDE FLEXIBILITY AND THE ROLE OF DYNAMIC TARIFF}

The use of AMI goes beyond billing, collection and distribution automation. The granular and almost real-time data from AMI can be combined with controllable devices and dynamic tariff to increase demand flexibility. This can cater to not just load management and energy efficiency requirements, but also help in reducing peaking power needs and better management of renewables and distributed energy assets. As consumption grows, particularly with rising industrial and cooling needs, the scope for demand flexibility expands over time.

So far, in India, automated demand response (ADR) pilots have been conducted by Tata Power in Delhi and Mumbai, focusing on a limited number of commercial and industrial customers. ${ }^{94}$ If the share of renewable energy is low, then demand flexibility can also be achieved using simple heuristics to shift elastic loads. For instance, in Karnataka, the utility BESCOM decided to energise irrigation pump sets during daytime in a manner that broadly tracks solar generation patterns. This enables them to serve the morning and evening peak loads better. ${ }^{95}$

Demand flexibility can also be achieved through behavioural approaches. Behavioural Energy Efficiency (BEE) programmes work under the principle that consumers can reduce or shift their usage to flatten the load curve when supplied with relevant, eyecatching, and actionable information about their use patterns. ${ }^{96}$ BEE projects are being piloted by Jaipur Vidyut Vitran Nigam Limited (JVVNL) and BSES (see Box 6 for BSES' ongoing pilot in Delhi). 


\section{Box 6: BSES Home Energy Report Pilot ${ }^{97}$}

Distribution utilities are looking at employing demand-side measures (DSM) as a cost-effective response to rising electricity demand. Internationally, distribution utilities have been able to achieve 1-3\% energy savings per household by sending them home energy reports (HERs) which were compiled using data analytics and behavioural science.

BSES Rajdhani Power Limited (BRPL) is implementing such a BEE pilot programme in South and West Delhi. This project aims to induce residential energy savings by promoting domestic energy literacy and encouraging participation in DSM programmes. It uses a customer engagement software to study residential energy consumption habits and accordingly provides customised insights in the form of HERs. The ongoing pilot has at least 2,00,000 enrolled customers and will enable comparison between household energy use patterns using a randomised controlled trial to inform decisions about system expansion/upgrades.

ToD tariffs and real-time pricing (RTP) are electricity tariffs that change with time to reflect system conditions and provide customers a price signal that reflects the current conditions. The time-varying price signals can provide economic incentives to customers to increase or decrease energy consumption at a given time. This gives discoms another tool to lower the cost to procure and distribute electricity to their customers. Demand flexibility and dynamic tariffs hold significant benefits for discoms. But they require closer coordination between the state and the SERC coupled with support from the central government nodal agencies for their successful deployment (see Table 7).

Table 7: Summary of Demand-side Flexibility

\begin{tabular}{|c|c|c|c|}
\hline Solution Option & Technical Issues Addressed & $\begin{array}{l}\text { Business Issues } \\
\text { Addressed }\end{array}$ & $\begin{array}{l}\text { Managerial } \\
\text { Issues } \\
\text { Addressed }\end{array}$ \\
\hline $\begin{array}{l}\text { Demand-side } \\
\text { flexibility and } \\
\text { dynamic tariff }\end{array}$ & $\begin{array}{l}\text { - Local and system peak } \\
\text { management } \\
\text { - Load predictability } \\
\text { - System ramping }\end{array}$ & $\begin{array}{l}\text { - Revenue } \\
\text { realisation } \\
\text { - Customer } \\
\text { engagement and } \\
\text { choice }\end{array}$ & \\
\hline
\end{tabular}

Benefits to Discoms

- Demand-side flexibility helps in lowering the average cost of supply.

- Dynamic tariff encourages movement towards cost-reflective tariff, thereby improving revenue.

\section{How to make it work?}

- State Government and SERCs: Empower discoms to develop more granular and costreflective tariffs that are approved in a timely manner and revisited frequently.

- MoP: Develop a common 'plug and play' education and awareness campaign for discoms to educate customers on financial benefits of the programmes and increase participation. 
- Discoms: Implementation of a robust communication network and data processing approach that allow discoms to understand where flexibility exists and provide the correct price signal to the right customer at the right time.

- Discoms: Smart meter rollout with high temporal granularity to enable effective ToD programmes.

\subsection{UPGRADING DISTRIBUTION INFRASTRUCTURE}

Many loss-making discoms are unable to invest in the upgradation and maintenance of their equipment due to lack of resources. Old and dilapidated conductors, poorlysized transformers and low-quality equipment can lead to high technical losses as well as unreliable power. For instance, a recent study found that 70 percent of household customers reported one or more power cuts in the past week, and 75 percent of them had no prior notification of upcoming power cuts. ${ }^{98}$ This is a vicious cycle, since poor grid quality leads to low revenue realisation.

These losses can be brought down in many ways. When new cables are installed in periurban areas, they can be laid underground to reduce thefts and increase reliability. HT or LT aerial bunched cables ( $A B C$ ) can be used to avoid theft through direct hooking, and to reduce fault rates as well. The load profile of transformers can be studied and modified as per the connected load. This will reduce losses of the transformers and improve the voltage profile.

Some states have systematically brought down technical losses through better equipment and by instituting proper maintenance practices. Gujarat was able to reduce technical losses through steps such as the use of HT lines, prepaid/smart meters in government establishments, installation of new substations and specially designed transformers, AMR for feeders, and optimal sizing of conductors and transformers. ${ }^{99}$

Similarly, in Delhi, the AT\&C losses in Tata Power-DDL areas have shown a major decline, from 53 percent in July 2002 to 7.79 percent in April 2020. This reduction in losses was

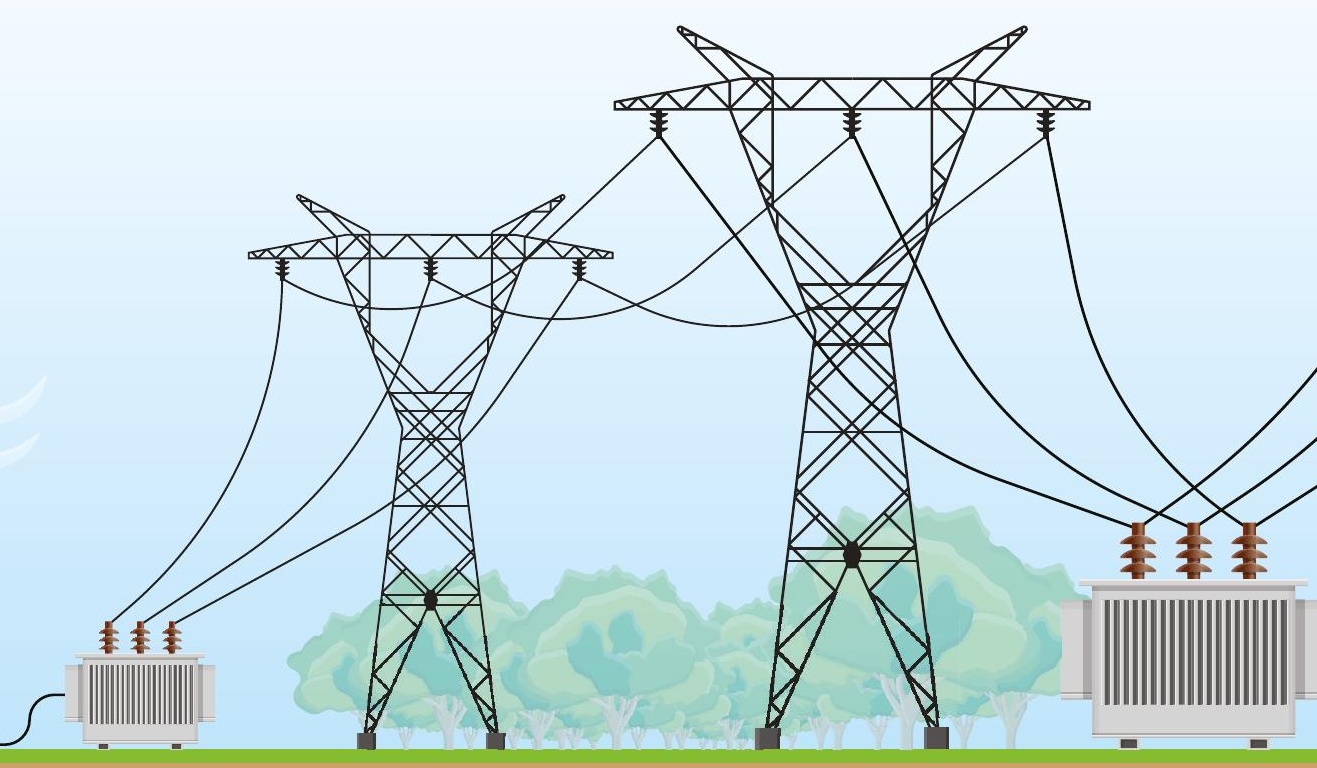


achieved by the implementation of several technologies, including Advanced Distribution Management System (ADMS), Integrated Geographical Information Systems (GIS), AMI, ADR, field force automation, and upgradation of the network. The technical losses were brought down by balancing loads, enforcing technical specifications, and replacing old and inefficient cables, panels, and transformers with high quality equipment. All this requires high capital expenditure.

\subsection{AGRICULTURAL DEMAND MANAGEMENT}

Current pilots on demand flexibility are primarily being driven in urban and industrial regions. But agricultural load management is equally important, given that most discoms have to cater to a large share of not optimised and highly subsidised agricultural demand.

States with a large rural or agricultural consumer base-such as Rajasthan, Andhra Pradesh, Gujarat, Karnataka and Maharashtra-have resorted to separating feeders for agricultural use from non-agricultural use. This measure has been adopted to regulate agricultural consumption and manage peak loads. Investment in feeder separation has been encouraged by the Centre through the DDUGJY.

Solar pump deployment has also received a push through the Pradhan Mantri Kisan Urja Suraksha evam Utthan Mahabhiyan (PM-KUSUM) scheme. This scheme is meant to support installation of off-grid solar pumps in areas with poor grid supply, and reduce the dependence on grid power in grid-connected areas. The scheme will help farmers set up standalone solar pumps, and solarise their grid-connected pumps. Farmers can set up solar power generation capacity on fallow and barren lands and sell the power to discoms. ${ }^{100}$ Faster implementation of this scheme requires cooperation among the Centre, states, and other stakeholders (including farmers, manufacturers, and integrators). ${ }^{101}$

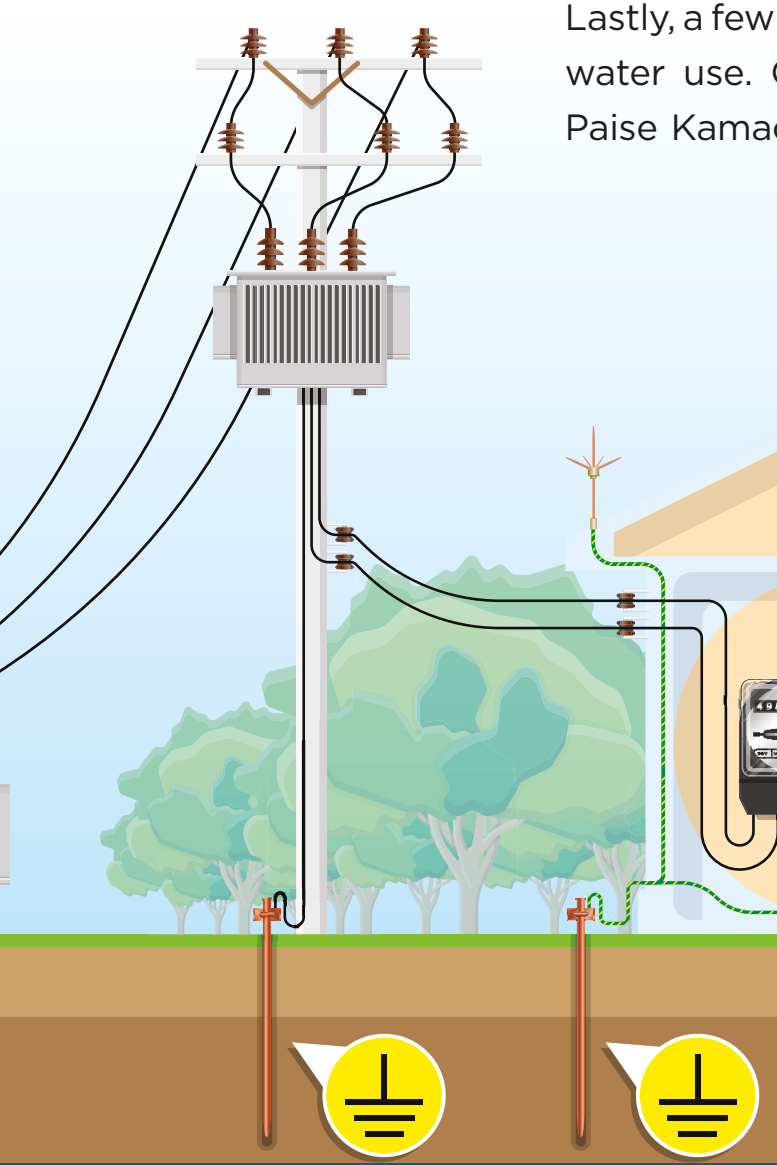

Lastly, a few states are looking at energy efficiency measures to optimise water use. One such pilot is the previously discussed Paani Bachao Paise Kamao scheme (see Box 4). 


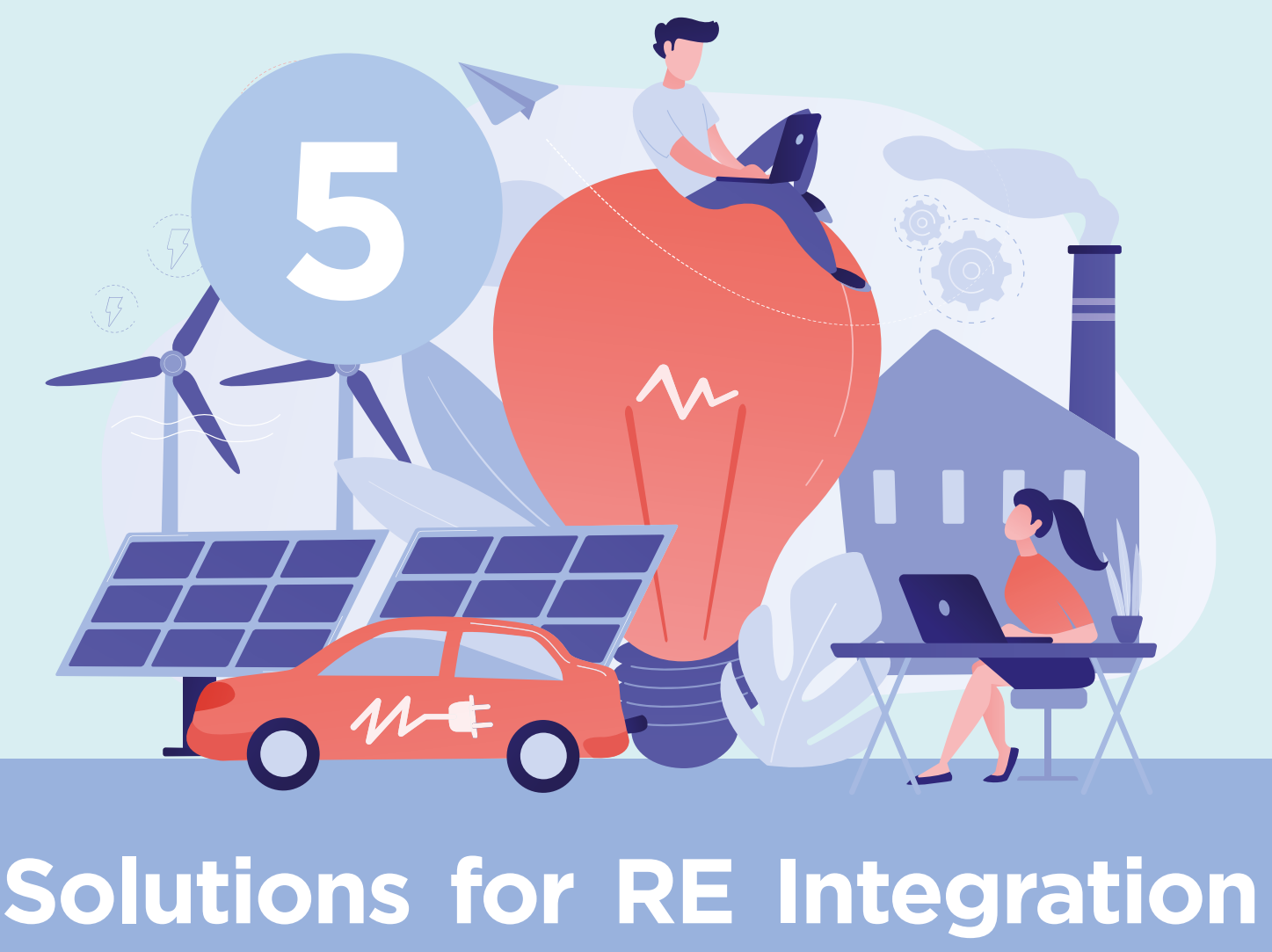

India has set the ambitious target of generating $450 \mathrm{GW}$ of solar and wind power by 2030. If this target is met, renewable energy would account for more than 50 percent of the power generation capacity and more than a quarter of all the electricity produced.

However, the challenge of RE integration and curtailment must be resolved. RE can impose additional costs on the system, and it is important to determine the corresponding full system cost. ${ }^{102}$ If not managed well, greater penetration of RE can impact the technical and financial functioning of discoms. ${ }^{103}$

As discussed earlier, contractual inflexibility aside, growth in renewables has compounded the problems of power procurement for discoms. While progress has been made in the regional integration of RE at the transmission end, gaps have remained in the discoms' preparedness with respect to avoidance of curtailment and management of existing long-term PPAs.

As the primary offtaker of RE and given the concentrated generation and localised consumption, discoms remain critical in RE integration. However, there are many potential sources of flexibility in renewables-rich states. These include demand-side flexibility, longterm supply and demand analysis and integrated resource planning (IRP), RE forecasting and scheduling (including weather and load), identification of flexible balancing resource beyond thermal generation, optimal use of power exchanges, and managing growth in RTS and other DER assets. ${ }^{104}$

\subsection{REGIONAL INTERCONNECTION AND BALANCING}

Power system operators and load dispatch centres balance electricity supply and demand within specified areas, called balancing areas, which include a fixed portfolio of generators. 
These areas are often associated with state boundaries and have physical and political constraints as well as contractual considerations. Discoms often 'self-schedule' generators with which they have PPAs. Power that is not procured through the self-scheduled bilateral contracts is acquired in the wholesale market. This makes up less than 10 percent of the power procured by discoms.

As the peakier demand curve across the country and the intermittency of RE power generation cross paths, it can lead to a significant supply-demand mismatch. Hence, increasing coordination and trading between balancing areas will increase the efficiency of energy flow across the network, improve economic efficiency of power procurement, and enable better integration of variable renewable generators.

The Green Energy Corridor is a central government scheme, amounting to ₹ 43,000 crore, focusing on transmission augmentation to facilitate the evacuation of RE into the national grid. ${ }^{105},{ }^{106}$ This ties in with the setting up of renewable energy management centres (REMCS) which are equipped with advanced RE forecasting and visualisation tools to help grid operators. To aid all this, power market reforms, such as RTM, and trading mechanisms, such as RECs, have been introduced. Regional interconnections can address multiple technical and managerial issues faced by discoms, but their success hinges on the close coordination between multiple central and state government nodal agencies with the discoms (see Table 8).

Table 8: Summary of regional interconnection and balancing

\begin{tabular}{|c|c|c|c|}
\hline Solution Option & $\begin{array}{l}\text { Technical Issues } \\
\text { Addressed }\end{array}$ & & \\
\hline $\begin{array}{l}\text { Regional } \\
\text { interconnection } \\
\text { and balancing }\end{array}$ & - T\&D congestion & $\begin{array}{l}\text { - High APPC } \\
\text { - Uneconomic dispatch }\end{array}$ & $\begin{array}{l}\text { - Near and long- } \\
\text { term planning }\end{array}$ \\
\hline \multicolumn{4}{|c|}{ Benefits to Discoms } \\
\hline \multicolumn{4}{|c|}{$\begin{array}{l}\text { Price discovery: Dispatching power on short-term / near real-time intervals improves } \\
\text { utilisation of generation assets and allows for better integration of zero marginal costs } \\
\text { generators by using short-run marginal production cost for the merit order dispatch. } \\
\text { - Increased transparency and competition: Market transparency and short-term power trading } \\
\text { enable discoms to accurately balance supply and demand at short time intervals while also } \\
\text { allowing them to sell surplus power that has fixed costs in existing contracts. }\end{array}$} \\
\hline \multicolumn{4}{|c|}{ How to make it work? } \\
\hline \multicolumn{4}{|c|}{$\begin{array}{l}\text { - CERC: Enable more interstate trading by amending rules that require } 15 \text {-minute firm trading } \\
\text { blocks to allow for greater participation of VRE. } \\
\text { - Gol: Invest in adequate interstate transmission capacity to meet future need in high RE } \\
\text { penetration regions. } \\
\text { - SLDCs, REMC, RLDCs, Discoms: Share best practices across regional load dispatch centres } \\
\text { and increase coordination. } \\
\text { - Discoms and Gencos: Increase liquidity on the power exchanges by moving more procurement } \\
\text { to the wholesale market and continue to shift away from heavy reliance on long-term PPAs. } \\
\text { - Improved intrastate trading with balancing areas larger than state level will require regulatory } \\
\text { (state) and management changes that are currently constrained to state level only. }\end{array}$} \\
\hline
\end{tabular}




\subsection{RENEWABLE PURCHASE OBLIGATIONS}

RPOs are a policy instrument to ensure the uptake of renewable energy. They require discoms, energy producers and certain consumers to obtain a share of their electricity from renewable sources. ${ }^{x}$

Renewable deployment remains highly concentrated in a few resource-rich states. The top six states account for 78 percent of all the RE generated. ${ }^{107}$ The must-run status of RE means that some states end up purchasing more than what they are required to while others do not even meet their RPOs. Enabling greater inter-regional transfer of RE can help reduce the financial burden on discoms. ${ }^{108}$ This can be done through the physical transfer of power through grid interconnections, as discussed in previous section, or through the mechanism of tradable renewable energy certificates. ${ }^{\text {i }}$

Despite tradeble RECs and grid interconnections helping less resource-rich states procure RE and meet their RPOs, RE consumption continues to be localised. In 2019-20, only four states-already rich in RE generation-achieved or exceeded their RPO target: Karnataka, Andhra Pradesh, Rajasthan and Tamil Nadu. ${ }^{109}$ A stringent implementation of the RPO mandate would ensure a fairer distribution of the excess cost of absorbing RE. ${ }^{110}$

\subsection{ADVANCED RE FORECASTING}

Variable renewable generation is inherently uncertain. It requires grid operators to undertake measures to balance supply and demand when generators over- or underproduce as compared to the expected or contracted amount. Increasing the accuracy of RE generation forecasts lowers the need for real-time system balancing and the fees associated with the Deviation Settlement Mechanism (DSM) penalty imposed on discoms. More accurate RE forecasts also improve grid reliability and stability while allowing for a more cost-optimum economic dispatch of other generators in the fleet (see Table 9).

Many RE-rich countries have already identified the need for more accurate forecasting. Lessons from the experiences of such countries can help us prepare for RE integration challenges (see Box 7 for case study).

$x$ In June 2018, the RPO requirement was raised from $17 \%$ to $22 \%$, with $10.5 \%$ from solar, up from $6.75 \%$, and $10.5 \%$ from non-solar renewable sources by 2022 , up from $10.25 \%$. This increase has been in line with the government's ambition to deploy $450 \mathrm{GW}$ of renewables by 2030.

xi RECs are tradable certificates used by generators and other entities to sell RE generation on the power exchange for other obligated entities to meet their RPO requirements without having to deal with actual power procurement. 


\section{Box 7: International experience in RE forecasting ${ }^{111}$}

The German power sector hosts more than $75 \mathrm{GW}$ of solar and wind power today. Germany has bestowed a 'must-run' status upon renewables, like India. But unlike in India, where RE power producers are expected to submit $\mathrm{RE}$ forecasts and are penalised for deviation in forecasts, in Germany the Transmission System Operators (TSOs) manage RE forecasting activities, relieving the power producers from submitting their individual forecasts.

The TSOs have built expertise in forecasting by leveraging meteorologists. They are capable of evaluating various forecasts and deploying post-processing schemes based on different forecast service providers. TSOs leverage several $\mathrm{RE}$ forecasts from different providers to increase knowledge about forecast uncertainty.

A similar model is witnessed in Australia where the Australian Energy Market Operator (AEMO) runs the state-of-the-art Anemos platform, one of the best power prediction systems for renewable energy. The prediction platform allows the incorporation of several RE forecast models from various providers.

Table 9: Summary of advanced RE planning and forecasting

\begin{tabular}{|l|l|l|l|}
\hline \multicolumn{1}{|c|}{ Solution Option } & \multicolumn{1}{|c|}{$\begin{array}{c}\text { Technical Issues } \\
\text { Addressed }\end{array}$} & $\begin{array}{c}\text { Business Issues } \\
\text { Addressed }\end{array}$ & $\begin{array}{c}\text { Managerial Issues } \\
\text { Addressed }\end{array}$ \\
\hline $\begin{array}{l}\text { Advanced RE } \\
\text { planning and } \\
\text { forecasting }\end{array}$ & $\begin{array}{l}\text { Adre curtailment } \\
\text { - System congestion }\end{array}$ & - High APPC & - $\begin{array}{l}\text { Near and long-term } \\
\text { planning }\end{array}$ \\
\hline & - Grid outages & & $\begin{array}{l}\text { RE purchase } \\
\text { obligation }\end{array}$ \\
\hline
\end{tabular}

\section{Benefits to Discoms}

- Power Procurement Cost: As RE generators are deemed with a 'must-run' status, inaccurate forecasting of RE generation can disturb the merit order dispatch of power plants for the discom which can increase the overall cost of power procured.

- DSM Penalty: Inaccurate forecasts in RE generation can lead to an over or underestimation of the actual power generated. If RE generation is lower than forecasted, discoms are forced to overdraw from generators inducing a DSM penalty.

- Grid Disturbances and Outages: Large errors in RE forecasting can lead to real-time mismatch between power supply and demand and force discoms to induce grid outages.

\section{How to make it work?}

- Discoms: Develop an approach to increase the visibility of distributed PV and create a methodology for including behind-the-meter RTS into discoms and LDCs operation plans.

- SERCs and Discoms: Introduce Artificial Intelligence based advanced weather forecasting tools to improve the accuracy of day-ahead and real-time renewable energy production. 


\subsection{DECENTRALISED RENEWABLE ENERGY}

There is a renewed interest in decentralised renewable energy (DRE) systems today due to the sharp fall in prices (especially of solar photo-voltaic), the imperative of decarbonisation, the continuing shortage or unreliability of electricity in many parts of the country, and the desire for greater resilience. DERs such as RTS plants and mini-grids offer opportunities to both discoms and consumers, but there are several unresolved issues holding back greater deployment.

\subsubsection{Rooftop Solar}

RTS power is a clean source of energy that lets producers monetise an otherwise idle asset, their rooftops. As most of the energy produced is consumed on the same premises, the loss associated with this source is very small. However, India is lagging in achieving its RTS goal of $40 \mathrm{GW}$ installation by 2022-till June 2020, only 15 percent (or $6 \mathrm{GW}$ ) had been attained.

The state-level performances vary based on the policy and regulatory frameworks and support, business and investment environment, as well as consumer experience. MNRE's State Rooftop Solar Attractiveness Index (SARAL) measured states' performance across these broad buckets and ranked Karnataka as the best state for RTS. At the same time, it also highlighted administrative inconsistencies, inadequate financing, complexity of institutional frameworks, etc., as hurdles in greater adoption. ${ }^{112}$ DER can also pose other challenges for stakeholders such as discoms. These include:

- Discoms perceive the rising RTS adoption/captive generation and use of OA market among C\&l customers as unfavourable since they form the bulk of their revenue stream.

" Further, discoms prefer gross metering over net metering ${ }^{\text {xii }}$ for smaller consumers since the tariff differential in gross metering could potentially mitigate some of their lost revenue.

" Even with policy changes that enable integration of mini and micro grids into the central grid, discoms will still need to set up the required interconnections as well as pay the necessary feed-in-tariffs ${ }^{\text {xiii }}$ to mini-grid developers. ${ }^{113},{ }^{114}$ Introduction of variable renewable energy to the grid may also require discoms to deal with congestion/accommodate surplus electricity on the grid during low demand. This can lead to curtailment of solar/RE projects violating the 'must-run' clause they carry. This can discourage existing and potential solar/ RE developers.

Discoms need to encourage the adoption of RTS generation across all consumer segments for India to meet its ambitious RE goals by 2022. There is a need for discoms to draft

xii In gross metering, the consumer is paid a fixed rate (the feed-in-tariff, FIT) for the total number of units of solar energy he generates and exports to the grid. The consumer continues to pay the discom at the retail supply tariff for the electricity he consumes from the grid. In net metering, the consumer's electricity exports are adjusted against his imports - effectively, the consumer is paid at the retail supply tariff.

xiii Feed-in tariffs are a policy mechanism under which renewable energy producers receive a long-term assurance of power purchase at guaranteed prices. 
long-term integrated resource plans that identify specific deployment goals for RTS that can benefit with T\&D loss reduction, peak-load management and power-procurement optimisation.

\subsubsection{Minigrids}

While the country has nearly achieved universal electrification, the quality of power supplied in many parts of the country is far from being reliable or consistent. ${ }^{115}$ Minigrids are a collection of DERs that can supplement the existing electricity distribution network or act as standalone electricity generation and distribution systems in off-grid and sparsely populated areas. For this reason, mini-grids are seen as sustainable and potentially cost-effective, which can help advance electricity access in areas where the cost of expanding the grid exceeds the revenue potential for discoms, such as in remote rural areas. Mini and micro-grids, by virtue of being located close to the community to be served, can minimise T\&D losses, thereby improving the quality of service and in effect, increasing the willingness to pay for the service. Improving access can also stimulate economic activity and positively impact development.

There are over 14,000 micro and mini-grids and over 20 lakh solar home systems operating in India.116 Given the quality of rural energy access, it is estimated that in Bihar alone around 28 lakh households could be served by 11,200 mini grids'17 (see Box 8 for case study).

\section{Box 8: Bihar's mini-grid story - an alternate way to provide electricity in rural India'18,119,120,121,122,123}

Although India achieved 100\% household electrification in 2019, 37 percent of the rural households in Bihar lack access to reliable electricity. Mini-grids are seen as dependable alternative sources of power in the state, with over 8 percent of the nation's mini-grids found in Bihar. The state's policy aims to build on this momentum and install a further $100 \mathrm{MW}$ of sub $500 \mathrm{~kW}$ renewable-based minigrids. Private energy service companies (ESCOs), such as Husk Power, have been leading the way in the state.

Husk Power relies on establishing a base demand through anchor loads such as agricultural facilities, telecom towers, or similar industrial users, which improve the utilisation rate for the mini-grid, reducing the average cost of supply.

Tariffs set by Husk Power are cost-reflective and offer no subsidies, allowing for tariff setting at the mutual discretion of the developer and consumers. Despite higher tariffs as compared to centralised grids (which are now available where mini-grids operate), most customers are happy to pay the premium for a reliable supply of electricity.

For example, Husk Power's 32kW biomass-solar hybrid plant near Piprakothi in Bihar, continues to serve 250 customers despite grid extensions in the area. Hence, despite fears that insufficient regulations and uncertainty about grid arrival might deter investment, Husk Power managed to raise ₹2 crore in 2018. 
To prevent mini-grids from becoming stranded assets due to the expansion of the centralised grid, the state policy has laid out a number of options for developers, including continued operation in parallel with the grid, selling power to the discom at a regulator-determined feed-in tariff, transferring ownership of assets and network to the discom and engaging with the discom as a distribution franchisee.

Husk Power's success is also attributed to its use of smart technology, such as remote monitoring of mini- grids and mobile-enabled smart prepaid meters with a 'pay-as-you-go' system suited for customers with irregular income streams.

Husk Power's story in Bihar reinforces the consumers' willingness to pay greater tariffs for electricity that is more reliable. It also reinforces the importance of support from the government via relevant reforms and policies.

\subsubsection{Energy Storage and Aggregated DERs}

Energy storage is increasingly in the spotlight as a big opportunity for grid modernisation. Storage can play a major role in firming up the grid and enabling high penetrations of renewable generation. Batteries and pumped hydro-storage systems are already being used in various places across the world while other storage technologies, such as flywheels, supercapacitors, and green hydrogen, are in the early stages of development.

Pumped hydro-storage plants involve storing excess power by using it to pump water into a reservoir at a height. When required, the water can be released through a turbine to generate electricity. This is a proven and efficient way to store energy. It can also provide ancillary services such as frequency and voltage regulation, and black start facility.

Batteries represent a wide range of technologies that can provide numerous benefits to the grid. Importantly, a single battery can provide several services over its life. For example, a battery system can be installed for the primary purpose of shifting peak electricity consumption from a time when the distribution or transmission is congested to a time when capacity is available. This may only require the battery to be dedicated to this service for a few hours each day. When that battery is not providing this peak shifting service, it can be used as a firming or flexibility resource to smoothen renewable generation to better match demand.

The CEA has run a modelling exercise to estimate the generation capacity mix in 2030 . The model suggests a likely installed capacity of over $10 \mathrm{GW}$ of pumped storage and 27 GW of four-hour battery storage. ${ }^{124}$

Several pilots on energy storage have been in the works across the country:

" In Delhi, TPDDL has installed a $10 \mathrm{MWh}$ battery bank commissioned by AES and Mitsubishi in 2019 at the substation level. ${ }^{125}$ The battery bank is capable of applications ranging from peak load management, frequency regulation to system flexibility. It helps balance distributed energy resources including RTS. 
- A 1.25 MW battery storage pilot was also commissioned in Puducherry in 2017 for PGCIL with the objective of testing the technical and economic effectiveness of grid-connected battery energy storage systems in providing dynamic frequency regulation, capacity firming, energy time shift of renewable energy generators, peak shaving and load following, dynamic reactive compensation and voltage support. ${ }^{126}$

" Also in Delhi, BRPL is planning to deploy a $10 \mathrm{MW}$ BESS for managing the distribution network congestion and for reducing peak power purchase requirements along with other incidental benefits to the distribution system ${ }^{127}$.

Aggregating distributed energy resources (DERs) across a network and controlling the collective operation of the fleet allows the network of decentralised resources to provide a similar set of grid services as a traditional centralised generator or energy storage system. The objective of aggregated DER is to optimise the interconnected assets through a central control room while allowing the ownership of those assets to remain independent of the discom. A central control room or DER system operator dispatches the aggregated resources to adjust to balancing needs of the grid in the same way a centralised generator does (see Table 10).

Table 10: Summary of energy storage and aggregated DERS

\begin{tabular}{|c|c|c|c|}
\hline Solution Option & Technical Issues Addressed & $\begin{array}{l}\text { Business Issues } \\
\text { Addressed }\end{array}$ & $\begin{array}{l}\text { Managerial } \\
\text { Issues } \\
\text { Addressed }\end{array}$ \\
\hline $\begin{array}{l}\text { Energy storage, } \\
\text { aggregated } \\
\text { DERs, and virtual } \\
\text { power lines }\end{array}$ & $\begin{array}{l}\text { - System reliability } \\
\text { - } \text { RE curtailment } \\
\text { - Resilience to weather } \\
\text { events }\end{array}$ & $\begin{array}{l}\text { High APPC } \\
\text { Competition from } \\
\text { DERs and open } \\
\text { access }\end{array}$ & $\begin{array}{l}\text { RE purchase } \\
\text { obligation }\end{array}$ \\
\hline \multicolumn{4}{|c|}{ Benefits to Discoms } \\
\hline $\begin{array}{l}\text { - Provides inexp } \\
\text { - Allows for incre }\end{array}$ & $\begin{array}{l}\text { ive balancing reserves. } \\
\text { ed demand and supply-side }\end{array}$ & ibility. & \\
\hline
\end{tabular}

\section{How to make it work?}

- CERC: Develop ancillary service market that includes participation of large DERs and aggregated small and medium DERs.

- Discoms: Accelerate smart meter infrastructure rollout and ensure bi-directional communication networks are adopted.

- CERC and State Government: Develop performance-based regulation that encourages accurate DER generation forecasts and load management. 


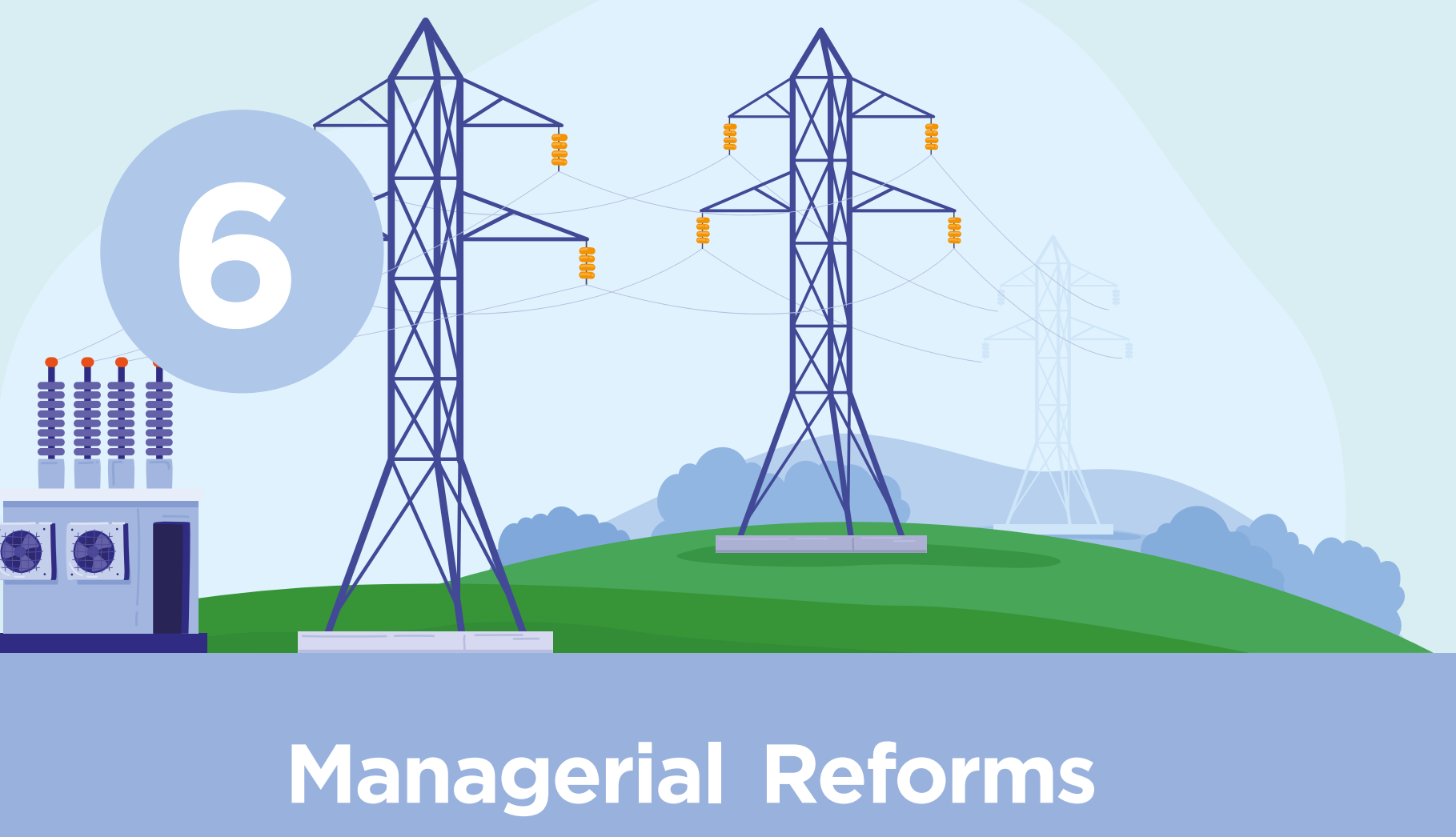

\subsection{VISION AND LEADERSHIP}

Discoms are service providers that follow standard operating procedures like most enterprises. The majority of discoms are publicly owned. As noted above, some of them have tremendously improved by implementing operational and managerial reforms.

Bold leadership from government institutions, private enterprises, civil servants and elected officials has significantly reformed the electricity sector. Effective reforms are typically a result of stable leadership and vision sustained over time. Good leadership endures shifts in political leanings, navigates technological hype cycles, and holds the line over time to deliver its vision through persistence and dedication to transformation.

Reform journeys in Gujarat, Delhi and Andhra Pradesh were led by elected officials who retained their position in power for at least a decade. These officials were successful because they drafted long-term strategies with regulators and discoms and could ensure the rollout of policies and implementation of reforms. TPDDL, for example, had a distribution license for 25 years that allowed it to prepare long-term strategies that resulted in steady and incremental improvement. ${ }^{128}$

Transformation is enabled by innovation, and decision-makers across the ecosystem must be open to new ideas and processes, and ways of doing business. This, however, is contingent on the acceptance and integration of such innovation into the organisation. This applies to the use of technology upgrades for organisational improvements, implementing management information systems (MIS) and performance review systems, as well as for improving billing and collection, and consumer interfaces. 


\subsection{CUSTOMER FACILITATION}

Many states have tried to improve their customer-facing processes. Maharashtra, for example, set up a centralised call centre. Gujarat initiated online bill payment facility, SMS service, and Jan Seva Kendra for its consumers, with a view to reduce AT\&C losses. ${ }^{29}$ Delhi, Odisha, and Andhra Pradesh successfully deployed technology to improve their overall customer experience.

Customers today can be more engaged in how they interact with the grid. Discoms can benefit greatly from this opportunity by rolling out proactive initiatives such as ToD tariffs, which could benefit both discoms and customers. If discoms do not capitalise on this opportunity, customers might choose to defect from discoms towards self-generation or OA.

\subsection{EMPLOYEE INCENTIVES AND WORKER PROTECTION}

Discom employees should be incentivised to align with the organisation's interests. This can help improve operations and financial performance. The incentive need not be limited to remuneration. Job security, cultural buy-in, and healthy competition among the employees can improve the discom's performance.

For instance, Tata Power-DDL made managers responsible for the costs and revenues in their areas and provided incentives on the basis of their performance. Distributed leadership was implemented to run the setup as individual business units with adequate manpower. A three-tier performance management system was conceived for encouraging competition and organisational alignment among the employees. ${ }^{94}$ In Manipur, structural and role accountability were established via periodic reviews at the field level. In Gujarat, the discoms introduced a performance-incentive scheme, where utilities pay an additional 4 percent of wages to incentivise and encourage workers to outperform targets. ${ }^{130}$

As mentioned in the section above, job security can be a powerful incentive in improving employee performance. It can be especially salient in the case of privatisation of discoms, where concerns among the employees about job loss could adversely impact performance.

Section 133(2) of the Electricity Act, 2003, states that the service conditions of employees would not be in any way inferior to those that were there while the discom was stateowned. The case of Odisha is a good example-despite the discom changing ownership several times since the late ' 90 s, the employees were insulated from any adverse impacts. ${ }^{131}$

A contrasting example can be traced back to Uttar Pradesh, where lack of consultation and consensus with the employee unions in Kanpur forced Torrent Power to abandon operations in the city despite winning the DF bid. ${ }^{132}$ 


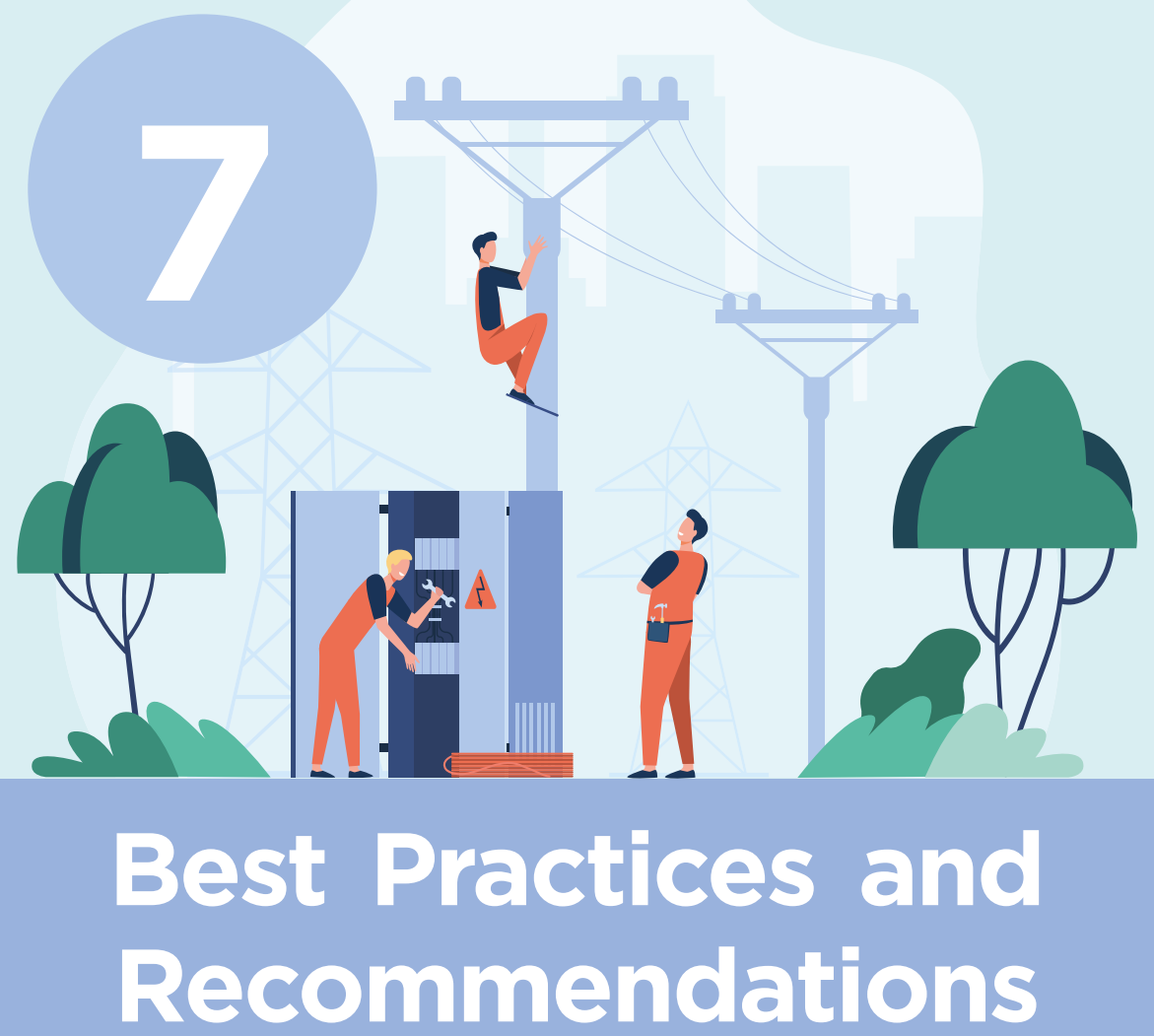

\subsection{REVIEW OF BEST PRACTICES}

Table 11 presents a summary of the experiences of selected states/utilities in their transformation efforts. These states were chosen to illustrate the crucial roles that managerial and operational reforms played in their path to loss reduction. The table also attempts to distil key common lessons that can serve as guiding principles for good operational and managerial/ management practices for discoms. 
Table 11: Selective examples of successful discom performance improvement

\begin{tabular}{|c|c|c|}
\hline States & Best Practices & Key Takeaways \\
\hline $\begin{array}{l}\text { New Delhi } \\
\text { (TPDDL) } \\
\text { private } \\
\text { licensee }^{133}\end{array}$ & $\begin{array}{l}\text { AT\&C loss trajectory } 45 \% \text { in } 2001-02 \text { to } 9.1 \% \text { in } 2018-19 \\
\text { ACS-ARR Gap (₹ /kWh): } 0.61 \text { in } 2009-10 \text { to }-0.21 \text { in } \\
2018-19 \\
\text { Initial Measures: } \\
\text { - PPP Model introduced in 1999. TPDDL \& BSES awarded } \\
\text { distribution licenses for Delhi discoms } \\
\text { - Government support in enabling transition to private } \\
\text { licensee } \\
\text { Management Reforms } \\
\text { - Dedicated Corporate Strategy Planning and } \\
\text { Performance Management Group to formulate a long- } \\
\text { term strategic plan } \\
\text { - 'Distributed Leadership' was implemented to run } \\
\text { the setup as individual business units with adequate } \\
\text { manpower } \\
\text { - Transfer of state utility employees to TPDDL with } \\
\text { benefits, and two-way communication channels } \\
\text { established for grievance redressal } \\
\text { - A three-tier performance management system } \\
\text { was conceived for encouraging competition and } \\
\text { organisational alignment among the employees } \\
\text { - A Strategic Leadership Team (SLT) maintained focus } \\
\text { on action plans and planned deliverables through } \\
\text { corrective and preventive actions } \\
\text { - Technology Measures: GIS Mapping of assets, AMR } \\
\text { meters, tamper- proof static meters, SCADA Control } \\
\text { Systems }\end{array}$ & $\begin{array}{l}\text { Management } \\
\text { reform rode on } \\
\text { strong government } \\
\text { support given to } \\
\text { licensees } \\
\text { Institution of } \\
\text { strategic planning } \\
\text { and performance } \\
\text { management } \\
\text { Job security, } \\
\text { cultural buy-in, and } \\
\text { healthy competition } \\
\text { among the } \\
\text { employees improve } \\
\text { organisation's } \\
\text { performance }\end{array}$ \\
\hline $\begin{array}{l}\text { Haryana, } \\
\text { public } \\
\text { licensees }{ }^{134}\end{array}$ & $\begin{array}{l}\text { AT\&C loss trajectory: } 27 \% \text { in } 2012-13 \text { to } 18.1 \% \text { in } 2018-19 \\
\text { ACS-ARR Gap (INR/kWh): } 0.94 \text { in } 2012-13 \text { to }-0.05 \text { in } \\
\text { 2018-19 } \\
\text { Profitability (₹ Crores): }-23,358 \text { in 2012-13 to } 281 \text { in } \\
2018-19 \\
\text { Initial Measures: } \\
\text { - Reduction in interest burden through UDAY } \\
\text { - Transition towards cost-reflective tariff via tariff hike } \\
\text { Management and Operational Measures: } \\
\text { - Leadership direction of CMD } \\
\text { - Performance-based transfer policy } \\
\text { - Regular touring and interaction with field staff } \\
\text { - Compensation Policy } \\
\text { - Reward scheme for vigilance work } \\
\text { - Theft detection and imposition of fines } \\
\text { Technology Measures: Aggressive installation of smart } \\
\text { meters leading to elimination of manual intervention in } \\
\text { meter reading }\end{array}$ & $\begin{array}{l}\text { Leadership was } \\
\text { key }{ }^{135} \\
\text { Internal focus on } \\
\text { improving staff } \\
\text { performance } \\
\text { through incentive } \\
\text { programmes }\end{array}$ \\
\hline
\end{tabular}




\begin{tabular}{|c|c|c|}
\hline States & Best Practices & Key Takeaways \\
\hline $\begin{array}{l}\text { Andhra } \\
\text { Pradesh, } \\
\text { public } \\
\text { licensees }^{136}\end{array}$ & $\begin{array}{l}\text { AT\&C loss trajectory: } 18 \% \text { in } 2007-08 \text { to } 10.55 \% \text { xiv in } \\
2014-15 \\
\text { ACS-ARR Gap (₹/kWh): } 0.94 \text { in } 2008-09 \text { to } 0.75 \text { in 2014- } \\
15 \\
\text { Initial Measures: Sustained political leadership } \\
\text { Management Measures: Focus was on deploying reforms } \\
\text { and long-term strategies to reduce power bills and } \\
\text { attract private investments in the power sector. Strong } \\
\text { collaboration among state government, regulator and } \\
\text { utilities } \\
\text { Technology Measures: HVDS System, Energy Efficient } \\
\text { Pump Programme, DTR Replacement using Vehicle } \\
\text { Tracking System, OMS applications to monitor feeder } \\
\text { interruptions, completereplacement of electro-mechanical } \\
\text { meters with high-accuracy electronic meters }\end{array}$ & $\begin{array}{l}\text { Strong leadership } \\
\text { coupled with focus } \\
\text { on reform planning } \\
\text { Deployment of } \\
\text { phased roadmap } \\
\text { with clear } \\
\text { objectives }\end{array}$ \\
\hline $\begin{array}{l}\text { Gujarat, } \\
\text { public } \\
\text { licensees }^{137}\end{array}$ & $\begin{array}{l}\text { AT\&C loss trajectory: } 18 \% \text { in } 1996-97 \text { to } 14 \% \text { in } 2018-19 \\
\text { ACS-ARR Gap (₹/kWh): } 0.04 \text { in } 2008-09 \text { to }-0.02 \text { in } \\
2018-19 \\
\text { Profitability (₹ Crores): } 149 \text { in 2008-09 to } 184 \text { in } \\
2018-19 \\
\text { Financial Measures: Fuel \& Power Purchase Price } \\
\text { Adjustment (FPPPA) model enabled marginal quarterly } \\
\text { tariff adjustment minimising gap between costs and } \\
\text { revenue } \\
\text { Institutional Measures: Distribution licenses implemented } \\
\text { in Ahmedabad, Gandhinagar and Surat, frequent theft } \\
\text { drives, setting up of special police stations and special } \\
\text { courts to deal exclusively with power theft } \\
\text { Operational Measures: Jyotigram Yojana by the state } \\
\text { government helped improve rural power supply by } \\
\text { segregating agricultural feeders, use of HT lines, prepaid/ } \\
\text { smart meters in govt establishment, installation of new } \\
\text { substations and specially-designed transformers, AMR } \\
\text { for feeders }\end{array}$ & $\begin{array}{l}\text { Feeder separation } \\
\text { and focus on } \\
\text { infrastructure } \\
\text { development } \\
\text { Anti-theft } \\
\text { programmes } \\
\text { coupled with } \\
\text { consumer-centric } \\
\text { billing and payment } \\
\text { initiatives to make } \\
\text { payment seamless }\end{array}$ \\
\hline
\end{tabular}

xiv Andhra Pradesh's performance has since reverted owing largely to increase in power purchase cost stemming from high RE growth, capacity payment for legacy PPAs, weak demand growth leading to overcapacity, and within this environment continuous encouragement of RE deployment leading to growing curtailment issues. 


\begin{tabular}{|c|c|c|}
\hline States & Best Practices & Key Takeaways \\
\hline $\begin{array}{l}\text { Manipur, } \\
\text { public } \\
\text { licensee }^{138}\end{array}$ & $\begin{array}{l}\text { AT\&C loss trajectory: } 52 \% \text { in } 2015-16 \text { to } 29.8 \% \text { in } 2018- \\
19 \\
\text { ACS-ARR Gap (₹ / kWh): } 0.50 \text { in } 2015-16 \text { to } 0.10 \text { in } \\
2018-19 \\
\text { Profitability (₹ Crores): }-45 \text { in } 2015-16 \text { to }-19 \text { in 2018-19 } \\
\text { Initial Measures: Unbundling and corporatisation } \\
\text { initiated in } 2015 \\
\text { Institutional Measures: Controlled energy theft } \\
\text { using special courts and police forces; detection and } \\
\text { disconnection of unauthorised connections and tapping; } \\
\text { Community participation to improve O\&M including theft } \\
\text { prevention } \\
\text { Management Measures: Instituting new processes and } \\
\text { mechanisms such as project review training, frameworks, } \\
\text { data flow, division-wise and MD-level dashboards for } \\
\text { monitoring project performance; establishing structural } \\
\text { and role accountability via periodic reviews at the field } \\
\text { level } \\
\text { Technology Measures: Installed prepaid meters; } \\
\text { computerised billing and revenue collection; integrated } \\
\text { feeder-wise performance monitoring systems, installing } \\
\text { aerial bunched cables for LT connections, sealed meters } \\
\text { to check tampering }\end{array}$ & $\begin{array}{l}\text { Improved power } \\
\text { availability and } \\
\text { supply through } \\
\text { improving O\&M } \\
\text { measures } \\
\text { Prepaid metering } \\
\text { was supplemented } \\
\text { with improved } \\
\text { power supply } \\
\text { resulting in } \\
\text { improved billing } \\
\text { and collection } \\
\text { efficiency as well as } \\
\text { lower commercial } \\
\text { losses }\end{array}$ \\
\hline $\begin{array}{l}\text { Odisha } \\
\text { (FEDCO, } \\
\text { private } \\
\text { distribution } \\
\text { franchisee) } \text { (139 }^{139}\end{array}$ & $\begin{array}{l}\text { AT\&C loss trajectory: Average } 23 \% \text { reduction between } \\
2013-2017 \\
\text { Initial Measures: FEDCO was given franchisee for four } \\
\text { divisions in } 2013 \text { following the challenges faced by } \\
\text { existing licensees } \\
\text { Operational Reforms } \\
\text { - Implementation of a web-based CRM software to } \\
\text { handle customer complaints with a centralised server } \\
\text { helped minimise the need for multiple customer care } \\
\text { centres } \\
\text { - Formal trainings and one-on-one trainings were } \\
\text { provided for customer care executives by FEDCO } \\
\text { as capacity-building exercise to improve service } \\
\text { experience with customers } \\
\text { - Quality team was set up to check and verify customer } \\
\text { resolution timelines at the offices of line men }\end{array}$ & $\begin{array}{l}\text { Focus on customer } \\
\text { care through both } \\
\text { technology and } \\
\text { human resource } \\
\text { interventions- } \\
\text { especially } \\
\text { considering } \\
\text { FEDCO's operation } \\
\text { as a distribution } \\
\text { franchisee in } \\
\text { smaller urban areas }\end{array}$ \\
\hline
\end{tabular}




\subsection{RECOMMENDATIONS}

\subsubsection{Structural Reforms}

" Greater autonomy for state-owned discoms: For a state-owned utility to succeed, there should be a clear separation between utility and state. The utility should have operational and financial autonomy. Good corporate governance practices, including the use of independent directors, can help ensure such separation. The performance of state-owned discoms is also determined by the ability of the respective SERC to revise tariff frequently and adequately.

- Distribution franchisee: There can be a variety of distribution franchisees, from models that are essentially outsourcing revenue collection to taking care of all distribution functions (including capital infusion), in a defined area. In rural areas, private investors might not find it attractive to become licensees, but a franchisee model might be attractive. This model was successfully implemented in Bhiwandi, where there have been rapid improvements in metering, billing, and collection, and a reduction in loss. In Odisha, the franchisee model was able to achieve a significant improvement in performance, even with a large agricultural and rural load.

" Distribution licensee/company: The recent Budget announcement delicenses distribution and proposes to allow companies non-discriminatory access to the distribution system. While a licensee model requires a high financial capacity from the private investor, a distribution company model may not do so. In Delhi, factors such as the financial capacity of the private investor, the homogeneity of the customer mix, and their relatively higher capacity to pay, were all relevant to the success of the licensee model.

- Increasing competition: Discoms have a monopoly in their area of functioning. Delicensing distribution can introduce competition and enable retail choice for customers. This reform can be challenging and should be accompanied with careful market design. The feasibility of competition will depend on the size of the market, the nature of the demand, the efficiency of the incumbent, potential for growth, etc.

- Vertical unbundling: Even where there has been de jure unbundling of stateowned power utilities, they may continue to act as de facto integrated utilities. Vertical unbundling enables transparency in operations of the discom. It can focus attention to the parts of the utility (generation, transmission or distribution) that require reform. In states such as Gujarat, the unbundling was an important step towards improving the performance of discoms. Vertical unbundling can also be a first step towards implementing privatisation or a franchisee model, if desired.

- PPP models can be useful in loss-making areas, where commercial operation might not be feasible without support in the form of Viability Gap Funding (VGF) from the government. For instance, in a rural area with high losses, the government could invite bids from private entities and specify the minimum service quality they would need to provide. 


\subsubsection{Regulatory Reforms}

- An effective SERC is essential to a well-functioning distribution sector. The state governments should promote autonomy, competence, and transparency of the SERC. Tariffs should be regularly revised to ensure that they fairly reflect the actual fixed and variable costs. Rapidly changing fuel costs should be adjusted through fuel surcharges determined through a transparent process. No new regulatory assets should be created. The existing regulatory assets should be cleared over a defined schedule over the next 3-5 years through appropriate tariff changes. One way that has been suggested to insulate the regulatory functions from political pressures is to create regional electricity regulatory commissions.

- DBT can help improve efficiency and reduce leakages. It has recently been implemented in parts of Madhya Pradesh. The respective state government should prescribe the details of the DBT scheme. DBT should not be imposed on consumers. Instead, consumers should be able to choose whether to opt for it or not. For those who do not opt for it, the supply of subsidised electricity should continue. The DBT scheme could, for instance, be structured such that consumers do not stand to lose their current benefits but are paid more for efficient use of electricity, such as the Paani Bachao Paise Kamao scheme in Punjab. This will de-risk the consumers. Over time, consumers will see others benefitting and they will be encouraged to adopt the DBT regime.

\subsubsection{Operational Reforms}

- Reducing power procurement costs: Discoms should optimise their power purchase by procuring from the markets as suitable, and they should be rewarded for efficiency gains from the use of the market. The discoms should develop the human resources and daily liquidity that are required to use this relatively new facility. As long as the markets continue to provide low-cost power, discoms should not sign new expensive long-term thermal PPAs. States such as Chhattisgarh, Gujarat, Maharashtra, and Uttar Pradesh have banned new thermal PPAs till 2022. Discoms should use ToD tariffs to incentivise changes in demand patterns. Dynamic tariffs, enabled by advanced metering and a smart grid, can reduce power purchase costs and help manage peak loads.

" Billing efficiency: Many discoms need to improve their billing efficiency through better metering. They should fully utilise the revamped central government reform scheme to achieve 100 percent metering using prepaid/smart meters while being careful of guarding against cybersecurity threats.

- Collection efficiency: Discoms should target 100 percent collection efficiency. Theft can be reduced through concerted action by the discom and the state. Prepaid metering can help reduce pilferage and increase collection, as demonstrated in Manipur. Many state government departments and municipalities are also major defaulters in payments. Discoms should follow up tenaciously to collect current bills as well as arrears. 
- Reduce technical losses: Discoms may reduce their technical losses through investment by improving their grid (including upgrading conductors, hightension lines, and right-sizing transformers) and through the implementation of appropriate monitoring technologies, as was done effectively in Gujarat. This is expected to be a major component of the revamped central government reform scheme announced in the Budget, and the state discoms should aggressively use this support to upgrade their distribution infrastructure.

- Agricultural demand management: States with large rural or agricultural consumer bases such as Rajasthan, Andhra Pradesh, Gujarat, Karnataka and Maharashtra have benefited from separating feeders for agricultural use from non-agricultural use. Investment in feeder separation has been encouraged by the government at the Centre through DDUGJY. Further, solar pump deployment has also received a push through PM-KUSUM scheme. Discoms can significantly improve their financial situation by encouraging the use of solar pumps for agriculture.

\subsubsection{Renewable Energy Integration Reforms}

- Solar and wind power are intermittent sources of power. Even more conventional power sources (coal, natural gas, hydroelectric, or nuclear) also have distinctive characteristics such as different ramp rates and varying abilities to function efficiently at different levels of output. In order to increase the firmness of RE power, reduce their power procurement cost, and handle this variety of power sources, discoms can deploy large-scale energy storage or use hybrid projects such as solar/wind. Storage can be provided by battery systems or pumped hydro-storage systems. Curtailment of renewable power can be reduced by improving transmission grid, accounting for dynamic changes in transmission capacity, and by retrofitting old thermal plants to enable them to operate at lower loads. Discoms need to develop better RE forecasting capabilities to reduce their deviation costs and reduce the need for real-time balancing.

" Currently, many discoms and regulators fear that the rise of RTS can harm their revenue stream. Discoms should be fairly compensated for the additional expenses they need to incur to integrate RTS power generation. Further, tariffs for RTS should be set so that all consumers and producers face fair and relevant price signals as relevant to their state. Off-grid solar power plants are simpler and cheaper than grid-connected solar plants, though they may require storage. Such off-grid solar plants should receive greater policy encouragement.

" While the grid has reached most households, the quality and availability of power is still poor in many remote areas. In such areas, mini and micro-grids can provide more predictable power. Mini-grids can also be used to provide greater resilience to critical infrastructure. Generally, the cost of mini-grid power is much higher than power from discom. A PPP model can be explored in such remote areas, with the government providing VGF (or charging a premium, as the case may be) in return for the concessionaire supplying power at a specified 
rate while meeting service quality targets. The mini-grid could also act as a distribution franchisee. Another possibility is that the mini-grid could be run by a well-capacitated local government, with support from the state government.

\subsubsection{Managerial Reforms}

- Discoms should take proactive steps to improve customer relations. Easily accessible call centres, convenient bill payment facilities, and accurate billing can help reduce customer dissatisfaction and increase revenue.

- Energetic and enthusiastic employees are key to the financial and operational success of a discom. Performance incentives should be designed to align the employees with the interests of the organisation. Zones or circles in the discom could be treated as profit centres, with the employees given commensurate autonomy as well as responsibilities. This can bring in a sense of ownership among employees about running the business profitably.

" The operation and management of the power distribution business are quite complex. They require expertise in a variety of fields: engineering, finance, billing and collection, human resources, administration, etc. Some organisations have been established to provide training (such as the National Power Training Institute, and the Tata Power DDL Learning Centre). There is a need to augment the capacity to provide training in these fields.

\subsection{CONCLUSION}

The Indian power sector is one of the largest and most complicated in the world. External expertise, structural frameworks, and new technology are required but they are not sufficient to drive India's power sector transition. Similarly, a push to retail choice through separation of content and carriage may not necessarily result in the full set of theoretical benefits touted.

One key lesson from the history of the power sector in India is that the country is too large and diverse for a one-size-fits-all approach. A flexible and home-grown approach to reform, which is supported by state and central political will, and which allows for 'learning by doing', will be instrumental in determining the success of reforms. 


\section{0}

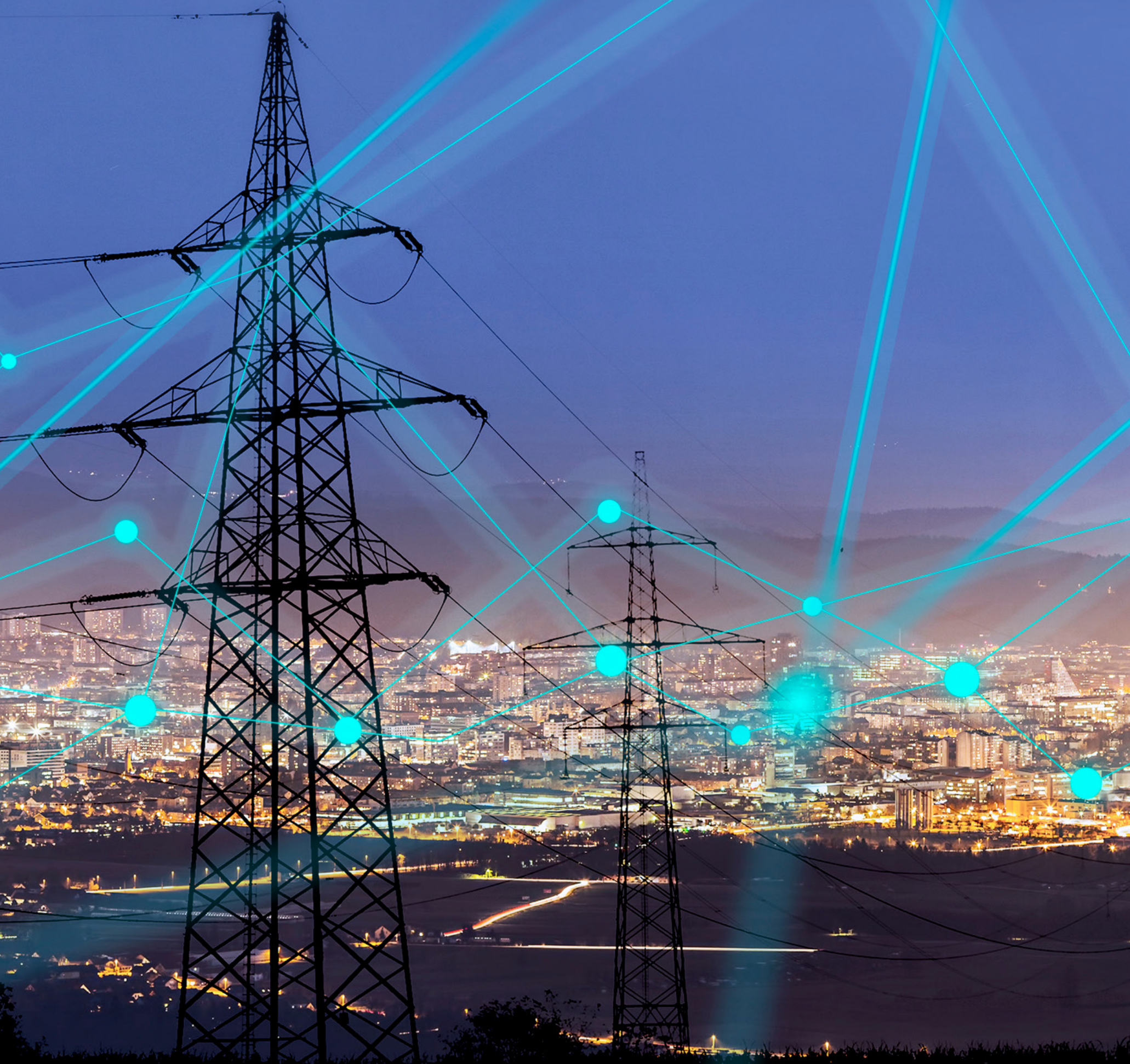




\section{Appendix}

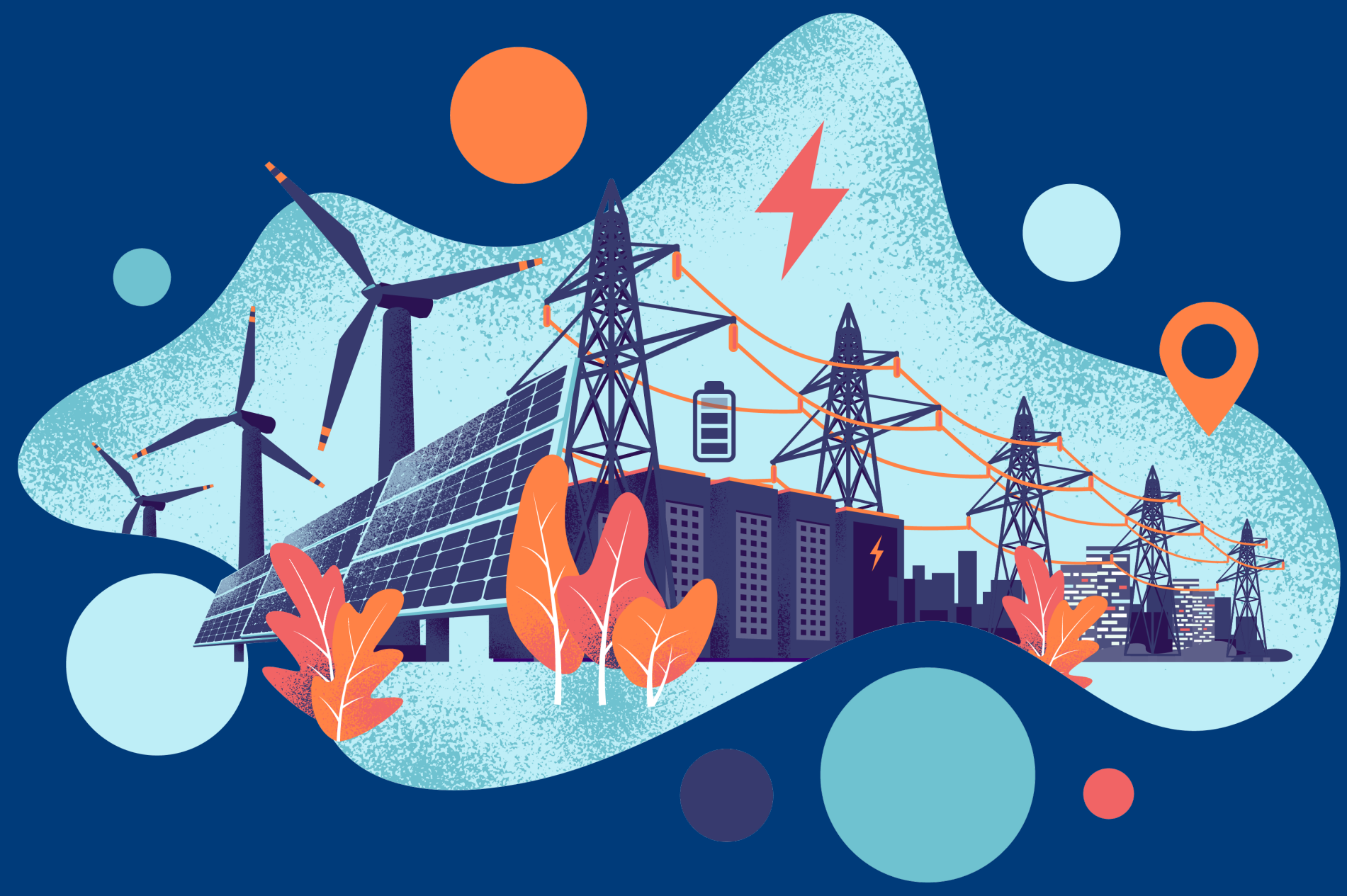




\section{APPENDIX 1: DISCOM PROFITABILITY 2009-10 TO 2018-19 (INCLUDING TARIFF SUBSIDY RECEIVED, IN ₹ CRORE)}

\begin{tabular}{|c|c|c|c|c|c|c|c|c|c|c|c|}
\hline \multicolumn{12}{|c|}{ Profit After Tax including tariff subsidy received (In Crore ₹) } \\
\hline & & & & & & & & \multicolumn{4}{|c|}{ UDAY Period } \\
\hline Region & State & $\begin{array}{c}2009- \\
10\end{array}$ & $\begin{array}{c}2010- \\
11\end{array}$ & $\begin{array}{c}2011- \\
12\end{array}$ & $\begin{array}{c}2012- \\
13\end{array}$ & $\begin{array}{c}2013- \\
14\end{array}$ & $\begin{array}{c}2014- \\
15\end{array}$ & $\begin{array}{c}2015- \\
16\end{array}$ & $\begin{array}{c}2016- \\
17\end{array}$ & $\begin{array}{c}2017- \\
18\end{array}$ & $\begin{array}{c}2018- \\
19\end{array}$ \\
\hline East & Jharkhand & -707 & -723 & $-3,211$ & $-2,668$ & $-4,021$ & -474 & $-1,151$ & $-1,741$ & -212 & -751 \\
\hline East & Bihar & $-1,412$ & $-1,332$ & $-2,662$ & $-1,228$ & -343 & $-1,239$ & $-1,073$ & $-1,257$ & $-1,872$ & $-1,163$ \\
\hline East & Odisha & -241 & -216 & -423 & -559 & -342 & -881 & -931 & -912 & -793 & $-1,539$ \\
\hline East & West Bengal & 71 & 95 & 73 & 82 & 19 & 20 & 137 & -175 & 72 & -14 \\
\hline East & Sikkim & -9 & -23 & -17 & 39 & 33 & -35 & -182 & -115 & -29 & -3 \\
\hline NER & Manipur & -145 & -204 & -307 & -315 & -194 & -30 & -20 & -15 & -8 & -19 \\
\hline NER & $\begin{array}{l}\text { Arunachal } \\
\text { Pradesh }\end{array}$ & -212 & -182 & -274 & -255 & -428 & -257 & -40 & -324 & -429 & -428 \\
\hline NER & Nagaland & -108 & -179 & -214 & -212 & -191 & -315 & -15 & -62 & -62 & -325 \\
\hline NER & Mizoram & -142 & -158 & -127 & -200 & -192 & -192 & -122 & -147 & 87 & -83 \\
\hline NER & Meghalaya & -56 & -91 & -204 & -221 & -295 & -198 & -192 & -343 & -287 & -203 \\
\hline NER & Tripura & -11 & -130 & -157 & -107 & -107 & -102 & -100 & 40 & 28 & 21 \\
\hline NER & Assam & -303 & -486 & -558 & -568 & -693 & -578 & -194 & -58 & 302 & 311 \\
\hline North & Rajasthan & $-11,006$ & $-21,370$ & $-19,572$ & $-12,351$ & $-15,645$ & $-12,474$ & $-12,784$ & $-3,468$ & 686 & -523 \\
\hline North & $\begin{array}{l}\text { Jammu \& } \\
\text { Kashmir }\end{array}$ & $-2,106$ & $-2,167$ & $-3,037$ & $-3,129$ & $-3,375$ & $-4,114$ & $-4,278$ & $-4,063$ & $-2,999$ & $-2,902$ \\
\hline North & Delhi & 615 & 801 & 481 & 356 & 353 & 418 & 227 & 426 & 507 & 787 \\
\hline North & Uttar Pradesh & $-5,260$ & $-3,967$ & $-9,225$ & $-9,778$ & $-16,725$ & $-6,798$ & $-2,522$ & $-3,321$ & $-5,002$ & $-6,031$ \\
\hline North & Haryana & $-1,592$ & $-1,084$ & $-13,203$ & $-3,649$ & $-3,554$ & $-2,117$ & -808 & -193 & 412 & 281 \\
\hline North & $\begin{array}{l}\text { Himachal } \\
\text { Pradesh }\end{array}$ & -153 & -502 & -513 & -340 & -137 & -114 & 391 & -170 & -44 & 99 \\
\hline North & Uttarakhand & -527 & -204 & -55 & -16 & 323 & -260 & -95 & -289 & -229 & -553 \\
\hline North & Punjab & $-1,302$ & $-1,640$ & -459 & 94 & 249 & $-1,067$ & $-2,558$ & $-3,412$ & $-2,618$ & 363 \\
\hline South & Tamil Nadu & $-10,295$ & $-11,907$ & $-13,308$ & $-12,064$ & $-14,052$ & $-12,757$ & $-5,787$ & $-4,349$ & $-7,761$ & $-12,623$ \\
\hline South & Andhra Pradesh & $-3,641$ & $-2,177$ & $-4,023$ & $-17,522$ & $-1,379$ & $-2,549$ & $-3,933$ & $-2,712$ & -545 & $-16,736$ \\
\hline South & Telangana & & & & & & $-2,912$ & $-3,674$ & $-6,209$ & $-6,387$ & $-9,020$ \\
\hline South & Puducherry & -47 & -134 & -164 & -308 & 51 & 104 & 6 & -8 & 5 & -39 \\
\hline South & Karnataka & -425 & 9 & -82 & -905 & -534 & 84 & -132 & $-1,920$ & $-2,003$ & $-1,825$ \\
\hline South & Kerala & 241 & 241 & 241 & 241 & 116 & $-1,273$ & -697 & $-1,495$ & -784 & -290 \\
\hline West & Madhya Pradesh & $-3,343$ & $-2,157$ & $-2,920$ & $-4,452$ & $-6,376$ & $-5,001$ & $-5,474$ & $-1,112$ & $-5,192$ & $-9,390$ \\
\hline West & Goa & 16 & -79 & -271 & -285 & -4 & -17 & -286 & -283 & 26 & -172 \\
\hline West & Chhattisgarh & -351 & -581 & $-2,012$ & -498 & -630 & $-1,554$ & 24 & -573 & -510 & $-1,183$ \\
\hline West & Maharashtra & $-1,085$ & $-1,505$ & -808 & -871 & -280 & -366 & $-2,442$ & -765 & 1,620 & 2,413 \\
\hline West & Gujarat & 49 & 104 & 133 & 71 & 95 & 108 & 84 & 279 & 425 & 184 \\
\hline Total & & $-43,487$ & $-51,948$ & $-76,878$ & $-71,618$ & $-68,258$ & $-56,940$ & $-48,621$ & $-38,746$ & $-33,596$ & $-61,356$ \\
\hline
\end{tabular}

(Source: $P F C^{140}$ ) 


\section{APPENDIX 2: DISCOM ACS-ARR GAP 2008-09 TO 2018-19}

\begin{tabular}{|c|c|c|c|c|c|c|c|c|c|c|c|c|}
\hline \multicolumn{13}{|c|}{ ACS-ARR Gap (₹/kWh) } \\
\hline \multirow[b]{2}{*}{ Region } & \multirow[b]{2}{*}{ State } & \multirow[b]{2}{*}{ 2008-09 } & \multirow[b]{2}{*}{ 2009-10 } & \multirow[b]{2}{*}{ 2010-11 } & \multirow[b]{2}{*}{ 2011-12 } & \multirow[b]{2}{*}{ 2012-13 } & \multirow[b]{2}{*}{ 2013-14 } & \multirow[b]{2}{*}{ 2014-15 } & \multicolumn{4}{|c|}{ UDAY Period } \\
\hline & & & & & & & & & 2015-16 & 2016-17 & 2017-18 & 2018-19 \\
\hline East & Jharkhand & $₹ 1.38$ & $₹ 0.16$ & $₹ 1.08$ & $₹ 3.48$ & $₹ 2.49$ & $₹ 1.96$ & $₹ 0.66$ & $₹ 1.61$ & $₹ 1.39$ & $₹ 0.16$ & $₹ 0.58$ \\
\hline East & Bihar & $₹ 0.99$ & $₹ 1.48$ & $₹ 1.28$ & ₹ 2.06 & $₹ 0.27$ & $₹ 0.33$ & $₹ 0.76$ & ₹ 0.62 & $₹ 0.51$ & ₹ 0.68 & $₹ 0.39$ \\
\hline East & Odisha & $₹ 0.18$ & $₹ 0.15$ & $₹ 0.31$ & $₹ 0.45$ & $₹ 0.48$ & $₹ 0.16$ & $₹ 0.46$ & $₹ 0.57$ & $₹ 0.38$ & ₹ 0.32 & $₹ 0.60$ \\
\hline East & West Bengal & $-₹ 0.02$ & $₹ 0.11$ & $-₹ 0.03$ & $₹ 0.44$ & $-₹ 0.12$ & $₹ 0.37$ & $₹ 0.12$ & $-₹ 0.08$ & $₹ 0.36$ & $₹ 0.22$ & $₹ 0.30$ \\
\hline East & Sikkim & ₹ 0.09 & ₹ 0.55 & ₹ 0.79 & $₹ 0.37$ & -₹ 0.24 & ₹ 0.28 & ₹ 0.54 & $₹ 1.06$ & $₹ 1.20$ & $₹ 0.25$ & $₹ 0.02$ \\
\hline NER & Manipur & ₹ 2.87 & $₹ 1.50$ & $₹ 1.93$ & ₹ 5.13 & ₹ 6.30 & $₹ 3.49$ & $₹ 0.18$ & $₹ 0.50$ & $₹ 0.06$ & -₹ 0.02 & ₹ 0.10 \\
\hline NER & $\begin{array}{l}\text { Arunachal } \\
\text { Pradesh }\end{array}$ & $₹ 0.47$ & ₹ 4.37 & $₹ 2.97$ & $₹ 4.44$ & $₹ 4.05$ & $₹ 6.88$ & $₹ 4.09$ & $₹ 3.50$ & ₹ 3.65 & $₹ 4.64$ & $₹ 4.27$ \\
\hline NER & Nagaland & $₹ 1.40$ & ₹ 2.32 & $₹ 3.25$ & $₹ 3.18$ & ₹ 4.66 & $₹ 1.49$ & $₹ 7.21$ & $₹ 5.68$ & $₹ 0.81$ & $₹ 0.81$ & $₹ 4.09$ \\
\hline NER & Mizoram & $₹ 1.81$ & $₹ 3.79$ & $₹ 3.79$ & $₹ 2.78$ & ₹ 4.26 & $₹ 4.07$ & $₹ 3.63$ & -₹ 0.99 & $₹ 2.12$ & -₹ 1.30 & ₹ 1.18 \\
\hline NER & Meghalaya & $₹ 0.19$ & $₹ 0.90$ & ₹ 0.98 & $₹ 1.69$ & ₹ 3.87 & $₹ 1.40$ & $₹ 1.59$ & $₹ 1.19$ & $₹ 1.66$ & $₹ 1.16$ & $₹ 0.85$ \\
\hline NER & Tripura & $-₹ 0.35$ & ₹ 0.15 & $₹ 1.22$ & $₹ 1.47$ & ₹ 0.94 & $₹ 0.59$ & $₹ 0.52$ & ₹ 0.35 & $-₹ 0.15$ & $-₹ 0.09$ & -₹ 0.06 \\
\hline NER & Assam & ₹ 0.24 & $₹ 0.75$ & $₹ 0.92$ & $₹ 1.13$ & $₹ 1.03$ & $₹ 1.13$ & ₹ 0.94 & $₹ 0.59$ & $₹ 0.06$ & $₹ 0.28$ & $₹ 0.02$ \\
\hline North & Rajasthan & $₹ 1.84$ & ₹ 2.58 & ₹ 2.09 & $₹ 4.04$ & $₹ 1.89$ & ₹ 2.74 & $₹ 1.94$ & $₹ 1.59$ & $₹ 1.79$ & $₹ 1.49$ & $₹ 1.50$ \\
\hline North & $\begin{array}{l}\text { Jammu \& } \\
\text { Kashmir }\end{array}$ & $₹ 1.66$ & ₹ 2.25 & $₹ 2.39$ & ₹ 2.80 & ₹ 2.04 & $₹ 1.84$ & $₹ 3.26$ & ₹ 3.24 & ₹ 2.65 & $₹ 1.85$ & $₹ 1.72$ \\
\hline North & Delhi & -₹ 0.24 & $₹ 0.69$ & $₹ 1.08$ & $₹ 1.84$ & $-₹ 0.13$ & $-₹ 0.20$ & -₹ 0.19 & -₹ 0.10 & -₹ 0.07 & -₹ 0.07 & -₹ 0.21 \\
\hline North & Uttar Pradesh & $₹ 0.87$ & $₹ 1.34$ & $₹ 0.87$ & $₹ 1.10$ & $₹ 1.85$ & ₹ 2.11 & $₹ 1.44$ & $₹ 1.06$ & ₹ 0.33 & $₹ 0.47$ & $₹ 0.60$ \\
\hline North & Haryana & $₹ 0.55$ & ₹ 0.47 & $₹ 0.28$ & $₹ 1.01$ & ₹ 0.94 & $₹ 0.86$ & $₹ 0.53$ & $₹ 0.26$ & $₹ 0.04$ & $-₹ 0.08$ & -₹ 0.05 \\
\hline North & $\begin{array}{l}\text { Himachal } \\
\text { Pradesh }\end{array}$ & -₹ 0.06 & $₹ 0.30$ & $₹ 0.36$ & $₹ 0.74$ & ₹ 0.11 & $₹ 0.25$ & $₹ 0.28$ & $₹ 0.08$ & $₹ 0.18$ & $₹ 0.03$ & -₹ 0.07 \\
\hline North & Uttarakhand & $₹ 0.55$ & $₹ 0.65$ & ₹ 0.35 & $₹ 0.64$ & $₹ 0.07$ & -₹ 0.28 & $₹ 0.18$ & -₹ 0.22 & $₹ 0.24$ & $₹ 0.18$ & $₹ 0.38$ \\
\hline North & Punjab & $₹ 0.30$ & ₹ 0.34 & ₹ 0.42 & $₹ 0.23$ & -₹ 0.19 & $-₹ 0.01$ & ₹ 0.32 & $₹ 0.65$ & $₹ 0.65$ & $₹ 0.50$ & -₹ 0.05 \\
\hline South & Tamil Nadu & $₹ 1.22$ & $₹ 1.56$ & $₹ 1.79$ & $₹ 2.11$ & $₹ 1.51$ & $₹ 1.85$ & $₹ 1.63$ & $₹ 0.69$ & $₹ 0.50$ & $₹ 1.43$ & $₹ 1.88$ \\
\hline South & $\begin{array}{l}\text { Andhra } \\
\text { Pradesh }\end{array}$ & ₹ 0.94 & $₹ 0.68$ & ₹ 0.64 & $₹ 1.24$ & $₹ 1.12$ & $₹ 0.35$ & $₹ 0.75$ & $₹ 0.88$ & $₹ 0.52$ & $₹ 0.09$ & ₹ 2.69 \\
\hline South & Puducherry & $₹ 0.42$ & $₹ 0.28$ & $-₹ 0.08$ & $₹ 0.64$ & ₹ 0.87 & $₹ 0.32$ & -₹ 0.31 & $₹ 0.41$ & $₹ 0.03$ & -₹ 0.02 & $₹ 0.13$ \\
\hline South & Karnataka & $₹ 0.48$ & ₹ 0.30 & ₹ 0.28 & ₹ 0.39 & $₹ 0.22$ & ₹ 0.27 & $₹ 0.13$ & -₹ 0.02 & $₹ 0.53$ & ₹ 0.36 & $₹ 0.68$ \\
\hline South & Telangana & & & & & & & $₹ 0.46$ & ₹ 0.94 & $₹ 1.23$ & $₹ 1.17$ & $₹ 1.45$ \\
\hline South & Kerala & -₹ 0.15 & -₹ 0.40 & -₹ 0.08 & -₹ 0.10 & -₹ 0.16 & $₹ 0.59$ & ₹ 0.69 & $₹ 0.22$ & $₹ 0.62$ & $₹ 0.32$ & $₹ 0.11$ \\
\hline West & $\begin{array}{l}\text { Madhya } \\
\text { Pradesh }\end{array}$ & $₹ 1.28$ & $₹ 1.07$ & $₹ 0.78$ & $₹ 0.79$ & $₹ 0.88$ & $₹ 1.21$ & $₹ 0.98$ & $₹ 0.95$ & $₹ 0.81$ & $₹ 0.88$ & $₹ 1.41$ \\
\hline West & Goa & -₹ 0.46 & -₹ 0.25 & -₹ 0.06 & $₹ 0.76$ & $₹ 0.83$ & $₹ 0.51$ & $₹ 0.12$ & $-₹ 0.03$ & $₹ 0.70$ & $-₹ 0.06$ & $₹ 0.39$ \\
\hline West & Chhattisgarh & -₹ 0.15 & $₹ 0.13$ & $₹ 0.28$ & $₹ 0.71$ & $₹ 0.31$ & ₹ 0.24 & $₹ 0.88$ & $₹ 0.40$ & $₹ 0.21$ & $₹ 0.16$ & $₹ 0.35$ \\
\hline West & Maharashtra & $₹ 0.51$ & ₹ 0.22 & $₹ 0.31$ & ₹ 0.21 & $-₹ 0.06$ & $₹ 0.05$ & $₹ 0.30$ & $₹ 1.95$ & $₹ 0.59$ & $₹ 0.31$ & $-₹ 0.16$ \\
\hline West & Gujarat & $₹ 0.04$ & -₹ 0.02 & $-₹ 0.02$ & $₹ 0.08$ & $-₹ 0.10$ & $₹ 0.01$ & -₹ 0.07 & -₹ 0.05 & $-₹ 0.05$ & -₹ 0.06 & $-₹ 0.02$ \\
\hline \multicolumn{2}{|c|}{ All India Average } & $₹ 0.64$ & $₹ 0.67$ & $₹ 0.62$ & $₹ 1.04$ & $₹ 0.48$ & $₹ 0.79$ & $₹ 0.70$ & $₹ 0.76$ & $₹ 0.58$ & $₹ 0.53$ & $₹ 0.72$ \\
\hline
\end{tabular}

(Source: PFC ${ }^{141}$ ) 


\section{APPENDIX 3: OPERATIONAL AND FINANCIAL POSITIONS OF DISCOMS IN INDIAN STATES FOR 2018-19}

\begin{tabular}{|c|c|c|c|c|c|c|c|c|c|c|}
\hline \multirow[b]{2}{*}{ States } & \multirow[b]{2}{*}{$\begin{array}{l}\text { AT\&C } \\
\text { Losses }\end{array}$} & \multicolumn{2}{|c|}{$\begin{array}{l}\text { Billing / } \\
\text { Collection }\end{array}$} & \multicolumn{2}{|c|}{$\begin{array}{c}\text { Power } \\
\text { Purchase } \\
\text { (₹ per KWh) }\end{array}$} & \multicolumn{3}{|c|}{$\begin{array}{c}\text { Revenue } \\
\text { (₹ per KWh) }\end{array}$} & \multicolumn{2}{|c|}{ Performance } \\
\hline & & $\begin{array}{c}\text { Billing } \\
\text { Efficiency }\end{array}$ & $\begin{array}{l}\text { Collection } \\
\text { Efficiency }\end{array}$ & $\begin{array}{l}\text { Average } \\
\text { Power } \\
\text { Purchase } \\
\text { Cost (APPC) }\end{array}$ & $\begin{array}{l}\text { Average } \\
\text { Cost of } \\
\text { Supply } \\
\text { (ACS) }\end{array}$ & $\begin{array}{l}\text { Revenue } \\
\text { from } \\
\text { Sales }\end{array}$ & $\begin{array}{c}\text { Tariff } \\
\text { Subsidy } \\
\text { Received }\end{array}$ & $\begin{array}{l}\text { Adjusted } \\
\text { ARR }\end{array}$ & $\begin{array}{l}\text { ACS-ARR } \\
\text { Gap ₹ per } \\
\text { KWh) }\end{array}$ & $\begin{array}{c}\text { Tariff } \\
\text { subsidy as } \\
\text { share of } \\
\text { revenue }\end{array}$ \\
\hline $\begin{array}{l}\text { Andhra } \\
\text { Pradesh }\end{array}$ & $25.7 \%$ & $92.3 \%$ & $80.53 \%$ & $₹ 7.15$ & $₹ 8.75$ & $₹ 5.00$ & $₹ 1.11$ & $₹ 6.54$ & $₹ 2.21$ & $17 \%$ \\
\hline Assam & $19.9 \%$ & $80.3 \%$ & $99.80 \%$ & $₹ 6.77$ & $₹ 8.46$ & $₹ 6.64$ & $₹ 0.35$ & $₹ 8.05$ & $₹ 0.41$ & $4 \%$ \\
\hline Bihar & $30.9 \%$ & $69.8 \%$ & $98.88 \%$ & $₹ 7.08$ & ₹ 8.88 & $₹ 4.81$ & $₹ 1.91$ & $₹ 7.68$ & $₹ 1.20$ & $25 \%$ \\
\hline Chhattisgarh & $27.3 \%$ & $81.9 \%$ & $88.79 \%$ & $₹ 4.79$ & $₹ 5.76$ & $₹ 4.39$ & $₹ 1.01$ & $₹ 5.75$ & $₹ 0.01$ & $18 \%$ \\
\hline Gujarat & $14.0 \%$ & $86.6 \%$ & $99.38 \%$ & $₹ 5.44$ & $₹ 6.02$ & $₹ 5.00$ & $₹ 0.85$ & $₹ 6.05$ & -₹ 0.03 & $14 \%$ \\
\hline Haryana & $18.1 \%$ & $81.9 \%$ & $100.00 \%$ & $₹ 5.95$ & $₹ 7.08$ & $₹ 4.99$ & $₹ 1.60$ & $₹ 7.14$ & -₹ 0.06 & $22 \%$ \\
\hline $\begin{array}{l}\text { Himachal } \\
\text { Pradesh }\end{array}$ & $11.4 \%$ & $88.6 \%$ & $100.00 \%$ & $₹ 3.65$ & $₹ 5.83$ & $₹ 5.16$ & $₹ 0.38$ & $₹ 5.84$ & $-₹ 0.01$ & $7 \%$ \\
\hline Jharkhand & $28.6 \%$ & $77.1 \%$ & $92.59 \%$ & $₹ 6.05$ & $₹ 7.30$ & $₹ 4.37$ & $₹ 1.35$ & $₹ 6.49$ & $₹ 0.81$ & $21 \%$ \\
\hline Karnataka & $19.8 \%$ & $87.1 \%$ & $92.02 \%$ & $₹ 5.93$ & $₹ 7.35$ & $₹ 4.68$ & $₹ 2.04$ & $₹ 7.01$ & $₹ 0.34$ & $29 \%$ \\
\hline Kerala & $9.1 \%$ & $90.9 \%$ & $100.00 \%$ & $₹ 3.49$ & $₹ 6.34$ & $₹ 5.79$ & $₹ 0.00$ & $₹ 6.21$ & $₹ 0.13$ & $0 \%$ \\
\hline $\begin{array}{l}\text { Madhya } \\
\text { Pradesh }\end{array}$ & $36.0 \%$ & $72.4 \%$ & $88.36 \%$ & $₹ 6.11$ & $₹ 8.43$ & $₹ 4.04$ & $₹ 2.31$ & $₹ 6.86$ & $₹ 1.57$ & $34 \%$ \\
\hline Maharashtra & $14.7 \%$ & $85.3 \%$ & $100.00 \%$ & $₹ 5.68$ & $₹ 7.51$ & $₹ 5.55$ & $₹ 0.93$ & $₹ 7.58$ & -₹ 0.07 & $12 \%$ \\
\hline Manipur & $29.8 \%$ & $74.1 \%$ & $94.71 \%$ & $₹ 6.68$ & $₹ 8.27$ & $₹ 4.13$ & $₹ 2.99$ & ₹ 8.13 & ₹ 0.14 & $37 \%$ \\
\hline Meghalaya & $35.2 \%$ & $64.8 \%$ & $100.00 \%$ & $₹ 5.43$ & $₹ 6.82$ & $₹ 4.98$ & $₹ 0.00$ & $₹ 5.65$ & ₹ 1.17 & $0 \%$ \\
\hline Punjab & $11.3 \%$ & $88.7 \%$ & $100.00 \%$ & $₹ 4.89$ & ₹ 6.92 & $₹ 4.62$ & $₹ 1.82$ & ₹ 6.89 & $₹ 0.03$ & $26 \%$ \\
\hline Rajasthan & $28.3 \%$ & $79.3 \%$ & $90.49 \%$ & ₹ 6.12 & ₹ 8.74 & $₹ 4.32$ & $₹ 1.72$ & $₹ 7.25$ & $₹ 1.49$ & $24 \%$ \\
\hline Tamil Nadu & $17.3 \%$ & $83.5 \%$ & $99.10 \%$ & $₹ 7.04$ & $₹ 9.76$ & $₹ 6.10$ & $₹ 1.01$ & $₹ 7.40$ & $₹ 2.36$ & $14 \%$ \\
\hline Telangana & $20.0 \%$ & $93.9 \%$ & $85.18 \%$ & $₹ 5.81$ & $₹ 6.99$ & $₹ 4.23$ & $₹ 0.92$ & $₹ 5.55$ & $₹ 1.44$ & $17 \%$ \\
\hline Uttar Pradesh & $33.2 \%$ & $81.3 \%$ & $82.21 \%$ & $₹ 6.53$ & $₹ 7.86$ & $₹ 5.38$ & $₹ 1.14$ & $₹ 7.13$ & $₹ 0.73$ & $16 \%$ \\
\hline Uttarakhand & $16.2 \%$ & $86.2 \%$ & $97.24 \%$ & $₹ 4.81$ & $₹ 5.64$ & $₹ 4.79$ & $₹ 0.00$ & $₹ 5.19$ & $₹ 0.45$ & $0 \%$ \\
\hline West Bengal & $23.0 \%$ & $77.0 \%$ & $100.00 \%$ & $₹ 5.76$ & $₹ 7.22$ & $₹ 6.15$ & $₹ 0.31$ & $₹ 6.81$ & $₹ 0.41$ & $5 \%$ \\
\hline Sikkim & $31.8 \%$ & $70.2 \%$ & $97.11 \%$ & $₹ 2.75$ & $₹ 3.93$ & $₹ 3.90$ & $₹ 0.00$ & $₹ 3.91$ & $₹ 0.02$ & $0 \%$ \\
\hline Goa & $15.7 \%$ & $88.7 \%$ & $95.00 \%$ & $₹ 3.98$ & $₹ 5.42$ & $₹ 4.90$ & $₹ 0.00$ & $₹ 4.97$ & $₹ 0.45$ & $0 \%$ \\
\hline Odisha & $29.2 \%$ & $75.7 \%$ & $93.57 \%$ & ₹ 4.45 & $₹ 6.27$ & $₹ 5.10$ & $₹ 0.00$ & $₹ 5.48$ & $₹ 0.79$ & $0 \%$ \\
\hline $\begin{array}{l}\text { Arunachal } \\
\text { Pradesh }\end{array}$ & $55.5 \%$ & $44.5 \%$ & $100.00 \%$ & $₹ 7.73$ & $₹ 15.58$ & $₹ 3.77$ & $₹ 2.43$ & $₹ 6.20$ & ₹ 9.38 & $39 \%$ \\
\hline Delhi & $9.1 \%$ & $91.4 \%$ & $99.50 \%$ & $₹ 5.46$ & $₹ 7.35$ & $₹ 6.85$ & $₹ 0.54$ & $₹ 7.59$ & $-₹ 0.24$ & $7 \%$ \\
\hline Mizoram & $16.2 \%$ & $83.8 \%$ & $100.00 \%$ & $₹ 5.92$ & $₹ 8.90$ & $₹ 4.95$ & $₹ 2.54$ & $₹ 7.49$ & $₹ 1.41$ & $34 \%$ \\
\hline Nagaland & $40.1 \%$ & $75.0 \%$ & $79.92 \%$ & $₹ 5.45$ & $₹ 12.98$ & $₹ 2.52$ & $₹ 4.81$ & $₹ 7.53$ & $₹ 5.45$ & $64 \%$ \\
\hline $\begin{array}{l}\text { Jammu \& } \\
\text { Kashmir }\end{array}$ & $49.9 \%$ & $61.0 \%$ & $82.06 \%$ & $₹ 6.67$ & $₹ 7.53$ & $₹ 3.16$ & $₹ 1.28$ & $₹ 4.44$ & $₹ 3.09$ & $29 \%$ \\
\hline Tripura & $35.5 \%$ & $68.3 \%$ & $94.43 \%$ & $₹ 4.15$ & $₹ 5.14$ & $₹ 5.03$ & $₹ 0.00$ & $₹ 5.22$ & -₹ 0.08 & $0 \%$ \\
\hline Puducherry & $22.2 \%$ & $86.7 \%$ & $89.65 \%$ & $₹ 4.95$ & $₹ 5.62$ & $₹ 5.51$ & $₹ 0.01$ & $₹ 5.49$ & $₹ 0.13$ & O\% \\
\hline All India & $22.0 \%$ & $83.4 \%$ & $93.49 \%$ & ₹ 5.87 & $₹ 7.55$ & $₹ 5.09$ & ₹ 1.15 & $₹ 6.78$ & $₹ 0.77$ & $17 \%$ \\
\hline
\end{tabular}

(Source: $P F C^{142}$ ) 


\section{APPENDIX 4: DISCOM PERFORMANCE ANALYSIS FOR FY 2019}

\begin{tabular}{|c|c|c|c|c|c|c|}
\hline S.No. & Region & DISCOM & $\begin{array}{l}\text { Profit/ } \\
\text { Loss on } \\
\text { accrual } \\
\text { basis (in } \\
₹ \text { Cr) }\end{array}$ & $\begin{array}{l}\text { Billing } \\
\text { Eff. (\%) }\end{array}$ & $\begin{array}{c}\text { Collection } \\
\text { Eff. (\%) }\end{array}$ & $\begin{array}{c}\text { AT\&C } \\
\text { Losses } \\
(\%)\end{array}$ \\
\hline \multicolumn{7}{|c|}{ Public Discoms } \\
\hline 1 & Andhra Pradesh & APEPDCL & $-4,253$ & 93 & 87 & 18 \\
\hline 2 & Andhra Pradesh & APSPDCL & $-7,681$ & 92 & 77 & 30 \\
\hline 3 & Arunachal Pradesh & Arunachal PD & -428 & 45 & 100 & 56 \\
\hline 4 & Assam & APDCL & 21 & 80 & 100 & 20 \\
\hline 5 & Bihar & NBPDCL & -596 & 73 & 97 & 29 \\
\hline 6 & Bihar & SBPDCL & $-1,813$ & 68 & 100 & 32 \\
\hline 7 & Chhattisgarh & CSPDCL & -42 & 82 & 89 & 27 \\
\hline 8 & Goa & Goa PD & -172 & 89 & 95 & 16 \\
\hline 9 & Gujarat & DGVCL & 39 & 94 & 100 & 6 \\
\hline 10 & Gujarat & MGVCL & 33 & 91 & 100 & 10 \\
\hline 11 & Gujarat & PGVCL & 75 & 80 & 99 & 21 \\
\hline 12 & Gujarat & UGVCL & 37 & 89 & 99 & 12 \\
\hline 13 & Haryana & DHBVN & 95 & 85 & 100 & 15 \\
\hline 14 & Haryana & UHBVN & 186 & 78 & 100 & 22 \\
\hline 15 & Himachal Pradesh & HPSEBL & 4 & 89 & 100 & 11 \\
\hline 16 & Jammu \& Kashmir & JKPDD & $-2,902$ & 61 & 82 & 50 \\
\hline 17 & Jharkhand & JBVNL & -751 & 77 & 93 & 29 \\
\hline 18 & Karnataka & BESCOM & 85 & 88 & 96 & 16 \\
\hline 19 & Karnataka & CESCOM & -209 & 88 & 91 & 20 \\
\hline 20 & Karnataka & GESCOM & 348 & 86 & 85 & 27 \\
\hline 21 & Karnataka & HESCOM & 690 & 85 & 88 & 25 \\
\hline 22 & Karnataka & MESCOM & 56 & 89 & 92 & 18 \\
\hline 23 & Kerala & KSEB & -290 & 91 & 100 & 9 \\
\hline 24 & Madhya Pradesh & MPMKVVCL & $-3,838$ & 63 & 87 & 45 \\
\hline 25 & Madhya Pradesh & MPPKVVCL & -424 & 84 & 91 & 24 \\
\hline 26 & Madhya Pradesh & MPPKVVCL & $-2,897$ & 69 & 86 & 40 \\
\hline 27 & Maharashtra & MSEDCL & 1,097 & 85 & 100 & 15 \\
\hline 28 & Manipur & MSPDCL & -19 & 74 & 95 & 30 \\
\hline 29 & Meghalaya & MePDCL & -203 & 65 & 100 & 35 \\
\hline 30 & Mizoram & Mizoram PD & -83 & 84 & 100 & 16 \\
\hline
\end{tabular}




\begin{tabular}{|c|c|c|c|c|c|c|}
\hline 31 & Nagaland & Nagaland PD & -325 & 75 & 80 & 40 \\
\hline 32 & Odisha & CESU & -429 & 72 & 94 & 32 \\
\hline 33 & Odisha & NESCO Utility & -2 & 81 & 95 & 23 \\
\hline 34 & Odisha & $\begin{array}{l}\text { SOUTHCO } \\
\text { Utility }\end{array}$ & -211 & 70 & 85 & 40 \\
\hline 35 & Odisha & WESCO Utility & -897 & 79 & 96 & 25 \\
\hline 36 & Puducherry & $\begin{array}{l}\text { Puducherry } \\
\text { PD }\end{array}$ & -36 & 87 & 90 & 22 \\
\hline 37 & Punjab & PSPCL & -38 & 89 & 100 & 11 \\
\hline 38 & Rajasthan & AVVNL & 467 & 82 & 94 & 23 \\
\hline 39 & Rajasthan & JDVVNL & 1,234 & 77 & 84 & 35 \\
\hline 40 & Rajasthan & JVVNL & 906 & 79 & 93 & 26 \\
\hline 41 & Sikkim & Sikkim PD & -3 & 70 & 97 & 32 \\
\hline 42 & Tamil Nadu & TANGEDCO & $-12,623$ & 83 & 99 & 17 \\
\hline 43 & Telangana & TSNPDCL & $-3,051$ & 90 & 79 & 29 \\
\hline 44 & Telangana & TSSPDCL & $-4,967$ & 96 & 88 & 16 \\
\hline 45 & Tripura & TSECL & 21 & 68 & 94 & 35 \\
\hline 46 & Uttar Pradesh & DVVNL & $-2,567$ & 79 & 80 & 37 \\
\hline 47 & Uttar Pradesh & KESCO & -450 & 91 & 93 & 15 \\
\hline 48 & Uttar Pradesh & MVVNL & -746 & 78 & 76 & 41 \\
\hline 49 & Uttar Pradesh & PVVNL & $-1,290$ & 85 & 91 & 22 \\
\hline 50 & Uttar Pradesh & PuVVNL & -978 & 80 & 76 & 40 \\
\hline 51 & Uttarakhand & UPCL & -553 & 86 & 97 & 16 \\
\hline 52 & West Bengal & WBSEDCL & -45 & 77 & 100 & 23 \\
\hline \multicolumn{7}{|c|}{ Private Discoms } \\
\hline 53 & Delhi & BRPL & 291 & 91 & 100 & 9 \\
\hline 54 & Delhi & BYPL & 172 & 91 & 99 & 10 \\
\hline 55 & Delhi & TPDDL & 336 & 92 & 100 & 8 \\
\hline 56 & Surat & Torrent Power & \multirow[t]{3}{*}{889} & 100 & 97 & 3 \\
\hline 57 & Dahej & Torrent Power & & 100 & 97 & 4 \\
\hline 58 & Ahmedabad & Torrent Power & & 94 & 100 & 6 \\
\hline
\end{tabular}

(Source: PFC and Annual reports) 


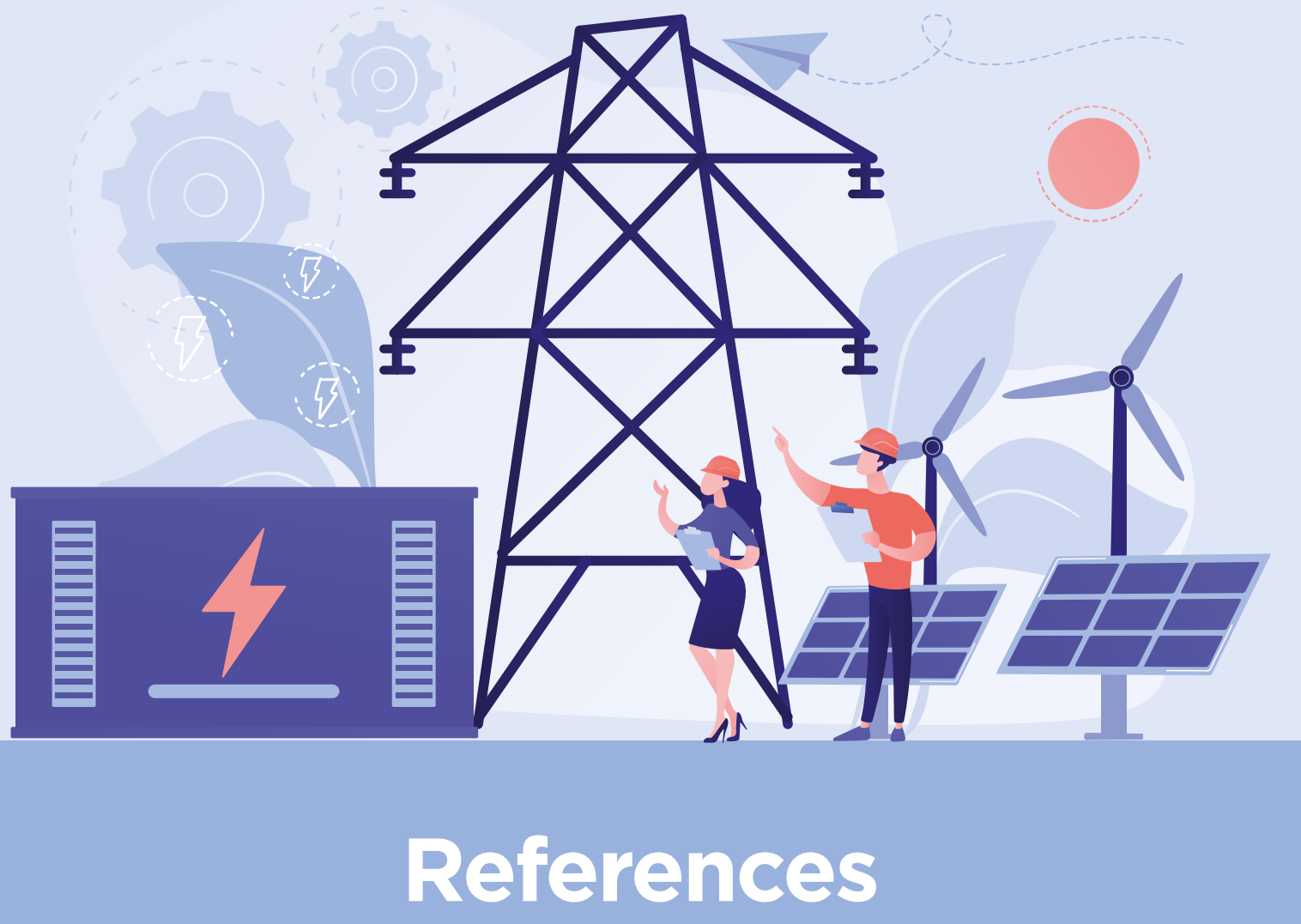

1. ICRA, March 2021. Distribution sector reforms imminent with rising discom debt and dues to gencos. Retrieved from www.icraresearch.in/research/ViewResearchReport/3567

2. Ministry of Power, PFC Consulting. (2020). Payment Ratification And Analysis in Power Procurement for Bringing Transparency in Invoicing of Generators (PRAAPTI). Retrieved from www.praapti.in/

3. The Hindu Busuiness Line. (2021, January). Madhya Pradesh becomes first State to give power subsidy to farmers through DBT. Retrieved from www.thehindubusinessline.com/ news/national/madhya-pradesh-becomes-first-state-to-give-power-subsidy-to-farmers-through-dbt/article33611726.ece

4. Nidhi Bali, Sidhartha Vermani, Vaishali Mishra. 2020. Electricity Access and Benchmarking of distribution utilities in India, New Delhi: Smart Power India-powered by The Rockefeller Foundation

5. PFC. (2020). Report on Performance of State Power Utilities 2018-19. Retrieved from Power Finance Corporation: www.pfcindia.com/DocumentRepository/ckfinder/files/ Operations/Performance_Reports_of_State_Power_Utilities/Report\%20on\%20 Performance\%20of\%20State\%2OPower\%20Utilities\%202018-19.pdf

6. ICRA, March 2021. Distribution sector reforms imminent with rising discom debt and dues to gencos. Retrieved from www.icraresearch.in/research/ViewResearchReport/3567

7. Ministry of Power, PFC Consulting. (2020). Payment Ratification And Analysis in Power Procurement for Bringing Transparency in Invoicing of Generators (PRAAPTI). Retrieved from www.praapti.in/ 
8. EnergyWorld, 2021. Consumers pay Rs 25,000 crore price for high coal tax, keeping power out of GST. Retrieved from https://energy.economictimes.indiatimes.com/news/ coal/consumers-pay-rs-25000-crore-price-for-high-coal-tax-keeping-power-out-ofgst/80596240

9. Wire, 2018. Leaving Electricity Out of GST Regime Costs Indians Nearly ₹30,000 Crore a Year. Retrieved from https://thewire.in/energy/leaving-electricity-gst-regime-costsindians-nearly-rs-30000-crore-year

10. Economic Times, 2020. Government begins deliberations on bringing power sector under GST: Retrieved from https://economictimes.indiatimes.com/industry/energy/ power/govt-begins-deliberations-on-bringing-power-under-gst/articleshow/78303166. $\mathrm{cms}$ ?from $=\mathrm{mdr}$

11. Financial Express, 2020. Budget 2020 offers tax sops for new power companies. Retrieved from www.financialexpress.com/budget/budget-2020-offers-tax-sops-fornew-power-companies/1851344/

12. ET Energyworld, 2020. COVID-19: Power discoms will require subsidies of ₹1 lakh crore in 2020-21. Retrieved from: https://energy.economictimes.indiatimes.com/news/power/ covid-19-power-discoms-will-require-subsidies-of-rs-1-lakh-crore-in-2020-21/75539215

13. Business Standard, 2020. Discoms' dues to generators jump 34\% to ₹ 1.2 trillion amid Covid-19 hit. Retrieved from www.business-standard.com/article/companies/discomsdues-to-generators-jump-34-to-rs-1-2-trillion-amid-covid-19-hit-120120700336_1.html

14. Bloomberg Quint, 2021. Loans Worth ₹1.25 Lakh Crore Sanctioned Under Discoms Liquidity Package. Retrieved from: hwww.bloombergquint.com/business/loans-worthrs-1-25-lakh-cr-sanctioned-under-discoms-liquidity-package-disbursement-at-rs-46k$\mathrm{Cr}$

15. ICRA, March 2021. Distribution sector reforms imminent with rising discom debt and dues to gencos. Retrieved from www.icraresearch.in/research/ViewResearchReport/3567

16. Foster, Vivien, and Anshul Rana. 2020. Rethinking Power Sector Reform in the Developing World. Sustainable Infrastructure Series. Washington, DC: World Bank. doi:10.1596/9781-4648-1442-6. Retrieved from https://openknowledge.worldbank.org/bitstream/handl e/10986/32335/9781464814426.pdf?sequence=10\&isAllowed=y

17. Ministry of Power, 2021. Distribution. Retrieved from https://powermin.gov.in/en/ content/distribution-O

18. Pargal, S., \& Banerjee, S. G. (2014). More Power to India - The Challenge of Electricity Distribution. Washington D.C.: The World Bank.

19. MoP. (2005, February 12). National Electricity Policy. Retrieved from Government of India, Ministry of Power: www.powermin.nic.in/en/content/national-electricity-policy

20. IEA. (2017, May 31). Tariff Policy 2006. Retrieved from www.iea.org/policies/4731-tariff-policy-2006: International Energy Agency

21. Ministry of Power, 2014. Deendayal Upadhyaya Gram Jyoti Yojana. Retrieved from https://powermin.nic.in/sites/default/files/uploads/Deendayal_Upadhyaya_Gram_ Jyoti_Yojana.pdf 
22. Ministry of Power, 2014. Integrated Power Development Scheme. Retrieved from https:// powermin.nic.in/sites/default/files/uploads/Integrated_Power_Development_Scheme. pdf

23. Ministry of Power, 2015. UDAY (Ujwal DISCOM Assurance Yojana) for financial turnaround of Power Distribution Companies. Retrieved from https://powermin.nic.in/pdf/Uday_ Ujjawal_Scheme_for_Operational_and_financial_Turnaround_of_power_distribution_ companies.pdf

24. Kaur, Amandeep, Lekha Chakraborty, Divy Rangan. 2021. Covid-19 Economic Stimulus and State-level Power Sector Performance: Analyzing the Efficiency Parameters. Retrieved from www.nipfp.org.in/media/medialibrary/2021/03/WP_333_2021.pdf

25. Gol (2021, February 1) Budget 2021-22, Speech of Nirmala Seetharaman, Minister of Finance. Retrieved from Government of India: www.indiabudget.gov.in/doc/Budget_ Speech.pdf

26. PFC. (2020). Report on Performance of State Power Utilities 2018-19. Retrieved from Power Finance Corporation: www.pfcindia.com/DocumentRepository/ckfinder/files/ Operations/Performance_Reports_of_State_Power_Utilities/Report\%20on\%20 Performance\%20of\%20State\%2OPower\%2OUtilities\%202018-19.pdf

27. Ministry of Power, 2021. Ranking \& Ninth Annual Integrated Rating of State Power Distribution Utilities. Retrieved from https://pfcindia.com/DocumentRepository/ ckfinder/files/Gol_Initiatives/Annual_Integrated_Ratings_of_State_DISCOMs/9th\%20 Integrated\%2ORating\%2OBooklet.pdf

28. CEA. (2020, November). Executive Summary. Retrieved from Central Electricity Authority: www.cea.nic.in/wp-content/uploads/installed/2020/11/installed_capacity.pdf

29. Foster, Vivien, and Anshul Rana. 2020. Rethinking Power Sector Reform in the Developing World. Sustainable Infrastructure Series. Washington, DC: World Bank. doi:10.1596/9781-4648-1442-6. Retrieved from https://openknowledge.worldbank.org/bitstream/handl e/10986/32335/9781464814426.pdf?sequence=10\&isAllowed=y

30. Chitnis, A., Dharmadhikary, S., Dixit, S., Dukkipati, S., Gambhir, A., Josey, A., ... Sreenivas, A. (2018). Many Sparks but Little Light: The Rhetoric and Practice of Electricity Sector Reforms in India. Pune: Prayas (Energy Group).

31. Ibid

32. The Economic Times. 2020. 15 Lakh Govt Officials to Boycott Work against Privatisation of UP Power Discom. October 5. www.energy.economictimes.indiatimes.com/news/ power/15-lakh-govt-officials-to-boycott-work-tomorrow-against-privatisation-of-uppower-discom/78484710

33. Kaladharan, Megha. 2017. "Wielding Power in the Capital: The Case of the Delhi Electricity Distribution Sector." Mapping Power Project: Centre for Policy Research and Regulatory Assistance Project. https://www.raponline.org/wp-content/uploads/2017/04/rap-india-mappingpower-delhi-2017-april2.pdf

34. Economic Times, February 3, 2021. Will delicense discoms to end monopolies: Singh. Retrieved from: www.pressreader.com/india/the-economictimes/20210204/282136409093344/textview 
35. World Bank, 2018. Private versus public electricity distribution utilities: Are outcomes different for end-users?. Retrieved from https://blogs.worldbank.org/developmenttalk/ private-versus-public-electricity-distribution-utilities-are-outcomes-different-end-users

36. Economics Times, 2020. Is privatization a panacea for reforming DISCOMs? Retrieved from https://economictimes.indiatimes.com/industry/energy/power/is-privatization-a-panacea-for-reforming-discoms/articleshow/78911020.cms?from $=\mathrm{mdr}$

37. Pargal, S., \& Banerjee, S. G. (2014). More Power to India - The Challenge of Electricity Distribution. Washington D.C.: The World Bank.

38. Ibid

39. Appunn, K., \& Russell, R. (2015, January 12). German utilities and the Energiewende. Retrieved from Clean Energy Wire: www.cleanenergywire.org/factsheets/german-utilities-and-energiewende

40. Wagner, O., \& Berlo, K. (2017). Remunicipalisation and Foundation of Municipal Utilities in the German Energy Sector: Details about Newly Established Enterprises. Journal of Sustainable Development of Energy, Water and Environment Systems, 396-407. Retrieved from Journal of Sustainable Development of Energy, Water and Environment Systems.

41. Thakur, T., Bag, B., \& Prakash, S. (2017). A critical review of the franchisee model in the electricity distribution sector in India. The Electricity Journal, 15-21.

42. PowerLine, 2019. Revisiting DFs - MoP focuses on franchise model to improve operations. Retrieved from PowerLine: www.powerline.net.in/2019/10/05/revisiting-dfs/

43. Srivastava, V, 2019. Feedback Infra's distribution arm to bid for MP, Tripura, Rajasthan rural electricity distribution areas. Retrieved from Financial Express: www.financialexpress. com/economy/feedback-infras-distribution-arm-to-bid-for-mp-tripura-rajasthan-rural-electricity-distribution-areas/1775161/

44. PowerLine, 2017. FEDCO - Delivering results as a distribution franchisee. Retrieved from PowerLine: www.powerline.net.in/2017/07/10/fedco/

45. Ibid

46. India Power Factor, 2017. Making the distribution franchisee model work. Retrieved from India Power Factor: www.indiapowerfactor.in/making-distribution-franchisee-model-work/

47. Chitnis, A., Dharmadhikary, S., Dixit, S., Dukkipati, S., Gambhir, A., Josey, A., .. Sreenivas, A. (2018). Many Sparks but Little Light: The Rhetoric and Practice of Electricity Sector Reforms in India. Pune: Prayas (Energy Group).

48. Pillai, V, 2018. India Needs More Distribution Franchisees: Essel Utilities. Retrieved from T\&D India: www.tndindia.com/india-needs-distribution-franchisees-essel-utilities/

49. Prayas (Energy Group), 2009. Review of the Distribution Franchisee model implemented by MSEDCL in the Bhiwandi circle. Retrieved from www.prayaspune.org/peg/media/k2/ attachments/bhiwandi_review_rpt_102A01.pdf

50. APERC, 2018. POWER PURCHASE RATE DETERMINATION FOR RESCOS DURING FY2018-19. Retrieved from ANDHRA PRADESH ELECTRICITY REGULATORY COMMISSION: www.aperc.gov.in/admin/upload/rescoorderfy201819.pdf 
51. Patankar, M., Weston, F., Sliger, J., Shendage, P., \& Lieberman, R. (2020, May). Cooperative Governance: Opportunities to Enhance Rural Livelihoods in India. Retrieved from Regulatory Assistance Project (RAP): www.raponline.org/wp-content/ uploads/2020/05/RAP-IN_Alternative-Governance-Policy-Brief-5-2020-1.pdf

52. SPI. (n.d.). Model Distribution Zone (MDZ) Program Odisha. Retrieved from Smart Power India: www.smartpowerindia.org/pdf/SPI\%2OReport\%2OFINAL_MDZ.pdf

53. SPI. (n.d.). How Odisha's 200 bijulee didis are ensuring uninterrupted electricity to rural areas. Retrieved from Smart Power India: www.smartpowerindia.org/odisha-bijulee-didis-rural-electricity-power

54. MoP. 2020. "Draft Standard Bidding Documents for Privatization of Distribution Licensees." Ministry of Power, Government of India. https://powermin.nic.in/sites/default/ files/webform/notices/20200922_Draft_SBD_for_privatisation_of_Distribution_ Licensees.pdf.

55. Tata Power, 2021. Tata Power receives Lol to operate the power distribution system in Northeastern part of Odisha. Retrieved from: www.tatapower.com/media/ PressReleaseDetails/1834/tata-power-receives-loi-to-operate-the-power-distributionsystem-in-north-eastern-part-of-odisha

56. Economic Times, February 3, 2021. Will delicense discoms to end monopolies: Singh. Retrieved from: www.pressreader.com/india/the-economictimes/20210204/282136409093344/textview

57. Tejal Kanitkar, Nikhil Thejesh, Upasna Ranjan, 2019. Cost of avoided carbon: Optimizing power supply in southern India, Energy Policy, Volume 149

58. Pargal, S., \& Banerjee, S. G, 2014. More Power to India - The Challenge of Electricity Distribution. Washington D.C.: The World Bank.

59. Soumya Deep Das, R. Srikanth, 2020. Viability of power distribution in India - Challenges and Way Forward, Energy Policy, Volume 147

60. Garg, V., \& Shah, K. (2020, August). The Curious Case of India's Discoms: How Renewable Energy Could Reduce Their Financial Distress. Retrieved from IEEFA: www.ieefa.org/ wp-content/uploads/2020/08/The-Curious-Case-of-Indias-Discoms_August-2020.pdf

61. Rawat, V. S. (2019, July 19). Setback for thermal units as UP energy watchdog bans new PPAs till Dec 2022. Retrieved from Business Standard: www.business-standard.com/ article/economy-policy/setback-for-thermal-units-as-up-energy-watchdog-bans-newppas-till-dec-2022-119071200633_1.html

62. CEEW, 2020. Streamlining open access - an alternative to scaling renewables in India? Retrieved from https://cef.ceew.in/masterclass/analysis/streamlining-open-access-alternative-to-scaling-renewables-in-india.

63. Business Standard, 2021. Govt proposes Rs 3.05 trn scheme to revive power distribution companies. Retrieved from www.business-standard.com/budget/article/govt-proposes-rs-3-05-trn-scheme-to-revive-power-distribution-companies-121020101139_1.html

64. Chitnis, Ashwini, and Saumya Vaishnava. 2017. "In the Name of Competition: The annals of 'cost-plus competition' in the electricity sector in Mumbai" Retrieved from www. prayaspune.org/peg/publications/item/333-in-the-name-of-competition-the-annalsof-cost-plus-competition-in-the-electricity-sector-in-mumbai.html 
65. Business Insider, 2021. You will be able to swap your power distributor, but you might have to pay to port. Retrieved from www.businessinsider.in/business/corporates/news/ you-will-be-able-to-swap-your-power-distributor-but-you-might-have-to-pay-to-port/ articleshow/80648786.cms

66. Chitnis, Ashwini, and Saumya Vaishnava. 2017. "In the Name of Competition: The annals of 'cost-plus competition' in the electricity sector in Mumbai" Retrieved from www. prayaspune.org/peg/publications/item/333-in-the-name-of-competition-the-annalsof-cost-plus-competition-in-the-electricity-sector-in-mumbai.html

67 Pargal, S., \& Banerjee, S. G, 2014. More Power to India - The Challenge of Electricity Distribution. Washington D.C.: The World Bank. Retrieved from https://openknowledge. worldbank.org/bitstream/handle/10986/18726/889060PUB0978100Box385252BOOPUBLICO.pdf? sequence=1\&isAllowed=y

68 Ibid

69 J.T. Huenteler, D.J. Hankinson, N. Rosenthal, A. Balabanyan, A. Kochnakyan, T.C. Nguyen, A. Rana, V. Foster, Cost Recovery and Financial Viability of the Power Sector in Developing Countries: Insights from 15 Case Studies, The World Bank, 2020. Retrieved from: http://documents1.worldbank.org/curated/en/970281580414567801/pdf/Cost-Recovery-and-Financial-Viability-of-the-Power-Sector-in-Developing-Countries-Insights-from-15-Case-Studies.pdf

70 Josey, A., Mandal, M., \& Dixit, S. (2017, November). The lesser-known tariff - Fuel surcharge levy in Indian States. Retrieved from Prayas Energy Group: https://www.prayaspune. org/peg/publications/item/365-the-lesser-known-tariff-fuel-surcharge-levy-in-indianstates.html

71 Economics Times, 2014. Improve discoms' health to attract investments in power: World Bank. Retrieved from https://economictimes.indiatimes.com/industry/energy/ power/improve-discoms-health-to-attract-investments-in-power-world-bank/articleshow/37120280.cms?from $=\mathrm{mdr}$

72 Money Control, 2020. Regulatory assets of discoms may touch ₹90,000 crore if economy stalls for another 4 months: Expert. Retrieved from www.moneycontrol.com/news/ business/regulatory-assets-of-discoms-may-touch-rs-90000-crore-if-economy-stallsfor-another-4-months-expert-5253141.html

73 Economics Times, 2019. Delhi discoms regulatory assets down by ₹3,029 cr in 5 years. Retrieved from https://energy.economictimes.indiatimes.com/news/power/delhi-discoms-regulatory-assets-down-by-rs-3029-cr-in-5-years/71037619

74 JPAL. (n.d.). Reforming agriculture: When power is worth saving. Retrieved from Poverty Action Lab: www.povertyactionlab.org/sites/default/files/2019.01.04-JPAL.SA-ThelndianExpress.pdf

75 Soumya Deep Das, R. Srikanth, 2020. Viability of power distribution in India - Challenges and Way Forward, Energy Policy, Volume 147

76 Forum of Regulators, 2021. Report on Analysis of Factors Impacting Retail Tariff and Measures to Address Them. Retrieved from: www.forumofregulators.gov.in/Data/Reports/ REPORT\%20ON\%2OANALYSIS\%200F\%2OFACTORS\%2OIMPACTING\%2ORETAIL\%2O TARIFF\%2OAND\%2OMEASURES\%2OTO\%2OADDRESS\%2OTHEM.pdf 
77 Bhatnagar, N, 2020. Shift in Strategy - Discoms look for greater flexibility in power procurement. Retrieved from PowerLine: www.powerline.net.in/2020/09/11/shift-in-strategy/

78 Indian Energy Exchange, n.d. Retrieved from Indian Energy Exchange: www.iexindia. $\mathrm{com} /$

79 Gupta, U, 2020. Green term-ahead trading records 151\% growth. Retrieved from PV Magazine: www.pv-magazine-india.com/2020/11/04/green-term-ahead-trading-records-151growth/

80 CERC, 2018. Discussion Paper on Market Based Economic Dispatch of Electricity: Re-designing of Day-ahead Market (DAM) in India. Retrieved from Central Electricity Regulatory CommissionC: www.cercind.gov.in/2018/draft_reg/DP31.pdf

81 New Indian Express. 24 May 2021. "'AP model' saves Rs 2,342 crore in power expenses in last two years" Retrieved from https://www.newindianexpress.com/states/andhrapradesh/2021/may/24/ap-model-saves-rs-2342-crore-in-power-expenses-in-last-twoyears-2306746.html

82 Shyam Sundar R, Harikrishna Muda, M A V Krishnan, R. Srikanth. 2021. An Integrated Approach to Development and Environment in the Power Sector. Retrieved from hwww.researchgate.net/publication/350431757_an_Integrated_Approach_to_Development_and_Environment_in_the_Power_Sector

83 Daljit Singh and Ashwini K Swain, 2018. Fixated on Megawatts: Urgent Need to Improve Power Procurement and Resource Planning by Distribution Companies in India. Retrieved from: www.cprindia.org/system/tdf/policy-briefs/CEER\%2O(2018)\%20 Fixated\%20on\%2OMegawatts_Urgent\%2ONeed\%2Oto\%2OImprove\%2OPower\%2OProcurement\%20and\%2OResource\%2OPlanning\%2Oby\%2ODistribution\%20Companies\%20 in\%2OIndia.pdf?file=1\&type=node\&id=8968\&force=1

84 NSGM, 2019. Impact Assessment of Smart Grid Pilot Projects Deployed in India. Retrieved from National Smart Grid Mission: www.nsgm.gov.in/sites/default/files/SGPP_ Impact_Assessment_Findings_by_QCl.pdf

85 EESL, 2020. National Smart Meter Program Dashboard. Retrieved from Enery Efficiency Services Limited: www.smnp.eeslindia.org/

86 Mittal, R., Saraswat, K., Gupta, A., \& Gaba, K. M, 2016. Lighting the Way - Manipur: Post Unbundling Reform in Distriution. Retrieved from The World Bank Group: www. openknowledge.worldbank.org/bitstream/handle/10986/24970/LightingOtheOwOormsOinOdistribution.pdf?sequence=1\&isAllowed $=\mathrm{y}$

87 Jai, Shreya. 1 15t February 2021. "Budget 2021: Power discoms get second chance, ₹ 3.05 trillion for reforms". Business Standard. Retrieved from www.business-standard.com/ budget/article/budget-2021-power-discoms-get-second-chance-rs-3-05-trillion-for-reforms-121020100568_1.html

88 NSGM, 2020. Smart Grid Definition. Retrieved from: https://www.nsgm.gov.in/en/ smart-grid\#: : :text=Definition,time\%20or\%20near\%20real\%20time.

89 Hindustan Times, 2019. Delhi discoms losing ₹150 crore annually to power theft by e-rickshaws: Sources. Retrieved from www.hindustantimes.com/delhi-news/delhi-dis- 
coms-losing-rs-150-crore-annually-to-power-theft-by-e-rickshaws-sources/story-QojtMIWUIZGLd23GTDKaHP.html

90 Economic Times 2016. Report power theft and get reward in Haryana. Retrieved from https://energy.economictimes.indiatimes.com/news/power/report-power-theft-andget-reward-in-haryana/55885822

91 Economics times, 2016. 11 new police stations to curb power theft in state. Retrieved from https://energy.economictimes.indiatimes.com/news/power/11-new-police-stationsto-curb-power-theft-in-gujarat/55323527

92 Mittal, R., Saraswat, K., Gupta, A., \& Gaba, K. M, 2016. Lighting the Way - Manipur: Post Unbundling Reform in Distriution. Retrieved from The World Bank Group: www. openknowledge.worldbank.org/bitstream/handle/10986/24970/LightingOtheOwOormsOinOdistribution. .pdf? sequence $=1$ \&isAllowed $=y$

93 Livemint, 2020. Centre weighs EMI scheme for state govt depts to clear power dues. Retrieved from www.livemint.com/industry/energy/centre-weighs-emi-scheme-for-stategovt-depts-to-clear-power-dues-11580149758395.html

94 Khadilkar, S. (n.d.). Tata Power Demand Response Program. Retrieved from BEE India: www.beeindia.gov.in/sites/default/files/ctools/Shekhar\%2OKhadilkar\%20Tata\%20 Power\%2ODR.pdf

95 The Hindu, January 23, 2019. Bescom maps out summer plan for smooth supply. Retrieved from: www.thehindu.com/news/cities/bangalore/bescom-maps-out-summerplan-for-smooth-supply/article26072148.ece

96 AEEE, Oracle. (2019). Behavioural Energy Efficiency Potential for India. Retrieved from Oracle: www.oracle.com/a/ocom/docs/industries/utilities/behavioural-energy-efficiency-wp.pdf

97 Ibid

98 Nidhi Bali, Sidhartha Vermani, Vaishali Mishra 2020 Electricity Access and Benchmarking of distribution utilities in India, New Delhi: Smart Power India-powered by The Rockefeller Foundation

99 Gandhi, Vimlesh B. 2017. "Presentation on AT\&C Loss". Retrieved from: www.uday.gov.in/ images/at_loss_workshop_sept2017/Mr_VB_Gandhi_from_MGVCL_Gujarat_on_Best_ Practices.pdf

100 Singh, Sudheer. February 1, 2020. "Budget 2020: Major focus on PM KUSUM scheme to help farmers generate income from solar power". Retrieved from: https://energy. economictimes.indiatimes.com/news/renewable/budget-2020-major-focus-on-pm-kusum-scheme-to-help-farmers-generate-income-from-solar-power/73832492

101 Richa Mishra. December 12, 2020. PM-KUSUM will shine when implemented fully. www. thehindubusinessline.com/opinion/columns/pm-kusum-will-shine-when-implementedfully/article33309349.ece

102 R. Srikanth, 2018. India's sustainable development goals - Glide path for India's power sector, Energy Policy. Volume 123, pp 325-336

103 Soumya Deep Das, R. Srikanth, 2020. Viability of power distribution in India - Challenges and Way Forward, Energy Policy, Volume 147 
104 IEA, 2021. Renewables Integration in India, IEA, Paris. Retrieved from: https://www.iea.org/reports/renewables-integration-in-india

105 PGCIL, 2012. Green Energy Corridor Report. Retrieved from Power Grid Corporation of Indi: www.powergridindia.com/green-energy-corridor-report

106 Kesavan, S, 2020. Transmission Update: Ramping up to integrate renewables. Retrieved from PowerLine: www.powerline.net.in/2020/09/14/transmission-update-2/

107 CEA, 2020. Installed Capacity Report. Retreived from Central Electricity Authority: www. cea.nic.in/wp-content/uploads/installed/2020/11/installed_capacity.pdf

108 Tejal Kanitkar, Nikhil Thejesh, Upasna Ranjan, 2019. Cost of avoided carbon: Optimizing power supply in southern India, Energy Policy, Volume 149

109 Twesh Mishra. July 7, 2020. Renewable Purchase Obligation compliance remains low in most States. The Hindu Businessline. Retrieved from: www.thehindubusinessline.com/ economy/renewable-purchase-obligation-compliance-remains-low-in-most-states/article32002527.ece

110 Tejal Kanitkar, Nikhil Thejesh, Upasna Ranjan, 2019. Cost of avoided carbon: Optimizing power supply in southern India, Energy Policy, Volume 149

111 GIZ, 2017. Large Scale Integration of Renewable Energy. Retrieved from https://tuewas-asia.org/wp-content/uploads/2017/05/15-GIZ_Summary-Report.pdf

112 MNRE, 2019. SARAL - State Rooftop Solar Attractiveness Index. New Delhi. Retrieved from www.solarrooftop.gov.in/notification/Notification-30082019-161516.pdf

113 Jaffer, H, 2017. MINIGRIDS (India) - Current Challenges and Future Strategies. Retrieved from Selco Foundation: www.selcofoundation.org/wp-content/uploads/2017/O4/IAP_ MinigridsIndiaReportTATA_Huda.pdf

114 REEEP, 2017. Scale and Sustainability - Toward a Public-Private Paradigm in Powering India. Retrieved from Renewable Energy and Energy Efficiency Partnership (REEEP): www.reeep.org/sites/default/files/Scale_and_Sustainability_PowerInIndia_ForScreens. pdf

115 Nidhi Bali, Sidhartha Vermani, Vaishali Mishra 2020 Electricity Access and Benchmarking of distribution utilities in India, New Delhi: Smart Power India-powered by The Rockefeller Foundation

116 SPI, ISEP, 2019. Rural Electrification India - Customer Behaviour and Demand. Retrieved from Smart Power India: www.smartpowerindia.org/media/1230/report_rural-electrification-in-india_customer-behaviour-and-demand.pdf

117 SEforAll, BNEF, MGP, 2020. State of the Global Mini-grids Market Report 2020. Retrieved from SEforAll: www.seforall.org/system/files/2020-06/MGP-2020-SEforALL.pdf

118 Ibid

119 Alliance Magazine, 2011. Why are they funding Husk Power? Retrieved July 09, 2020, from Alliance Magazine: www.alliancemagazine.org/feature/why-are-they-fundinghusk-power/

120 Husk Power Systems, n.d. Husk Power Systems. Retrieved July 2020, 10, from: www. huskpowersystems.com/ 
121 CEEW, 2018. Access to Clean Cooking Energy and Electricity - Survey of States 2018. Retrieved from www.ceew.in/publications/access-clean-cooking-energy-and-electricity

122 Bhattacharyya, S. C, 2014. Viability of off-grid electricity supply using rice husk: A case study from South Asia.

123 CSE, 2016. Minigrids: Electricity for all. New Delhi: Centre for Science and Environment. Retrieved from www.cdn.cseindia.org/userfiles/mini-grids.pdf

124 CEA, 2020. Report on Optimal Generation Capacity Mix For 2029-30. Retrieved from https://cea.nic.in/wp-content/uploads/irp/2020/12/Optimal_mix_report_2029-30_FINAL.pdf

125 Tata Power, 2019. Tata Power Collaborates with AES and Mitsubishi Corporation to Power Up South Asia's Largest Grid-Scale Energy Storage System in India. Retrieved from Tata Power: www.tatapower.com/media/PressReleaseDetails/1617/tata-power-collaborates-with-aes-and-mitsubishi-corporation-to-power-up-south-asias-largest-grid-scaleenergy-storage-system-in-india

126 Mahesh.M, D. T, 2019. Study of different use cases of the grid connected Battery Energy Storage System in India. Retrieved from Greening the Grid (GTG) Program: https://regridintegrationindia.org/wp-content/uploads/sites/14/2019/12/6B_4_RE_India19_140_ presentation_Ram_Krishan.pdf

127 USAID, n.d.. Grid Integration Pilots. Retrieved from USAID: www.gtg-india.com/grid-integration-pilots/

128 TERI, 2015. PPP in Electricity Distribution: Case Studies of Delhi and Odisha. Retrieved from TERI: www.teriin.org/eventdocs/files/TERI-GSEP-PPP-in-Electricity-Distribution_ Case-Studies.pdf

129 PGVCL, 2019. 15th Annual Report 2017-18. Retrieved from Paschim Gujarat Vij Company Limited: www.pgvcl.com/about\%20us/ACCOUNT/Aannual\%20Account\%2020172018R2.pdf

130 The Greater India, 2020. Is privatization a panacea for reforming DISCOMs?. Retrieved from https://thegreaterindia.in/news/business/is-privatization-a-panacea-for-reforming-discoms/

131 Tata Power, 2020. Tata Power to manage power distribution in Central Odisha from 1st June onwards Retrieved from: www.tatapower.com/media/PressReleaseDetails/1784/ tata-power-to-manage-power-distribution-in-central-odisha-from-1st-june-onwards

132 Business Standard, 2020. UP govt rolls back decision to privatise power distribution companies. Retrieved from www.business-standard.com/article/economy-policy/up-govt-rolls-back-decision-to-privatise-power-distribution-companies-120100601627_1.html

133 Tata Power - DDL. (n.d.). A Decade of Excellence (2002 - 2012). Retrieved from Tata Power: $\quad$ www.tatapower-ddl.com/Editor_UploadedDocuments/Content/TPDDL\%20 Case\%20Study_COMPLETION\%200F\%2010\%20YRS.pdf

134 Kapoor, S, 2020. Discom Improvement in Haryana. (J. Ningthoujam, Interviewer)

135 Gayatri, G, 2020. State Discoms put up top show - UHBVN and DHBVN are now in the 
league of 'top performers' in the country. Retrieved from The Tribune: www.tribuneindia. com/news/haryana/state-Discoms-put-up-top-show-28352

136 BEE, 2017. First Prize - Electricity Distribution Companies (DISCOMS): EASTERN POWER DISTRIBUTION COMPANY OF A.P LIMITED Visakhapatnam (Andhra Pradesh). Retrieved from Knowledge Exchange Platform: www.knowledgeplatform.in/wp-content/ uploads/2017/02/11.-Electricity-Distribution-Companies.pdf

137 Dubash, N. K., Kale, S. S., \& Bharvirkar, R. (2018). Mapping Power: The Political Economy of Electricity in India's States. New Delhi: Oxford University Press.

138 Mittal, R., Saraswat, K., Gupta, A., \& Gaba, K. M. (2016, February). Lighting the Way - Manipur: Post Unbundling Reform in Distriution. Retrieved from The World Bank Group: www. openknowledge.worldbank.org/bitstream/handle/10986/24970/LightingOtheOwOormsOinOdistribution.pdf?sequence=1\&isAllowed=y

139 TERI. (2015). PPP in Electricity Distribution: Case Studies of Delhi and Odisha. Retrieved from TERI: www.teriin.org/eventdocs/files/TERI-GSEP-PPP-in-Electricity-Distribution_ Case-Studies.pdf

140 PFC. (2020). Report on Performance of State Power Utilities 2018-19. Retrieved from Power Finance Corporation: www.pfcindia.com/Home/VS/29

141 Ibid

142 Ibid 
Designed by 